University of Louisville

ThinkIR: The University of Louisville's Institutional Repository

Electronic Theses and Dissertations

$5-2005$

\title{
Child of the North : Louisville's transition to a southern city,
} 1879-1885.

Robert Bruce Symon Jr., 1962-

University of Louisville

Follow this and additional works at: https://ir.library.louisville.edu/etd

\section{Recommended Citation}

Symon, Robert Bruce Jr., 1962-, "Child of the North : Louisville's transition to a southern city, 1879-1885." (2005). Electronic Theses and Dissertations. Paper 1412.

https://doi.org/10.18297/etd/1412

This Master's Thesis is brought to you for free and open access by ThinkIR: The University of Louisville's Institutional Repository. It has been accepted for inclusion in Electronic Theses and Dissertations by an authorized administrator of ThinkIR: The University of Louisville's Institutional Repository. This title appears here courtesy of the author, who has retained all other copyrights. For more information, please contact thinkir@louisville.edu. 


\title{
“CHILD OF THE NORTH”: LOUISVILLE'S TRANSITION TO A SOUTHERN CITY, 1879-1885
}

\author{
By \\ Robert Bruce Symon, Jr. \\ B.S., The Florida State University, 1991 \\ B.J., The University of Texas at Austin, 1984
}

\author{
A Thesis \\ Submitted to the Faculty of the \\ Graduate School of the University of Louisville \\ In Partial Fulfillment of the Requirements \\ For the Degree of
}

Master of Arts

Department of History

University of Louisville

Louisville, Kentucky

May 2005 
“Child Of The North”: Louisville’s Transition To A Southern City, 1879-1885

By

Robert Bruce Symon, Jr.

B.S., The Florida State University, 1991

B.J., The University of Texas at Austin, 1984

A Thesis Approved On

April 6, 2005

By the following Thesis Committee:

Thesis Director 


\section{DEDICATION}

This thesis is dedicated to my parents

Robert and Langston Symon

who provided the wherewithal and encouragement to

pursue and achieve my dreams 


\section{ACKNOWLEDGEMENTS}

I would like to thank Dr. Thomas Mackey, my thesis advisor, for his wisdom and guidance. Without his tutelage, my development in the historical academic arena would surely have been inhibited. Not only did he make me a better student, but also a better man. Any success I have achieved or will achieve in the future regarding this academic pursuit will be due to his diligence and patience. I will forever be indebted to him and will forever regard him as my friend. I appreciate the effort, valuable insight and suggestions of Dr. Benjamin Harrison and Dr. Jasmine Farrier for the preparation of the final draft of this thesis. My work would not have been possible without the generosity of Mr. James J. Carter, WLKY-TV General Manager, Michael L. Neelly, WLKY-TV News Director, and Jay A. Cardosi, WLKY-TV Chief Meteorologist. I would be remiss if I did not acknowledge the valuable assistance of the staff at the Filson Historical Society and the Louisville Free Public Library. My particular gratitude goes out to Louisville Free Public Library Librarian Assistant Sue Ann Wight. My wife, Cassie, deserves all my love and appreciation for her support and patience through many long nights. Finally, I want to thank Robert and Langston Symon, my parents, who have helped me when I have fallen, loved me when I failed, and encouraged me to pursue my dreams. 


\author{
ABSTRACT \\ "CHILD OF THE NORTH": LOUISVILLE'S TRANSITION TO \\ A SOUTHERN CITY, 1879-1885 \\ Robert B. Symon, Jr. \\ April 16, 2005
}

This thesis is a historical examination of the perception of Louisville as a southern city. The work begins with a discussion regarding Louisville's historical ties with the North and its acceptance as either a western or northern city. The thesis then shifts into examining the details of the events surrounding the deliberate attempt of city leaders to define Louisville as a southern city in an effort to exploit southern markets following the Civil War. The thesis points to August 3,1883 as the day of the transition and frames the transition period around the visit of former President and ex-Union General Ulysses S. Grant to Louisville in 1879 and a birthday celebration for Grant in Louisville in 1885 .

The thesis is divided into five chapters. The Introduction outlines Louisville's history and develops the historiography regarding the topic. Chapter One develops Louisville's historical ties with the North and provides a glimpse into societal, economic and political atmosphere of nineteenth century Louisville. Chapter Two details the 1872 Grand National Industrial Exposition of Louisville, the visit of Ulysses S. Grant to Louisville in 1879 and Louisville's 1883 Southern Exposition. Chapter Three is dedicated to the sixty-third birthday celebration of 
Ulysses S. Grant in Louisville in 1885. The Conclusion reviews the overall process of the transition of the perception of Louisville as a southern city while reasserting that the transition came about due to a conscious effort on the part of Louisville business and political leaders. 


\section{TABLE OF CONTENTS}

PAGE

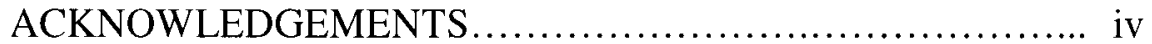

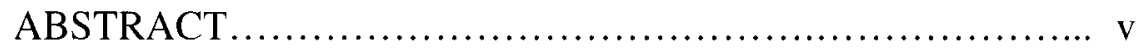

INTRODUCTION......................................

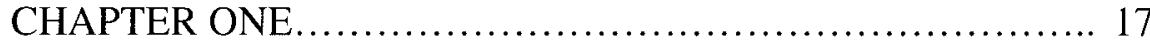

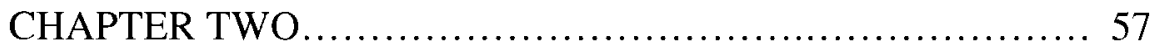

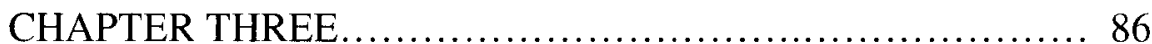

CONCLUSION.......................................... 109

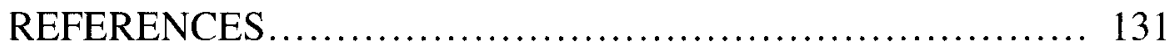

CURRICULUM VITAE..................................... 139 


\section{INTRODUCTION}

When General Grant visited Louisville on December 11, 1879, the gates of the city were thrown open in royal welcome to the distinguished guest. People of Louisville endeavored to outdo one another in trying to honor and please the former President. The entertainment arranged surpassed anything before seen in this city. ${ }^{I}$

Louisville Herald, April 27, 1923.

Given Louisville's supposed pro-southern history, it might be considered remarkable that former President and Union Army Commander Ulysses S. Grant found full acceptance in the Falls City. Yet, Louisville's welcome to Grant should not come as a surprise. Louisville's roots lie in the original thirteen colonies. The Ohio River marked the western frontier of the Virginia Colony and linked the developing West and East Coast markets. Militarily, the river also held strategic value in the colonist's fight against the Native Americans and British in the American Revolution. In 1778, George Rogers Clark established a fort at the Louisville settlement due to the geological formation known as the Falls of the Ohio, which served as an impediment to river traffic and also formed the only natural bridge across the river. In times of low water, commerce unloaded at the 
head of the Falls before reloading below the Falls in order to continue.

Consequently, Louisville grew as a port of exchange and trade. The necessity of transfer tied Louisville to the Northern economic centers and increased the city's importance to trade between established east coast cities and the expanding frontier. In 1855, the federal government became the chief financier of a canal around the Falls to facilitate a more rapid passage of goods. Railroads from the North recognized Louisville as an ideal location for a transfer point between East and West, North and South and a number of rail lines, including the Louisville and Nashville and later the Pennsylvania and Chesapeake and Ohio, had connections with the city. In the Civil War, the Union Army based its Army of the Ohio in Louisville because of its strategic location for distribution of communications and supplies to armies in the field. From the time of Louisville's founding through the Civil War, economic livelihood linked Louisville with the East and Great Lakes states. Nevertheless, modern perceptions that Louisvillians considered U.S. Grant as little better than an ogre are probably more common than the historical perception and contradict Louisville's warm welcome for the man in 1879.

By the late nineteenth century, Louisville had come to be known as a southern city and Louisvillians considered themselves southern and the city a southern metropolis. The thesis of this work is that political and business leaders altered the perception of Louisville from its traditional view of itself as a northern city to that of a southern city in an effort to strengthen economic ties with southern

1 “Grant's Visit Here Recalled," The Louisville Herald. 27 April 1923. 
markets. This transformation began following the Civil War and became a public reality with the opening of the Southern Industrial Exposition in Louisville in 1883. This study frames the transition time for this change in self-perception between the visit of former President Ulysses S. Grant to Louisville in 1879 and the 1885 celebration of his birthday by Louisville's elites.

Given the monumental shift in perception and the effort put forth by Louisvillians to change the city's image, one might suspect that historians have pursued a thorough examination of the change. Yet, one of the more remarkable aspects of the period in question is the dearth of material on the subject or any concerning the development of Louisville into an industrial city of economic importance. An early comprehensive view of Louisville came in 1882 with the publication of the History of Ohio Falls Cities and Their Counties. ${ }^{2}$ The work had no author or editor listed and the first volume was dedicated to the development of Louisville. The analysis was subdivided into three sections, beginning with a general history of the Falls of the Ohio from the "American Aborigine" and Indians to the appearance of Whites and George Rogers Clark. The first section concluded with the development of the Louisville and Portland Canal, roads, steamships and railroads. The second section dealt with the topography of Jefferson County, its civil organization and military history. The final threequarters of the volume explored the history of Louisville by using subdivisions of twenty-five sections. Ten chronological chapters coincided with the first ten decades of the city and an eleventh chapter elaborated on the then incomplete

\footnotetext{
${ }^{2}$ History of the Ohio Falls Cities and Their Counties Vol. I (Cleveland, OH: L.A. Williams and Co, 1882).
} 
decade of the 1880's. The remainder of the volume addressed many social and municipal subjects such as the development of suburbs, religion, charities, education and libraries. The book also contained a specific overview regarding the evolution of the press, medical profession, judicial system and social clubs. Dispersed throughout the work were 85 brief biographical essays of people deemed by the editors as those of prominence in Louisville's history. Aside from the biographies, the work was largely an antiquarian narrative and appears to have been motivated more by profit than by civic pride as it was published in Cleveland, Ohio. The authors referenced four specific sources and an unnamed "multitude of volumes, pamphlets, newspaper files, oral traditions, and other sources of information." ${ }^{3}$

Perhaps in reaction to outsiders writing their history, Louisvillians produced their own version of the city's history in 1896, the Memorial History of Louisville From Its First Settlement to the Year $1896 .{ }^{4}$ The two-volume set of essays, written by prominent men of the late nineteenth century, covered not only the physical development of Louisville, from settlement to city, but also the political, economic and cultural progress as well. Louisville businessman J. Stoddard Johnston served as editor and included biographical essays on many of the citizens as he stated, "without it the history of the city in its evolution from a hamlet to metropolis would be but half told, since a large part of it is comprised in the record of those who have made it and have stamped it with the impress of

\footnotetext{
3 Ohio Falls Cities, 3.

4 J. Stoddard Johnston, ed., Memorial History of Louisville From Its First Settlement to the Year 1896 Vol. I (Chicago and New York: American Biographical Publishing Company, 1896).
} 
their minds and characters. ${ }^{5}$ Johnston meant the work to be a research tool and includes an extensive table of contents and index. One of the more striking aspects of this compilation of essays was the manner in which it dealt with the Civil War. A chapter, written by Union Captain Thomas Speed, is titled "Civil War History-Federal" while the following entry, by the editor, is called "Civil War History-Confederate." The suggestion that a history of Louisville during the Civil War could not be approached from a singular point of view indicates that, while Louisville remained. loyal and important to the North, southern sympathies had eroded the city's historical link to the past. Because the Memorial History of Louisville had many contributors, it not only offered facts and figures associated with an antiquarian review of Louisville to the end of the nineteenth century, it also provided insight into the thoughts and recollections of individuals from varied, though prominent, walks of life. Many of the authors' formative years fell between 1870 and 1890 and therefore the narrative and commentary of the two decades was particularly detailed. The Memorial History of Louisville has been the basis for most twentieth century analysis of Louisville's history.

In 1939, a University of Louisville graduate student, Leslie S. Wright, advanced a specific aspect of Louisville's history when he addressed the Louisville and Portland Canal. ${ }^{6}$ His effort, The Louisville and Portland Canal, resulted in a largely chronological review of the evolution of the canal from its origins through the end of the canalization project in 1925. Wright's work highlighted the importance of the river to the development of the city and the

\footnotetext{
5 Johntson, Memorial,v.
} 
manner in which improvements to the canal aided in Louisville's growth. This thesis also illustrated the changing utility of the river with the advent of the railroad and industrialization to that of chief transport of bulk materials. The transformation of the river from a carrier of specific goods to bulk raw materials occurred in the 1870 's and 1880 's and Wright traced that development.

The following year, the Louisville Free Public Library used funds from the Federal Emergency Relief Administration to produce a collection of extracts and articles from out of print sources that related to Louisville's history. Library officials produced Collected Writings Relating to the History of Louisville, intending to provide a sense of historical perspective of the city "without an overmeticulous regard for completeness and balance" since such an effort may "retard production."7 Project managers determined that "production results" were "more important than scholarly refinements which would delay, without ever assuring complete satisfaction." 8 Each article and essay provided some insight into the opinions and reflections of a particular time, though footnotes were brief. A number of articles referred to the 1880 's but the academic value was limited, as the specifics provided in any particular essay were not cited. Nonetheless, the work reflected the manner in which Louisville history was, or was not recorded, beyond the Memorial History of Louisville and also indicated the paucity of Louisville history available to the Louisville Free Public Library.

\footnotetext{
${ }^{6}$ Leslie S. Wright, Masters of Arts Thesis, The Louisville and Portland Canal University of Louisville, 1939.

${ }^{7}$ Louisville Library Collections History Series: Collected Writings Relating to the History of Louisville Vol. I (Louisville, KY: The Louisville Free Public Library, 1935), 2. Hereafter cited as Library Collections.

${ }^{8}$ Library Collections, 2.
} 
Railroad development and expansion played a key role in the economic growth and transformation of Louisville. Hence, the 1943 publication of Kincaid Herr's The Louisville and Nashville Railroad provided some valuable background. ${ }^{9}$ The career of Kincaid Herr with the L \& N spanned over forty years, mostly in association with the L\&N Magazine. The work was an in-house history of the railroad which was subsequently revised in 1959, 1960 and finally in 1964. A reprint of the final edition was released to the public in 2000 in commemoration of the 150th anniversary of the railroad's founding. Herr traced the growth of the railroad from its inception in 1850 with particular detail given to the late nineteenth century when the railroad experienced tremendous growth and expansion following the Civil War. The L\&N's era of expansion was not merely coincidental to the growth, expansion and transformation of Louisville and any review of Louisville's history without inclusion of L \& N's history would be incomplete.

By the mid-twentieth century, interest again picked up in examing the history of Louisville. In 1950, The Division of Curriculum and Research of the Louisville Public Schools commissioned Lourena L. Eaton to write a comprehensive review of the city's history for Jefferson County Junior High School students entitled, Louisville in Kentucky. ${ }^{10}$ Only a page was devoted to the 1880 's but the significance of the book rested in its very existence. The lack of historical works beyond the enormous Memorial History of Louisville was evident by the fact the school district felt compelled to produce its own work.

${ }^{9}$ Kincaid Herr, The Louisville and Nashville Railroad: 1850-1963 (Lexington, KY: University of Kentucky Press, 1964). 
The intent of Louisville in Kentucky was to help students understand how the city had grown to its position in 1950.

In 1951, the Commissioners of The Sinking Fund of the City of Louisville commissioned F.E. Wood to write the history of the fund and its effect on the city. After a century of existence, the fund had proved a valuable tool in the growth of Louisville and the local politicians wished to inform the citizens of how the fund had resulted in "a century of fiscal integrity" for the city. Mayor Charles P. Farnsley stated that the commissioners published The Louisville Story: A Report of the Sinking Fund Commission of Louisville not merely for statistics. ${ }^{11}$ The mayor hailed the work as also highlighting "Louisville's early history and struggles to overcome the wilderness; its rapid growth toward the industrial period; and points its future with justifiable pride." ${ }^{12}$ The early pages provided a brief review of Louisville's inception from the time of George Rogers Clark, but it was more useful in reviewing the city's struggle dealing with financing of municipal services for a city that often doubled in size in less than a decade. This work made the case that because of the sinking fund, Louisville avoided debt crisis throughout the century, and did so in spite of numerous economic recessions and depressions that plagued other cities in the nation. Conveniently, the one hundredth anniversary of the fund came shortly after the city imposed a city service fee on the income of all wage earners in the city. Hence, the work can be viewed as a political venture to persuade the citizenry that city leaders

\footnotetext{
${ }^{10}$ Lorena Eaton, Louisville in Kentucky (Louisville, KY: Louisville Public Schools, 1950).

11 F.E. Wood, The Louisville Story: A Report of the Sinking Fund Commission of Louisville (Louisville, KY: City of Louisville, 1951).

${ }^{12}$ Wood, The Louisville Story, 7,9.
} 
actions were but part of the continued tradition communal fiscal responsibility. Nevertheless, it did address the manner, methodology and creativity of civic leaders to deal with unprecedented fiscal pressure put on a city that grew with such rapidity.

In 1954, the Liberty National Bank and Trust Company of Louisville commissioned R.C. Riebel to write Louisville Panorama: A Visual History of Louisville. ${ }^{13}$ The underlying reason for the work was promotional as the bank marked its one hundredth anniversary of operation as "Louisville's Oldest Financial Institution." ${ }^{14}$ However, the text included a listing of the highlights of the eighteenth century, followed by a yearly chronology beginning in 1773 and ending in 1953. Riebel dedicated the final twenty-five pages to bank history, but the previous two hundred pages glimpsed the events surrounding the city's development and carried a number of features on related subjects and people.

Louisvillian Melville O. Briney was inspired by stories told by his father to write a collection of essays called Fond Recollection: Sketches of Old Louisville. With a total publication of just 1000 copies, it is likely that he meant the work as a piece of nostalgia for local residents of Louisville. Briney did not provide any footnotes nor any bibliography to cite the sources of his 47 stories. However, the style of writing and subjects recalled Louisville's past. He subdivided the work into people, places, events as well as a few of his own recollections. In doing so, Briney reiterated the prominence of some of the characters of the last quarter of the nineteenth century. The Jacob and Prather families had residences that took

13 R.C. Riebel, Louisville Panorama: A Visual History of Louisville $2^{\text {nd }}$ ed. (Louisville, KY: Liberty National Bank \& Trust Company, 1956). 
up a city block each on Chestnut Street, which was described by Briney as "the street." One of the Jacob children, Charles D. Jacob, who served as mayor in the 1870 's and 1880 's, rose in politics to become a Democrat state gubernatorial candidate in 1883. The story of "Jacob's Folly," the mayor's controversial purchase of what became known as Iroquois Park, was also related. Along with stories regarding citizens of prominence, Briney's description of events painted a picture of an expanding city of national prestige with visits from the Grand Duke of Russia and P.T. Barnum's Jumbo the Elephant. Briney's story of the Southern Exposition of 1883 captured the excitement of the city for an event that helped to solidify Louisville's moniker of a Southern city. Though academically weak, Fond Recollection provided a nice aesthetic view of nineteenth century Louisville absent of statistics.

The grandson of a corporal in Company D of the First Kentucky Cavalry of the Confederate Army gained inspiration in 1962 to write a history of Louisville during the Civil War. Louisvillian Robert Emmett McDowell answered the call from the Civil War Centennial Commission for Jefferson County to write about the city's history during the "War for Southern Independence." The ironic fact about McDowell's resulting City of Conflict: Louisville in the Civil War 1861$\underline{1865}$ was that the thesis suggested that Louisville had remained a northern city throughout the war. ${ }^{15}$ McDowell dedicated the book to his grandfather, whom he suggested "would have taken violent exception to almost everything in this

\footnotetext{
${ }^{14}$ Riebel, Louisville Panorama, 5.

${ }_{15}$ Robert Emmett McDowell, City of Conflict: Louisville in the Civil War, 1861-1865 (Louisville, KY: Louisville Civil War Roundtable, 1962).
} 
book." ${ }^{\prime 6}$ McDowell acknowledged his reliance on the work of scholars, indicating that McDowell was not a professional academian but more of an enthusiast acting as an editor. The work, steeped in opinion, was fully cited and noted. McDowell argued that Louisville had remained not only loyal to the Union, but that it was also a pro-Union city with the exception of a minority of southern sympathizers. McDowell's viewpoint clashed with the prevailing sentiment of the twentieth century and, in this regard, holds relevance to the historiographical record.

In 1969, University of Louisville Historian Leonard P. Curry published Rail Routes South: Louisville's Fight For The Southern Market, 1865-1872. ${ }^{17}$ The effort was short, but offers valuable insight into the economic aspects of Louisville's transition from a northern industrial city to a southern city. Curry's intention was to "focus on Louisville's efforts to maintain its superior railroad links to the southern market, especially in competition with its nearest rival, Cincinnati." ${ }^{18}$ In detailing the battle between Louisville and Cincinnati over access to southern markets, Curry revealed the political complexities of the railroad business. Political interests interwove with business interests creating a complicated scenario which Curry unraveled. Rail Routes South provided detailed information regarding the competitive nature of the railroad business following the Civil War and the importance of the railroad to Louisville. Although Curry did not attempt to define a specific date for Louisville's

\footnotetext{
${ }^{16}$ McDowell, City of Conflict, ix, dedication.

${ }^{17}$ Leonard P. Curry, Rail Routes South: Louisville's Fight For The Southern Market, 1865-1872 (Lexington, KY: University of Kentucky Press, 1969).

${ }^{18}$ Curry, Rail Routes South, 7.
} 
transition, the work provided the basis for why Louisville business interests worked toward creating a perception of Louisville as a southern city.

A graduate student of History at the University of Louisville focused her attention on the transition of Louisville from 1870 to 1890. In 1970, Charlene M. Cornell referred to the era when "Louisville emerged from a great river town of the past, to become a changing city in a new urban age." Her thesis strayed from much commentary and ventured into local politics. Louisville in Transition: 1870-1890 detailed the shenanigans associated with local elections and the reforms that came about due to charges of corruption, bribery, malfeasance and voter fraud. $^{19}$ In her conclusion, Cornell mentioned Louisville's post-war expansion into southern markets but made no attempt to explain the reasoning nor the impact on the perception of the city. ${ }^{20}$ The essay dealt with the topic in a factual manner with numerous references to newspaper accounts and did little more than recount the history of election reform. Her thesis possessed no strong declarative statement and did not draw conclusions except that election reform laws slowed illegalities in elections and left the populace optimistic for the future. In spite of the limitations of the essay, Cornell provided a good overview of the bitter political rivalries that existed in the two-decade period. Her description of the local political landscape makes the event of April 27, 1885 all the more remarkable.

In the early 1970's, the Kentucky Historical Society proposed a multi-volume history of Kentucky and in 1977 the society produced a four-volume set,

\footnotetext{
${ }^{19}$ Charlene M. Cornell, Master of Arts Thesis, Louisville in Transition: 1870-1890 University of Louisville, 1970.
} 
including Kentucky: Decades of Discord 1865-1900. ${ }^{21}$ From the outset, historians Hambleton Tapp and James C. Klotter acknowledged that the volume's necessity rested in their assertion that "little is known about this important period, perhaps because no in-depth history of it has appeared."22 Though no explanation for the lack of scholarship was offered, Tapp and Klotter supported the notion of a thin historiography of the period including that of Louisville, which stood as the economic hub of the state from the early nineteenth century forward. Like the thesis of Cornell, Tapp and Klotter devoted much of the work to the politics of the time. However, Tapp and Klotter brought particular attention to the influence of Louisvillian Henry Watterson, not only in the political direction of the state, but also in the growth and expansion of Louisville's economy. The struggles within the Democrat Party and the split between the Bourbons and Watterson's New Departure Democrats and both factions relationship with the Republicans indicated a conscious effort to transform Louisville. Instead of belonging to a list of northern industrial cities, Watterson, through his powerful editorials in the Louisville Courier-Journal and his political associates, sought to re-create Louisville as the singular industrial powerhouse of the South. Tapp and Klotter recounted the lobbying in Frankfort to create an economic atmosphere that propelled Louisville to the forefront of southern trade at the expense of cities like Cincinnati. At one point, Watterson joined forces with an unlikely ally, the Republican Party, to force state education and tax reform in an effort to place

${ }^{20}$ Cornell, Louisville in Transition, 139.

${ }^{21}$ Hambleton Tapp and James C. Klotter, Kentucky: Decades of Discord 1865-1900 (Frankfort, KY: The Kentucky Historical Society 1977).

22 Tapp and Klotter, Decades, xiii. 
Louisville and the state in a position to better compete for the southern marketplace. They devoted only one chapter to the agricultural and industrial development of the state, highlighting Louisville as the center of most economic activity. In regard to industrialization, Tapp and Klotter revealed that previous analysis that trumpeted the rapid and extraordinary industrial growth of Louisville neglected the fact that, in comparison to the country as a whole, Louisville's growth did not match the national industrial expansion between 1870 and $1890 .^{23}$ In any event, Decades of Discord, provided a detailed account of the political maneuvering and persuasion that led to the purposeful alteration of Louisville to a southern industrial city.

As was the case following the Memorial History of Louisville, academic analysis of Louisville following Decades of Discord waned. In 1978, Wade Hall, Chairman of the Humanities Division of Bellarmine College, teamed with Nancy Jones, Chairman of the Friends of the Louisville Free Public Library, to publish Louisville 200:Reflections of a City to coincide with the 200th anniversary of Louisville's founding. ${ }^{24}$ It was a compilation of sketches, anecdotes and brief essays dealing with the previous two hundred years. Each passage was noted for the author, time and original publication of the material but the work was largely a condensed version of Collected Writings of 1935 with much of the nostalgia found in Fond Recollections. Also to commemorate Louisville's bicentennial, local historian George H. Yater in 1979 published Two Hundred Years of the

\footnotetext{
23. Tapp and Klotter, Decades, 308-310.

${ }^{24}$ Wade Hall and Nancy Jones, Louisville 200: Reflections of a City (Louisville, KY: Hamilton Printing Co., 1978).
} 
Falls of the Ohio: A History of Louisville and Jefferson County. ${ }^{25}$ A large book

with numerous pictures and illustrations, Yater appealed to the general public with a work lacking in new scholarship, though it did provide a short, antiquarian perspective of Louisville that theretofore was lacking in the public arena since 1896.

A student at the University of Georgia, Anne Elizabeth Marshall, added to the analysis set forth by McDowell's City of Conflict with an academic approach. Her 2000 Master's thesis, Lost Cause: Memory; Identity-The Creation of a Confederate City, was the first scholarly work on the subject since Tapp and Klotter and the first to addresses Louisville's transition from that of a northern city to that of a southern city. ${ }^{26}$ Oddly, she did not pinpoint the time of the transition. Instead, Marshall focused on the activities of the supporters of the "Lost Cause" and outlined the role of southern historians in creating the perception that Louisville was a southern city. Marshall found that the perception of Louisville as a southern city was more myth than reality. However, she did not mention the efforts and motives of Louisvillians to embrace the southern city perception, which in many regards had nothing to do with the "Lost Cause."

Further, autobiographical books by men of prominence such as Thomas Speed and Henry Watterson provided more material for examination of the period of transition for Louisville. The results of their efforts and others to create Louisville's new identity can be narrowed down to a five-year period. Ulysses S.

25 George H. Yater, Two Hundred Years at the Falls of the Ohio: A History of Louisville and Jefferson County $2^{\text {nd }}$ ed. (Louisville, KY: The Filson Historical Society, 1987).

${ }^{26}$ Anne Elizabeth Marshall, Masters of Arts Thesis, Louisville and the Lost Cause: Memory: Identity-The Creation of a Confederate City, University of Georgia, 2000. 
Grant visited Louisville in December 1879. Later, the city organized and promoted a local and national celebration of Grant's birthday on April 27, 1885. In between, Louisville held the Southern Industrial Exposition. While the Southern Exposition has received attention from scholars, absent from the record is analysis or even mention of the years immediately preceding or following its inception. The commemoration in Louisville of Grant's birth triggered a national event, yet, historians have not bothered to footnote the occasion. Grant's visit and Grant's birthday celebration stand as bookends to the period that marked the turning point of Louisville from a Northern industrial also-ran city to that of a prominent southern industrial center. 


\section{CHAPTER ONE}

\section{Louisville's Historical Ties To the North}

The city of Louisville's origin resides in the Falls of the Ohio, a two-mile stretch of rock-strewn rapids with a fall in elevation of 26.5 feet. Captain Thomas Bullitt first surveyed and laid out the town of Louisville in August 1773 at the headwaters of the Falls of the Ohio. In 1778, under secret orders from Virginia Governor Patrick Henry, George Rogers Clark led a military expedition to set up a base of operations for an expected active summer fighting the British and Native Americans on the Western frontier. Clark convinced Henry that, by driving the British from the Illinois Country, Kentucky would be secure from British rule and Native Americans would be persuaded to remain north of the Ohio River. Since every vessel traveling down the Ohio would be compelled to stop at the Falls of the Ohio, Clark reasoned the head of the falls stood as the ideal place for a fort. ${ }^{1}$ The end of Revolutionary War hostilities marked the beginning of Louisville's alliance with northern economic interests as a center of distribution and commerce.

The binding of Louisville to the North can be described on the surface as

${ }^{1}$ George H. Yater, Two Hundred Years at the Falls of the Ohio: A History of Louisville and Jefferson County, $2^{\text {nd }}$ ed. (Louisville: The Filson Club, 1987), 1-4. 
tenuous due Kentucky's status as a slave state. However, closer examination demonstrates that slavery in Kentucky was not completely synonymous with southern states. Jennifer Cole pointed out in her 2004 essay in Ohio Valley History, "For the Sake of the Songs of the Men Made Free: James Speed and the Emancipationists' Dilemma in Nineteenth-century Kentucky," that the process of Kentucky's separation from Virginia in 1792 included a provision that required Kentucky to remain a slave state. In that sense, then, the Virginia legislature forced slavery on Kentuckians. Cole also noted that the minority, yet politically powerful, pro-slavery faction of the Kentucky constitutional conventions of the 1780 's and 1790's included a provision in the state constitution that prohibited the emancipation of slaves without the owner's compensation and consent. ${ }^{2}$ The federal Northwest Ordinance of 1787, prohibiting slavery north of the Ohio River, placed Louisville in an enigmatic position. Free land in the territory known as Indiana, visible from the city, stood closer to Louisville than most of the towns in the state and much of the commerce that entered the city came from that free, northern territory. Furthermore, most of the economy of Kentucky, and particularly Louisville, did not rely on slave labor, as did the southern states.

Historians Amy L. Young and J. Blaine Hudson traced the evolution of slavery in America to labor shortages on tobacco, rice and indigo plantations. ${ }^{3}$ Further development of the agriculture economy in America created an association of plantations with the additional staple crops of sugar, cotton and hemp. However,

\footnotetext{
2 Jennifer Cole, "For the Sake of the Songs of the Men Made Free: James Speed and the Emancipationists' Dilemma in Nineteenth-century Kentucky," Ohio Valley History 4 (Winter 2004); 27-48.
} 
Young and Hudson admit that the only labor intensive cash crops produced in Kentucky in the nineteenth century were tobacco and hemp. ${ }^{4}$ In the instances of hemp and tobacco production in Kentucky, slave requirements were limited. As Young and Hudson have pointed out:

Furthermore, Kentucky tobacco plantations also produced marketable quantities of corn or pork so that adopting a strict task or gang system was not economical. Hemp is a cash crop that is sometimes associated with plantation-style agriculture, but most slaveholdings in Kentucky were involved in a more diversified agriculture of grains and livestock. ${ }^{5}$

In 1794, Thomas Cooper noted that Kentuckians boasted of the quantity of corn the land could produce. Cooper surmised that Kentucky soil yielded three times the corn per acre of other states. ${ }^{6}$ Reuben T. Durrett stated in The Centenary of Kentucky that the Kentucky farmer at the time of statehood planted corn and wheat. He mentioned a typical farmer's garden and livestock for subsistence, but failed to note any production of tobacco or hemp. ${ }^{7}$ Other commentators of early nineteenth century Kentucky also highlighted the corn and grain production in the state similar to the northwestern territory and states. Slave state Kentucky had a political and social association with the South, but the association may be argued as one of perception, though not always a positive

3 Amy L. Young and J. Blaine Hudson, "Slave Life at Oxmoor," The Filson Club History Quarterly 74 (Summer 2000).

4 Young and Hudson, "Slave Life," 206-07.

5 Young and Hudson, "Slave Life," 207.

"Thomas Cooper, "Letters From America to a Friend in England," (1794) Louisville Library Collections History Series: Collected Writings Relating to the History of Louisville Vol I (1935), 114; The publication is a series of reproductions by the Louisville Public Library from "sources not generally available." Hereafter cited as Library Collections.

${ }^{7}$ Reuben T. Durrett, "The Centenary of Kentucky Filson Club Proceedings,"(1892) Library Collections, 98. 
perception. In that regard, Mann Butler in 1834 commented in A History of the

Commonwealth of Kentucky that "would to God Kentucky could always have escaped the curse and the iniquity of their condition." ${ }^{8}$ Henry Bradshaw Fearon explained in the 1818 publication of his American experience that he expected Kentucky to resemble a free state, while he concurrently inferred the true status of Blacks in free states, as he stated:

... although I knew it was a slave State yet having seen so much practical slavery in those States denominated free, I did not anticipate that one in which this deplorable order of things is legalized, could be really worse.

Louisville thrived on the trade of goods and manufacture of materials and slave labor requirements remained limited. In 1818, noted cartographer John Melish said, in Travels in the United States of America, that slavery in Louisville is "against society everywhere." ${ }^{10}$ Cooper, however, implied a labor shortage existed in Louisville and that Louisvillians hired slaves for the jobs required. He argued:

There is scarcely any labour to be hired but that of slaves, let out for the purpose by their owners. These slaves form about one-sixth of the whole number of their inhabitants. ${ }^{11}$

Cooper's narrative not only suggested a lacking need for slave labor in Louisville, but also an abundance of slaves in relation to the population. In 1833, the Kentucky Colonization Society raised two thousand three hundred dollars to book

8 Mann Butler, "A History of the Commonwealth of Kentucky," (1834), Library Collections, 71.

9 Henry Bradshaw Fearon, "Sketches of America-A Narrative of a Journey Through the Eastern and Western States of America," (1818), Library Collections, 134.

${ }^{10}$ John Melish, "Travels in the United States Of America," Library Collections, 128.

11 Cooper, Library Collections, 111. 
passage for 102 free Blacks to Liberia. ${ }^{12}$ Although the true motives for the action cannot be ascertained, the resulting decline of over one hundred Blacks from Louisville society cannot be ignored. Young and Hudson asserted that a feeling of anxiety existed in Louisville, and in Kentucky, that the large number of Blacks, free and slave, might revolt. Owners of uncontrollable slaves often resorted to selling a slave "down the river" to southern plantations. ${ }^{13}$

Though southern cultural perceptions may have prevailed due to slavery, early nineteenth century commentators referred to geographic location of Kentucky and Louisville as West. Frenchman F.A. Michaux said in 1805 that the Ohio River was the center of commerce between the eastern and western states. ${ }^{14}$ Caleb Atwater in 1831 called the character traits of Louisvillians as common to others in the "Western country." ${ }^{15}$ Instead of references to southern cities, citations in the History of the Ohio Falls Cities compared physical features of Louisville and New York, and the character of Louisville women to those of New York, Philadelphia and Baltimore. ${ }^{16}$ Henry Bradshaw Fearon, referenced the South when discussing Louisville, but only in stating that Louisville at the Falls of the Ohio was important for the transport of New Orleans freight to the West. ${ }^{17}$

The impediment of the falls proved to be a boon for Louisville for the identical reason Clark ascertained its military strategic value. The falls forced boats to

\footnotetext{
${ }^{12}$ History of The Ohio Falls and Their Counties Vol I (Cleveland, OH: L.A. Williams and Company, 1882), 274.

13 Young and Hudson, "Slave Life," 196, 218.

${ }^{14}$ F.A. Michaux, "Travels to the Westward of the Allegany Mountains, in the States of Ohio, Kentucky, and Tennessee," (1805), Library Collections, 118.

15 Caleb Atwater, "Remarks Made On a Tour of Prairie du Chien,"(1831), Library Collections, 153.

${ }^{16}$ Ohio Falls History, 163, 165.

17 Fearon, Library Collections, 137.
} 
unload cargo and passengers to disembark at the headwaters then travel over land to another vessel below the falls. The costly, cumbersome and time-consuming endeavor for travelers and shippers proved profitable for Louisville. Warehousing led to a healthy mercantile and manufacturing economy as well as the insurance business. The increased use of the steamboat, expanding agricultural, commercial and military needs of the fledgling country necessitated circumvention of the Falls of the Ohio. ${ }^{18}$ Regional farmers and manufacturers in Cincinnati and Pittsburgh grew frustrated at the inefficiency of moving goods to market due to the time consuming and costly stop required at Louisville. In the early 1820 's, a group of investors from Cincinnati began a project to build a canal around the Falls on the north side of the river. Though the geographic position and geological definition of the Indiana route was economically less desirable than a Kentucky based canal, the project nonetheless began. For years, Louisville city leaders had balked at the prospects of any canal, fearing circumvention of the Falls without an overland transfer would doom the city. However, recognizing the inevitability of a canal, Louisvillians formed a private company to construct a canal on the Kentucky side of the river and the Indiana plan came to an abrupt halt. $^{19}$

Northern and East Coast interests viewed the canal as vital to insuring a rapid and reliable link between Midwest agricultural and manufacturing and the Port of New Orleans. The United States government also viewed unimpaired transportation and communications access via the Ohio River as essential for

18 Judy Munro-Leighton, Changes at the Falls (Louisville: Portland Museum, 1982), 45. 
national security on the frontier. Using the rationale that national interests drove the project, the Louisville and Portland Canal Company convinced the United States Congress that the United States should be a major stockholder. When complete in 1830 , a canal of three locks with a total lift of 8.5 feet marked the beginning of a period of growth for Louisville, proving false the fear that a canal would bring the demise of the city. From 1830 to 1850 , the population of Louisville more than quadrupled to $43,000 .^{20}$

By 1855 , the Falls of the Ohio again stood as an impediment to commerce as steamboat technology created vessels too large for canal passage. However, the railroad had entered Louisville and many products, especially agricultural, found an escape from the confines of the river to inland markets via the iron horse. Rail traffic grew in such abundance that in 1855 , the city of Louisville changed its official symbol from the steamboat to the locomotive. ${ }^{21}$ Nevertheless, the United States government maintained the idea of the importance of the river and the need for free navigation between important developing northern industrial centers and as a link from those cities to the Gulf of Mexico. In 1855, the federal government became the majority stockholder in the company.

Following the Civil War, the Louisville and Portland Canal Company enlarged the canal and improved the locks from a three to a two-lock system. The federal government acquired the outstanding shares of the Louisville and Portland Canal Company and turned over operations to the United States Army Corps of

${ }^{19}$ Carl E. Kramer, Visionaries, Adventurers, and Builders: Historical Highlights of the Falls of the Ohio (Jeffersonville, IN: Sunnyside Press, 1999), 99.

${ }^{20}$ Yater, Two Hundred Years, 61.

${ }^{21}$ Munro-Leighton, Changes, 21. 
Engineers. ${ }^{22}$ In 1870, the Corps of Engineers altered their mission from that of keeping the Ohio River clear of obstruction to maintaining navigation through a series of 53 locks and dams that would maintain a constant water depth of six feet from Pittsburgh to the Mississippi River. The Ohio River Division of the Army Corps of Engineers provided a complete detailed reference to the role of the corps from its initial stages of clearing the Ohio River of debris to meeting its responsibility of maintaining Ohio River navigation through their canalization strategy. Since the Louisville and Portland Canal had been upgraded in the late 1860 's, a new canal at the Falls of the Ohio would be the last of the project and completion would not come until the 1920's.

Through the Civil War, outside influences determined the future of Louisville. Louisville and the adjacent Falls of the Ohio proved vital to Northern industrialists and Midwest farmers in need of rapid transportation of goods to the expanding West and the developing South. During the Civil War, the United States Army used Louisville as its base of operations for the Army of the Ohio. From the Falls of the Ohio, communications and supplies traveled deep into southern territory for troops in the field. The Louisville and Nashville Railroad, begun in the 1850 's, provided an overland link to Nashville and other inland destinations through connections with other rail lines. Therefore, goods, troops and communications traveled from the North to Louisville and then to a variety of destinations in the South. The quality of connection through the L \& N was so good that, at the outset of the Civil War, supplies continued to flow through

22 Chuck Parrish, District Historian, U.S. Army Corps of Engineers Louisville, letter to author, 12 February 2003. 
Louisville to serve the Confederate cause. In May 1861, the United States

Treasury Department issued a directive forbidding trade of provisions and munitions to the South. The orders and legal decision of the Jefferson County Circuit Court to the L \& N largely went disregarded. Ironically, in July 1861 the Confederates cut the link between Louisville and the South and Confederate Governor of Tennessee, Isham G. Harris, ordered the seizure of L \& N rolling stock in the state. To avoid any further loss of locomotives and rail cars, the L \& $\mathrm{N}$ ceased all operations to the Confederacy. ${ }^{23}$

In 1862, Confederate General Braxton Bragg attempted to bring Kentucky into the Confederate fold by invading the state. He advanced with an army of 40,000; a number that proved insufficient to establish control of Kentucky. The general believed that he could gain recruits from slaveholding Kentuckians whom he assumed were sympathetic to the Confederate cause. He moved toward Bardstown, Kentucky, as part of his recruiting drive, perhaps to bolster his troop strength before assaulting on Louisville. At Glasgow, Kentucky, Bragg told a crowd to "cheer us with the smiles of your women and lend your willing hands to secure you in your heritage and liberty." ${ }^{24}$ However, journalist Whitelaw Reid, who traveled with Bragg's army, reported that following Bragg's invasion, Bragg said that most citizens of Kentucky were "shuffling middlemen, who take no part in this unhappy contest and who are waiting to see which side is successful. ${ }^{25}$

\footnotetext{
${ }^{23}$ Kincaid Herr, The Louisville and Nashville Railroad: 1850-1963 (Lexington, KY: University of Kentucky Press 1964), 1-34.

24 James Lee McDonough, War In Kentucky: From Shiloh to Perryville (Knoxville, TN: University of Tennessee Press, 1994), 155.

${ }^{25}$ James G. Smart, A Radical View: The "Agate" Dispatches of Whitelaw Reid 1861-1865 Vol I (Memphis: TN: Memphis State University Press, 1976), 92.
} 
While Bragg moved from town to town, foraging for supplies and continuing his recruiting drive, General Don Carlos Buell returned to Louisville with his Army of the Ohio and secured the Falls City from invasion. In October 1862, Bragg attempted a political takeover of the state when he sent a detachment to Frankfort to observe the swearing in of a Confederate governor, hoping that the symbolic ceremony would persuade Kentuckians in the allegiances. But Buell led his army of 75,000 out of Louisville toward Bardstown, with a portion ordered to Frankfort. The swearing in of the Confederate governor fell in disarray abruptly when the report of booming federal cannon ended the festivities. Bragg consolidated his troops at Perryville, Kentucky, where he encountered Buell's forces as matter of happenstance rather than strategy. Following a battle that lasted an afternoon and evening, Bragg withdrew from the state and Kentucky never again faced a serious invasion for the remainder of the war, although bushwackers and guerillas remained a problem throughout the war. Once the threat of invasion had abated, Louisville stood secure as a Union stronghold and the local economy prospered. Supplies from Louisville manufacturers flowed freely to the troops in the field via the Ohio River and the L \& N Railroad. Following the war, the $\mathrm{L} \& \mathrm{~N}$ stood as the southern most railroad left almost unscathed by the scars of battle. Most of its rolling stock remained in tact and its finances sound. Merchants and manufacturers stood poised for a postwar boom since the infrastructure of the city had been untouched by battle and federal and state government contracts brought prosperity to many in the city.

Since the eighteenth century, Louisville possessed consistent links to the 
Northeast, the Upper Ohio Valley, and the Great Lakes territories and states.

Although the city was founded when Kentucky was a part of the Virginia colony, its importance resided in its strategic military position protecting mainly the northern colonies. Following the Revolution, commercial concerns in the North spurred its development and the development of the Louisville and Portland Canal was a scheme designed to enhance Louisville's northern economic ties. Farming interests in the Midwest looked to Louisville as a destination from which agricultural products could be dispersed to various markets. City leaders viewed northern cities such as Cincinnati and Pittsburgh as economic rivals. However, the allure of Louisville to Northern interests lay in its access to southern markets, first by water and then the railroad. For a century, prior to the 1870's, the city's economic development had been linked to northern interests. By the 1870 's, city leaders began to take a more independent approach to progress by taking advantage of its geographic position as a northern industrial city standing at the gateway to the South; a South with enormous post-war needs.

\section{Business and Politics}

1880 found Louisville continuing to grow in size and stature. The population expanded in the previous decade by $23 \%$ to over $123,000 .^{26}$ Given the close association of the city to the Union during the Civil War and the fact Kentuckians rejected secession and the Confederacy, political allegiance might reasonably be 
assumed to have remained with the North, if not with the Republicans. However, disaffection with the victors ran high. During the war, Union officers commandeered supplies in return for vouchers that the federal government was slow to honor. The supply needs of the Union Army depleted the livestock, agricultural, and food supplies in the state. Federal military governance remained in place for several months following Lee's surrender at Appomattox Courthouse in April 1865. Major General John Marshall Palmer used his authority as state federal Commander to free the slaves in Louisville and thereby embittered local slave holders and much of the population against the Republicans and the Union cause. General Palmer issued numerous railroad passes to slaves before ratification of the Thirteenth Amendment to the United States Constitution, which Kentuckians resisted. Kentucky Governor Thomas Bramlette urged the Kentucky legislature to vote for the amendment on the grounds that slavery in the United States was doomed. Nevertheless, the legislature defeated passage of the Thirteenth Amendment. Historians Tapp and Klotter argue that the battle over the Thirteenth Amendment defined Kentucky's future political alignment. ${ }^{27}$ At the outset of the Civil War, a majority of Kentuckians considered themselves Union Democrats who believed that the Union, with slavery, should be preserved. Historian Eric Foner found that "Kentucky became firmly committed to the Union, but throughout the war remained under the control of a conservative Unionist coalition that steadfastly opposed all federal policies that

${ }^{26}$ United States, Tenth Census of the United States 1880: Part II The Southern and Western States (Washington, D.C.: Government Printing Office 1887), 122.

${ }_{27}$ Hambleton Tapp and James C. Klotter, Kentucky: Decades of Discord 1865-1900 (Frankfort, KY: The Kentucky Historical Society 1977), 2-3. 
threatened to undermine slavery." 28 Following the war, the Union Democrats favored restoration of social, economic and political positions of everyone who had left the state to fight for the South and a go-slow policy on race relations. The Unionist's support of a policy of general amnesty and acceptance to exConfederates aided the efforts of returning soldiers of the South to regain their former positions of status in Kentucky and Louisville's business and society. Tapp and Klotter reject the notion of inconsistency regarding the switch of Union Democrats from opposing secessionists to realignment with their former adversaries. They assert that Kentuckians' conservative nature necessitated a desire to revert to the past. Tapp and Klotter describe this shift as an interpretation by many that Kentuckians rejected all reform and industrialization in an effort to return to an agrarian past. ${ }^{29}$ Nevertheless, in contrast with the state, Louisvillians embraced industrialization and looked toward the future.

Five months following Lee's surrender, the Louisville Democrat reported that "every carpenter, brick layer, and plasterer in the city kept busy." ${ }^{30}$ Despite a few national "panics" from periods of economic recession, the postwar boom in Louisville continued in the following decades. Similarly to the building of the Louisville and Portland Canal, Louisville merchants feared a railroad bridge spanning the Ohio River would turn the city into "simply a way station." Louisville historian George Yater pointed out in Two Hundred Years of the Falls of the Ohio that Louisville Board of Trade president Venerando Politza

${ }^{28}$ Eric Foner, Reconstruction: America's Unfinished Revolution 1863-1877 (New York: Harper and Row, 1988), 37.

29 Tapp and Klotter, Decades, 4-5.

${ }^{30}$ Yater, Two Hundred Years, 103. 
Armstrong argued that the bridge would benefit the L \& N Railroad and not the city. ${ }^{31}$

However, University of Louisville historian Leonard P. Curry in Rail Routes South points out that the Louisville Board of Trade expressed concern in 1865 that Louisville lacked rail connections with the North. Railroads from the West and North such as St. Louis and Chicago terminated across the Ohio River from Louisville in New Albany, Indiana and Jeffersonville, Indiana. The bridge, first proposed in the 1850's, received opposition from Cincinnati trade interests who falsely claimed a bridge would impede navigation, even though the plan called for a bridge clearance some ten feet greater than the clearance of the railroad bridge in Cincinnati. Curry stipulated that the true opposition from Cincinnati was found in a November 18, 1868 Louisville Courier-Journal editorial that said, "one reason why Louisville has not heretofore secured her proper share of the trade in Indiana is because the Ohio River presented an obstacle to the shipment of freight and the convenience of travel.",32

For its part, the $\mathrm{L} \& \mathrm{~N}$ railroad argued that a direct rail connection to the North would not only promote through freight traffic, but also connect Louisville's manufacturers to all parts of the nation. $L \& N$ management recognized that cooperative agreements with other railroads for express freight service lowered the cost of long shippers and turned the $L \& N$ from a local road into one with a national reach. ${ }^{33}$ The $\mathrm{L} \& \mathrm{~N}$ stood to make financial gains with direct routes to

\footnotetext{
31 Yater, Two Hundred Years, 99.

32 Leonard P. Curry, Rail Routes South: Louisville’s Fight For The Southern Market, 1865-1872 (Lexington, KY: University of Kentucky Press 1969), 27.

33 Herr, L \& N Railroad, 41.
} 
the North by gaining transportation market share from the river trade. Between 1865 and 1868, Louisville's river trade with northern destinations constituted fifty-seven percent of all river traffic while southern interests comprised twentytwo percent of total river trade. ${ }^{34}$ On March 1, 1870, the longest iron bridge in the United States opened for rail traffic across the Falls of the Ohio. Not only did the bridge allow for through freight to all points in the nation and link Louisville's manufacturers with Northern and Western markets, but it also bucked the southern isolationist political trend of Kentuckians as the L \& N symbolically crossed the traditional North-South divide.

At the same time, Louisville merchants fought against the "Short Line" project, which would link Louisville, Lexington and Cincinnati by rail. Louisville's consistent economic rivalry with Cincinnati caused merchants to fear a rail link from the Queen City to the ever-expanding reach of the $\mathrm{L} \& \mathrm{~N}$ Railroad. L \& N officials lobbied hard for the project as they realized looking out simply for the interests of Louisville damaged its own traffic and profit potential. City merchants viewed the line as ceding Louisville's advantage over Cincinnati in competition for southern markets, as the geographic restrictions of river trade with the South became apparent. In the year 1869-70, the L \& N shipped nearly four times as much freight to the South as it did toward the North. ${ }^{35} \mathrm{~A}$ compromise between the parties that the gauge of the short line would not match that of the $\mathrm{L} \& \mathrm{~N}$ in Louisville making freight transfers necessary led to the

34 Curry, Rail Routes South, 30.
35 Curry, Rail Routes South, 31. 
completion of the connection in $1868 .^{36}$ The failure to create a consistent gauge may have satisfied Louisville merchants, but Cincinnatians realized that the connection did not result in a clear route to the South. The necessity of transfer made certain the control of Cincinnati freight by Louisvillians. Cincinnati business and political leaders proposed a separate, direct line from the Queen City to Chattanooga that by-passed Louisville altogether. To overcome the perception that Cincinnati was a "radical Republican hotbed," Cincinnati lobbyists aligned themselves with the legislators of Kentucky by framing the issue as rural Democrats wresting control of transportation from Louisville's urban Democrats. After many years, the lobbyists convinced a majority of the Kentucky legislature of the benefits that a direct line from Cincinnati to Chattanooga held for the rural bluegrass of Kentucky. The process resulted in the completion of the Cincinnati Southern Railway in $1880 .{ }^{37}$

By 1880 , Louisville manufacturers continued to seek markets across the nation. But, the national rail network had matured to the point that east-west traffic necessitated Louisville manufacturers focus their attention on the South for trade. The L \& N network obliged both desires by following a strategy of expansion through connections with northern lines and acquisition of southern railroad interests. Though family ventures and small partnerships were numerous in Louisville business, powerful families of wealth emerged and created what

\footnotetext{
36 Yater, Two Hundred Years, 101.

${ }^{37}$ Curry, Rail Routes, 52-139. The political and legislative process leading up to the construction of the Cincinnati and Southern Railroad lasted from 1868 to 1872 and was quite involved complicated. Curry devoted a majority of his work to the subject in great detail.
} 
Tapp and Klotter refer to as a "class conscious society" in the Falls City. ${ }^{38}$

Manufacturers like George Ainslie, who produced steamboats, became

millionaires. B. F. Avery \& Sons became the leading plow manufacturer in the world, turning out 600 plows a day and employed 250 people. By 1868 , company founder Benjamin Avery emerged as one of Louisville's highest individual taxpayers with payments in excess of $\$ 60,000 .^{39}$ Dennis Long \& Company grew to be the largest cast-iron pipe manufacturer in the world and the city's tobacco market was second to none. ${ }^{40}$ Tobacco processing expanded with the market as well with the number of tobacco enterprises increasing from 50 with capital of $\$ 473,000$ and 754 employees in 1870 to 61 tobacco processors with $\$ 708,000$ in capital and 1900 employees in 1880. Employment rolls of tobacco concerns in 1880 included over 500 women and 300 children. Growth in distilleries made Louisville a leader in worldwide distribution of spirits and added to the city's economic expansion. Distilleries grew from 24 with 221 employees in 1870 to 35 and over 600 employees a decade later. During the same time span, the value of distilled products more than doubled from just under a million dollars to more than $\$ 2.3$ million. $^{41}$ Older, more established families also found new prosperity with the industrial prominence of Louisville. James B. Speed's Louisville Cement Company reached a national market that included at least five carloads of product sent to Chicago daily. ${ }^{42}$

\footnotetext{
38 Tapp and Klotter, Decades, 308 .

39 Tapp and Klotter, Decades, 308.

40 Yater, Two Hundred Years, 122.

${ }^{41}$ United States, Ninth Census of the United States 1870: Statistics of Population, Vol. I

(Washington, D.C.: Government Printing Office 1872) 667; United States, Tenth Census, 130.

42 Yater, Two Hundred Years, 101.
} 
Though ever fearful of railroad expansion, millionaires also emerged from the ranks of Louisville merchants. Textbook publisher J.P. Morton, newspaper publisher Walter N. Halderman, and wholesale grocer William Gay all rose to social and financial prominence by 1880 . Nathan Bloom and Joseph T. Tompkins enjoyed great financial gains in the dry goods business. ${ }^{43}$ John. H. Leathers formed a partnership with John Tapp to manufacture Kentucky Jeans. The inexpensive trousers had been the primary clothes provided for slaves in antebellum days and had, by 1880 , become popular with industrial workers across the nation. ${ }^{44}$ The manufacture of men's clothes grew in importance to Louisville's economy from 1870 to 1880 , though the number of enterprises declined, perhaps as part of consolidation. In that ten year interval, the number of men's clothing interests fell from 51 to 35 but the number of employees tripled to more than 1500 and product valuation doubled to over $\$ 1.3$ million. ${ }^{45}$

Other industries that grew to national prominence in Louisville included meatpacking, especially pork. In 1880, Twenty-three slaughterhouses employed 358 men and 8 children with products valued in excess of $\$ 4.2$ million, which exceeded that of any other individual business for the year. The slaughterhouses required large stock yards and livestock production resulted in Louisville providing much of the nation with various leather products. Throughout the decade leading to 1880 , some 18 leather establishments remained in operation with employment quadrupling from near 100 in 1870 to over 400 ten years later. The value of products also increased from just over $\$ 900,000$ to over $\$ 2.1$

43 Tapp and Klotter, Decades, 308.
44 Yater, Two Hundred Years, 123. 
million. ${ }^{46}$

Prosperity not only translated into the general economic welfare of the city and the personal fortune for business leaders, but also served as the foundation for the social and political class of Louisville. Walter N. Haldeman owned and operated the Louisville Courier newspaper through the Civil War. On November 8, 1868 he bought out two of his rivals, the Louisville Democrat and Louisville $\underline{\text { Journal }}$ and consolidated all of the newspapers into the Louisville Courier-Journal. By eliminating some of his competition, Haldeman gained a larger market share in the hopes of expanding his fortune. More significantly, he named former Confederate journalist Henry Watterson as managing editor of the CourierJournal. Under Watterson's guidance, the Courier Journal became a newspaper of national influence.

As editor of the state's largest newspaper, Watterson became influential in state politics and helped to shape the future of both Louisville and Kentucky. The Democrat Party had established itself as the party of choice in the state, but a split in the early 1870 's fractured party loyalties. The conservatives, who wished to maintain the antebellum traditions, social customs and economy became known as the Bourbons. The Bourbons controlled much of the party and legislative apparatus as well as the political conventions. Watterson led a group known as New Departure Democrats who advocated industrial progress and unity with the nation as a whole. Though an ex-Confederate, Watterson argued that the best interest of the state resided in a political alliance with between the northern and

${ }^{45}$ United States, Ninth Census, 667; Tenth Census, 130.

${ }^{46}$ United States, Ninth Census 667; Tenth Census, 130. 
southern branches of the Democrat Party as well as compromise with elements of the moderate Republicans. Such a strategy meant accepting not only the Thirteenth Amendment, but also supporting the Fourteenth and Fifteenth Amendment as well. Watterson maintained that, in accepting the results of the war, the South had to view itself as part of the nation as a whole and act accordingly. In an August 16, 1871 editorial, Watterson argued:

The South can not stand alone. She has lost her political ascendancy. Not only the war has destroyed her power in Government, but immigration has disturbed the equilibrium which she enjoyed. There is no longer any reason why the South should be sectional, and there is a very strong reason why she should not be. We can not stand alone. If we expect to hold our own, we must not cling too tenaciously to that which is exclusively provincial and which can not be made to harmonize with that which is truly national. The rule of association requires some sacrifices of all concerned, and if we are ever to secure the co-operation of the really live and active elements of the North and West, we must adapt ourselves to a somewhat larger plan than that mapped out in the fancy of an impracticable and narrow-minded provincialism. ${ }^{47}$

Watterson was a well-traveled man and had noticed the people of the North had left the war behind and worked toward a future of material wealth, social progress and poltical and social happiness. He observed the rapid economic advancement in states north of the Ohio River versus the stark contrast of relative poverty and stagnation in the South. He therefore sought increased industrial growth in the state. Louisville's natural assets set the city up as ideal to lead the state into the new age. Through editorials and lobbying, Watterson helped change the attitude of his party and succeeded in convincing lawmakers to support natural resource development, improvements in transportation, and state and local

47 “An Idiotic Gabbler," Louisville Courier-Journal, Weekly Edition, 16 August 1871. 
incentives for industrial development. ${ }^{48}$

Contrary to what his adversarial Bourbon detractors perceived, Watterson's motive resembled the Bourbon goal of re-establishing southern political and economic power in the nation. However, the Bourbon approach upheld the "Lost Cause" mentality that swept through much of the South. Historian David W. Blight argues the "Lost Cause" ideal arose from the physical destruction and following psychological trauma of a defeated South. He describes the "Lost Cause" in religious terms in which southerners grabbed on to specific traditions, rituals and arguments that mythologized the past. Robert E. Lee became the embodiment of a near god-like figure whose defeat only came about due to insurmountable odds and unfortunate circumstance. ${ }^{49}$ Instead of grasping to the traditions of the past, Watterson looked to build a new South based on post-war reality. His immediate concern rested in the roles the Radical Republicans played in Reconstruction. Watterson biographer, Joseph Frazier Wall, suggested that Watterson's approach was simple and seemed obvious to the politically astute editor:

Give the Radicals no excuse for intervention through mistreatment of the Negro or acts of violence against the carpetbagger. Reveal to the moderate men of the North, who Watterson was convinced, still comprised the major portion of the public that the South could be trusted with self-government. With the resulting removal of military rule, the South would go Democratic and with the Democrats in the North would sweep the Radicals back into the gutter from which they had climbed.

48 Tapp and Klotter, Decades, 32-33.

49 David W. Blight, Race and Reunion: The Civil War in American Memory (Cambridge, MA: Belknap Press 2000), 258. 
It was as simple as that to restore the Union to prosperity and peace. ${ }^{50}$

In essence, Watterson felt the best way to return the South to prosperity was through reconciliation. He began in Kentucky where his fight to provide Blacks with schools and opportunities for employment as well as a general acceptance of the Fourteenth and Fifteenth Amendments met stiff opposition. But Watterson continued with his editorials that argued for the advantages of such a position. In 1871, a Democrat convention in Dayton, Ohio resulted in a series of resolutions that called on Democrats to "accept 'the natural and legitimate results of the war' including the recent constitutional amendments, and to turn to the living issues of the present." Wall wrote that the feeling at the convention was that the resolutions would provide a "new departure" for the Democratic party, which should appeal to liberal Republicans everywhere. Wall asserts the Dayton convention not only gave Watterson confidence that his positions had received official endorsement, but also provided a moniker for the movement. ${ }^{51}$ Watterson pushed for education reform for Black children in Louisville, where in antebellum days no provision existed for the education of Blacks. Following the Civil War, property taxes from Black citizens funded Louisville schools for Black children. Watterson recognized that the meager locally segregated revenues failed to meet the needs for the proper education of Black children. In 1884, through his political connections and powerful editorials, Louisville adopted Watterson's

\footnotetext{
${ }^{50}$ Joseph Frazier Wall, Henry Watterson: Reconstructed Rebel (New York: Oxford University Press 1956), 90-91.

51 Wall, Watterson, 92-96.
} 
proposal that the education of all children be funded equally. ${ }^{52}$

Watterson's efforts to resist the Bourbons and the "Lost Cause" of the South and the northern Radicals caught the attention and admiration of northern newspapers. In July 1870, the New York World described the Courier-Journal in an editorial as "by far the ablest Democratic paper in that state and one of the ablest in the country." The World went on to point out the influence that Watterson had on the political scene. New York World editor David G. Croly wrote to Watterson that he was "too large a man for Louisville" who was "driving a six horse team to a buggy" and suggested he belonged in New York at an independent paper. The New York Times also praised Watterson and the Courier-Journal and Parke Godwin of the New York Evening Post encouraged Watterson in a letter saying, "I hope you may go on with it, till the mean and contemptible little prejudices of locality which prevail are utterly extirpated from this nation. ... The Courier-Journal is discriminating, broad, earnest and noble." ${ }^{53}$

Though Watterson spoke in general terms concerning the economic development of the South, his editorials gave the Courier-Journal a reach far beyond the state of Kentucky. The paper itself, with stories on local development and advertisements from local manufacturing interests, reminded people across the nation that Louisville was a growing industrial city with the capability to serve the needs of the West and North as well as the South. Haldeman did his part by using the reach of the $\mathrm{L} \& \mathrm{~N}$ to implement Watterson's objectives. Through the $\mathrm{L}$ \& N, Haldeman distributed the Courier-Journal throughout the South. An

52 J. Stoddard Johnston, ed., Memorial History of Louisville From Its First Settlement to the Year 1896 Vol. I (Chicago and New York: American Biographical Publishing Company, 1896), 107. 
Arkansas paper in 1874 reported they knew "no market but Louisville." Interest from southern markets gave incentive to Louisville entrepreneurs to send sales representatives to towns and individuals in the South. John P. Morton took advantage of the southern religious fervor toward the "Lost Cause" and hired teachers and preachers to peddle books as part of his crusade as the "publisher to the Lost Cause." Loyalty to the city ran high among the salesmen who, if they could not fill orders for their company, recommended the services of other Louisville firms. The travelling salesmen saavily altered their dress to match their audience, from elegance for the well heeled to rough and dirty for the less affluent. Military titles such as Colonel or Major came into use to define their background, which almost never was assumed to be that of the Union Army. ${ }^{54}$ Military titles were not limited to individuals marketing their wares. As a matter of prestige, business leaders also maintained their ties to military service. John H. Leathers served as a sergeant major in General Thomas J. Jackson's "Stonewall" brigade of the Army of Northern Virginia. Upon his return to Louisville, Leathers became active in the Second Presbyterian Church of Louisville and was named Captain of the Louisville Legion, a part of the state militia. As "Captain" Leathers, he gained employment as an accountant with the wholesale clothing firm of Jones \& Tapp. Company president, Presley Hardin Tapp had begun a small clothing enterprise making Kentucky jeans in 1866 . He realized the marketplace was in need of neat, inexpensive, durable clothes and that the cloth used for Kentucky jeans could help meet the need. He pioneered the

53 Wall, Watterson, 95.

${ }^{54}$ Tapp and Klotter, Decades, 306-07. 
use of his product on a broad scale and demand for his suits and clothes expanded his small enterprise such that he eventually employed over 500 Louisvillians. Impressed with the work of his young bookkeeper, Tapp offered Leathers a full partnership and the firm's moniker changed to Tapp, Leathers \& Company. Leathers' stature rose in 1880 with his elevation to the rank of Major in the Louisville Legion by Adjutant General J.M. Wright. Captain John Leathers then became Major John Leathers and, although he never served the Confederacy as an officer, his new title created that illusion and added to his social standing and prestige. $^{55}$

In 1879, the Louisville Board of Trade re-organized to help facilitate the growth of the local economy. The board elected F.D Carley as President. Carley made his fortune developing Kentucky coal fields and also in the expanding oil refining business, where he was involved in questionable business practices associated with John D. Rockefeller's Standard Oil Trust. ${ }^{56}$ James Wright served as Adjutant General of the Louisville Legion, but instead was known as either Major or Colonel for his service in the Union Army. Colonel Wright was named as superintendent of the board and the Memorial credited him with keeping expert records and making detailed annual reports. Wright's diligence to detail and record keeping proved vital in his role as chief organizer for the inaugural Southern Exposition that opened in Louisville in 1883. Wright also served on the founding board of the Louisville Library Association. ${ }^{57}$

55 Johston, Memorial, 460-62.

${ }^{56}$ Ron Chernow, Titan: The Life of John D. Rockefeller, Jr. (New York: Random House 1998), 254-55.

57 Yater, Two Hundred Years, 110; Johnston, Memorial, 424,531. 
As evidenced by Wright, military titles in the 1870 's were not limited to ex-

Confederates and the Democrat party and neither was local journalism. Prior to the Civil War, Robert M. Kelly gained admittance to the Kentucky Bar and contemplated a law career. With the advent of hostilities, Kelly's attention became focused on military tactics and he was commissioned as an officer in the Union Army. Kelly served in the Tenth Union Kentucky Volunteer Infantry Regiment as a Major under General Grant at the 1863 battles of Chickamauga and Chattanooga. Following a promotion to the rank of Colonel after the battle of Chattanooga, Kelly served under General William T. Sherman during the Atlanta campaign. Colonel Kelly abandoned his law career after the war and served briefly as United States Collector of Internal Revenue before being named editor of the Republican newspaper, the Louisville Daily Commercial. Consolidation of newspapers left the Courier-Journal as Louisville's only morning daily and Republicans formed the newspaper to offset the editorials of Henry Watterson. Though the paper struggled and went through a number of organizational changes, Colonel Kelly remained as editor into the 1880 's. Under Kelly's direction, the paper developed into a leader of Republican journalism throughout the region as an ardent supporter of Republican administrations and their policies. In 1873, in an act of probable patronage, President Grant appointed Kelly to the post of United States Pension agent, which he held through $1880 .{ }^{58}$

Captain Thomas Speed, whose great-uncle James Speed served as President Abraham Lincoln and President Andrew Johnson's Attorney General, enlisted as

58 Johnston, Memorial, 431-33. 
a twenty-year-old in the Union Army and fought in numerous battles under the command of General William T. Sherman. At the war's conclusion, he attended the University of Michigan School of Law and later joined in the family's law practice in Louisville. Nevertheless, Captain Speed did not excel in the practice of law. Instead, he established himself as a historian of note regarding the Civil War. The community held him in high esteem for the manner in which he conducted his life as a strict Presbyterian and his conscientious devotion to others. In 1870, he married Lucy Madison Buckner, daughter of prominent Louisville Republican Colonel James F. Buckner. ${ }^{59}$

Colonel James F. Buckner was the son of Francis Buckner, who served in the command of "Light Horse Harry" Lee in the Revolutionary War. Buckner owned a large estate and a large number of slaves, but believed fervently in federal principals, the supremacy of the federal government, and the indissolubility of the Union. He organized a local regiment of men loyal to the Union and the men elected him Colonel. The regiment divided into the Twenty Fifth Kentucky Infantry and Third Kentucky Cavalry when it officially joined the forces of the Union Army. His son, Gabriel Lewis Buckner followed suit, joining the ranks of the Union and rising to the level of Captain. Captain Lewis Buckner studied the law at the University of Louisville after the war and eventually became Collector of Internal Revenue for the Louisville district. Though not active in party politics, Captain Buckner gained a reputation as a Republican with old southern leanings. ${ }^{60}$ Not all of the leading businessmen and politicians in Louisville had

\footnotetext{
59 Johnston, Memorial, 460-62.

60) Johnston, Memorial 450-51, 455-56.
} 
connections to military service. John G. Barret entered the University of Louisville's school of law at age nineteen in 1848. Upon graduation, he formed a partnership with Hamilton Pope and continued in a legal career until 1861. Instead of joining the army of either side in the Civil War, he turned his attention to banking. Initially serving as a cashier for the Southern Bank, he went on to found Citizen's Bank along with William B. Belknap and eventually became the bank's president. A physically slight man, Barret developed a reputation as a wise financier and therefore wielded power. He helped organize the Bourbon Stock Yards Company, which became prominent in the meat packing business and founded the American Printing House for the blind. Barret expanded his work toward the education of the blind when he served as treasurer for the Kentucky Institute for the Education of the Blind for the final twenty-six years of his life. His adherence to the strict principals of finance and devotion to using his talents to benefit the disabled perhaps rose from his devotion to the ideals of the Presbyterian Church. As a principled man, he felt his convictions fit more closely with the Republican Party and used his influence toward its support, though he never directly entered politics. Barret showed a great deal of humility as he shunned the limelight and honors that might otherwise have come to a man of his stature, though he did serve the community for a time as a commissioner of the Louisville Sinking Fund. ${ }^{61}$

Charles D. Jacob entered the world in 1838 as part of one of Louisville's most prominent and oldest families. His father, John I. Jacob, left Virginia after the turn of the nineteenth century heading west to seek his fortune. Along the way, he

${ }^{61}$ Johnston, Memorial, 566-67. 
met up with an older man in his mid-thirties, Thomas Prather. Prather was a prominent merchant in the early days of Louisville and took a liking to young Jacob. The pair came to the Falls City and established a business together that prospered and, in 1811, Jacob married the sister of Prather's wife, Anne Overton Fontaine, who bore him three children. Jacob's wife died in 1819. After becoming the first bank president of the Bank of Kentucky and president of the Louisville and Frankfort Railroad, John I. Jacob married Lucy Donald Robertson, whose grandfather was President Zachary Taylor. Together the couple had ten children including Charles D. Jacob and Thomas Prather Jacob. After a bout of diphtheria in 1857, Charles Jacob convalesced in Europe before returning to Louisville in 1859. His schooling interrupted, Charles had intended to complete his studies, but never did. Poor health limited his activities throughout the decade. Nevertheless, beginning in 1870 , his prominence rose.

In 1870 , Jacob won a seat on the city council and, in 1872 , he defeated a powerful incumbent, John G. Baxter, for mayor. At age 32, Charles D. Jacob became Louisville's youngest mayor. He successfully retained his position in the election of 1875 , but term limits of the city charter prevented a third term in 1879 , when Baxter won election to the Mayor's office. Following the death of his second wife, Jacob again sought Europe as a refuge to convalesce before returning in late 1880 . He again ran for mayor in 1881 and received 14,260 out of 15,000 votes and served until 1884. Later Jacob served a fourth term as mayor, though illness forced him to take a leave of absence and an around the world trip to recover. He later served as Ambassador to Columbia during the administration 
of President Grover Cleveland. ${ }^{62}$ While Charles D. Jacob's success can be used as a measure of his popularity, the political activities of his time tell a different story.

Democrat control of the local government persisted through for several decades following the Civil War. The Republican Party did not formally nominate a mayoral candidate until 1887 . Nevertheless, local rivalries split the Louisville Democrats and elections turned bitter. In her 1970 University of Louisville thesis, Charlene M. Cornell outlined the cronyism, charges of vote buying, police bullying, and general corruption of each local election, especially when John G. Baxter was involved. Many of the charges surround Baxter, though Jacob's campaigns also were plagued by charges of malfeasance. Cornell concluded that corruption, voter intimidation, and voter fraud in Louisville elections forced the state legislature to pass a number of election reform bills at the end of the 1880's. ${ }^{63}$

\section{Everyday Life}

In spite of the political unrest in Louisville in 1880, Louisville flourished as a community. Louisville author Melville O. Briney indicated that the most fashionable part of town was considered to be Walnut Street. Perhaps it is not surprising the area came to prominence under the influence of Thomas Prather

${ }^{62}$ John E. Kleber, ed., Encyclopedia of Louisville, (Lexington, KY: University Press of Kentucky, 2001), 429; A complete biography of Charles D. Jacob and his family can be found among numerous listings of prominent Louisvillians as determined by the cditor of the Encyclopedia of Louisville.

${ }_{63}$ Charlene M. Cornell, Louisville in Transition: 1870-1890, Master of Arts Thesis, University of Louisville, 1970, 140. 
and John I. Jacob. With their early success in their mercantile firm, Prather and Jacob, the partners purchased large pieces of real estate. Their adjacent homes on Walnut Street each took up an entire city block. Following Prather's death in 1852, the family home was destroyed by fire and the land was sold in blocks for development. The trend had been set, however, and Louisville's finest families established residences in the region. ${ }^{64}$

Thomas Prather Jacob established his family residence east of his paternal home where he raised his three sons: John, Thomas and Donald. When Charles D. Jacob went to Europe in 1879 following the death of his wife, he took along as a traveling companion his nephew, John. At the age of 18 , John was the oldest of the three brothers and the relationship with his siblings apparently was quite close. His thirteen-year-old brother Thomas Prather Jacob, Jr. corresponded with him regularly, detailing the daily activities of the day. A curious note regarding the correspondence is that Thomas addressed the letters to John Jeremiah Jacob. However, many narratives and historical documents list the oldest of Thomas Prather Jacob's children as John I. Jacob. Records at the Cave Hill Cemetery also refer to John I. Jacob, Jr. but the head stone of the eldest son of Thomas Prather Jacob, born in 1861, is inscribed as John J. Jacob, died December 20, 1943. The only conclusion that can be reasonably reached is that cursive handwriting of the day made for confusion between an "I" and a " $\mathrm{J}$ " and that the assumption was made that Thomas Prather Jacob had named his son for his father. The context of the letters from Thomas P. Jacob, Jr. indicates they are intended for his brother.

${ }^{64}$ Melville O. Briney, Fond Recollections: Sketches of Old Louisville (Louisville: Louisville Times, 1955), 7-10. 
In a letter dated November 17, 1879 Thomas P. Jacob, Jr. wrote of a walk he and his father took on Lexington Road after taking a car. Electrification of Louisville's transportation was not yet a reality and so it is likely a horse drawn trolley was the source of the reference. On his walk, Thomas noted the sounds of squealing pigs from the nearby stockyards and added that a relative, Will Pope, had secured a job at a pork house for $\$ 60$ a month. The references to Louisville's economy continued throughout all of his correspondence and reveal a high level of sophistication for such a youngster.

According to young Jacob, the L \& N stock rose to 90 and he proclaimed to his brother, "there is great excitement in New York over stocks." In more economic news, Thomas reported that a shipment of six million bushels of coal were due to arrive from Pittsburgh with over a third as Louisville for a destination. Thomas seems well aware of the fuel required for Louisville's expanding manufacturing economy as he went on to specifically quote the price of Kentucky coal arriving by train had fallen from four dollars a bushel to two dollars and seventy five cents and Pittsburgh coal from six dollars to four. He exclaimed there was "quite a panic" but did not explain further. Though the railroads had usurped the dominance of the Ohio River in the vitality of Louisville, the river still maintained an over riding presence. Thomas reported that the river had risen, but when it was low, "papa went out on the rocks," perhaps a reference to the rocks that created the Falls of the Ohio. ${ }^{65}$ The frequency of Thomas' passing references to the Ohio

65 Thomas Prather Jacob, Jr., Letter, 17 November 1879, John Jeremiah Jacob 1861 - : Letters 10 Him From Brother Thomas Prather Jacob, Jr. During Trip to Europe 1879-1880, Filson Historical Society, Louisville, KY. John Jeremiah Jacob traveled to Europe with his uncle, former Louisville Mayor Charles D. Jacob, from late 1879 to mid 1880. Thomas Prather Jacob, Jr. corresponded 
River indicates its influence on the affairs of Louisvillians in 1880. Its rise and fall dictated when vessels could safely pass the treacherous rapids of the Falls. Low water forced traffic to make a stop in Louisville or pass through the canal. High water allowed for safe passage over the Falls but when the river rose too much, Louisville felt its wrath.

When discussing Louisville's climate, the Memorial History of Louisville refers to the city's vulnerability to wide seasonal weather variations but defers mention of a heat wave in 1881 that resulted in a number of Louisville deaths. Instead, the Memorial, similar to other published documentation, first refers to the river and the winter season. Of the ten flooding events listed, nine occurred between November and March with the majority in February. The frequency of floods during the winter season is attributable to geography. As noted in the Memorial, when a winter storm center passes north of Louisville, warm air from the south permeates the region. When a storm center passes south, cold air from Canada spills throughout the Ohio Valley. The result can be heavy snowfall followed by extreme cold. On numerous occasions, Louisville's temperature dropped below zero including the then record cold of 19.5 degrees below zero Fahrenheit on January 5, 1884. The Ohio River, as demonstrated by the need of a canal at the Falls, was relatively shallow and bitter cold often resulted in the river's closure due to ice. On December 28, 1880, a frozen river resulted in the stoppage of all traffic at Louisville. Following periods of snow, ice and cold, warm air often returns to the Ohio Valley and a quick moving storm passing to 
the north may bring rain. The combination of melting ice and snow, compounded by heavy rain can spell trouble for Louisville.

February 1882,1883 and 1884 brought devastation to the city at the hands of a swollen Ohio River. An unattributed report in 1882 claimed "a great flood came in February, working more mischief on the river front than any other that ever visited Louisville." Portland apparently received the brunt of the damage. However, February 16, 1883 took the river to a level of "44.5 feet above low water mark" the highest level recorded at that time. The record fell the following year on February 17, 1884 when the Ohio River crested at 46.7 feet. A large portion of the business district suffered flood damage and the river was not recorded higher for over 50 years.

Equally as prominent in the annals of Louisville weather lore are the tales of tornadoes. Tornadoes brought destruction to the city on at least five occasions between 1854 and 1890 . The 1854 storm damaged the business district between eighth and thirteenth streets from the river for some 10 blocks, including the homes on Walnut Street. The 1860 twister came across the river from New Albany and destroyed numerous factories and homes in a path that crossed through the center of the city. Twenty-three coal barges were sunk in the river. Another storm in 1879 brought destruction in the vicinity of Cave Hill Cemetery and in 1883 another tornado greatly affected the city. The 1890 tornado outpaced all others in terms of loss of life and destruction as it ripped through the center of the city, resulting in the destruction of hundreds of homes and businesses and 
several schools and churches. Property damage exceeded $\$ 2.1$ million and nearly 100 lost their lives. ${ }^{60}$

Another aspect related to Louisville's climate and geography that greatly affected the citizens of Louisville was the pooling of water. In 1852, local historian Ben Casseday wrote:

The whole of the present site of the city at that early day was intersected with ponds of stagnant water, and as a necessary consequence miasmata were bred which produced a great deal of sickness, more especially with strangers. So great, indeed, was the influence thus induced that acclimation was then considered necessary here as it now is in New Orleans or on the coast of Africa. Many of the present citizens of Louisville will be surprised to know that this very city, now so celebrated for its healthiness as to make its salubrity an inducement to immigration from all parts of the country, was once known as "The Graveyard of the Ohio." ${ }^{67}$

Numerous improvements in sewage and drainage moved Louisville beyond the description of Casseday, including the 1854 rerouting of Beargrass Creek from its natural outlet to the Ohio River at third street to a point several miles upriver. ${ }^{68}$ Casseday mentioned the "healthiness" of the city in 1852 and in 1884 , Louisville was noted by historical author R.C. Riebel as ranking as "the healthiest city of its size in the United States." However, neither Riebel nor Casseday offer any substantiation for either of their claims of an excessively healthy city. In both cases, the hyperbole may be attributed to the improvement of the health situation in relation to the situation described by Casseday. In addition to the drainage improvements of the 1850 's, in 1879 , Louisville city engineers constructed a new enlarged reservoir and pumping system to provide the citizens with surface water.

${ }^{60}$ R.C. Riebel, Louisville Panorama: A Visual History of Louisville $2^{\text {nd }}$ ed. (Louisville, KY: Liberty National Bank \& Trust Company, 1956), 108,112; Johnston, Memorial, 21-30.

${ }^{67}$ Johnston, Memorial, 23. 
Until that time, residents relied largely on wells, which were prone to promote numerous "filth" diseases, including typhoid. The only remedy was frequent inspection for noxious odors from a particular well. The practice of smelling for contaminated well water proved less than satisfactory nor effective and the new reservoir system certainly improved conditions. ${ }^{69}$ However, other maladies of the day also plagued the region. L \& N Railroad historian Kincaid Herr mentions two yellow fever epidemics in 1878 and 1897 and even Riebel makes mention of the 1878 outbreak. Thomas Jacob, Jr. adds to the evidence that perhaps health concerns were not alleviated in Louisville by 1880 .

Thomas mentioned to his brother John that on November 17, 1879 he had stayed home from school "again with headache." Though this reference can be seen as that of a minor ailment, the verbiage suggests that headaches were not an infrequent hindrance to young Jacob. An interesting note to the text is that his mother treated him with quinine. More importantly, he casually uses the phrase "by the way" to mention the deaths of several relatives from "consumption" which again suggests a frequency to such medical circumstance. In a following letter with numerous dates, an entry on February 17, 1880 the subject of death was mentioned with the passing of "Aunt Matilda and the baby a week afterward." Disease returned in the form of a scarlet fever epidemic: "Jessie broke out with scarlet fever. Tyler Richards has it now and is very ill. Jessie has had a very mild case." An entry three days later mentioned that "Papa has had a headache for two days." Thomas proclaimed the headache had passed and thought his father was

\footnotetext{
${ }^{68}$ Yater, Two Hundred Years, 61.

69) Johnston, Memorial, 108-09.
} 
better than he was "last winter" indicating it was not an isolated incident. He noted the improvement of Tyler Richards after treatment: "Tyler Richards was leeched and is better." However, the epidemic continued to affect others as he alluded to "Mauria, George and Tom Nash have taken the fever, but have light cases." In a letter from April 12, 1880 in an apparent side note, Thomas told his brother simply that "Cliff" is in need of medical aid. ${ }^{70}$ All of Thomas' correspondence reported either death or some ailment as the result of a disease or condition. Perhaps more striking is the manner in which he addressed each case. The death of a relative or friend did not appear at the outset of any of the letters, but instead was buried in the text and mentioned in a casual manner; death and disease simply formed a part of everyday life in Louisville of 1880 .

Throughout the series of letters, Thomas made short references to daily life in Louisville. On February 17, 1880 Thomas complained about his little brother, Donald, sleeping in his bed, which may have brought back memories to John. The situation was not long lived as the first sentence of his correspondence of April 12, 1880 announced that Donald no longer was sleeping in his bed as he did not like having to sleep on his own side. The little brother also balked at having to leave the room each day and dress in the nursery. Thomas complained further of other aspects of daily life. He received a sore backside after riding for six miles on a carriage horse that was only capable of trotting. As a pastime, Thomas played a card game called whist four times a week, but claims the "Todds, Popes, Ellisons and Cochrans play six-handed every night." In a letter dated June 16,

${ }^{70}$ Jacob, Jr., Letters, 17 November 1879, 17 February 1880, 12 April 1880. 
1880 Thomas made more notations regarding construction in the city and those responsible. In a single sentence in his previous letter, Thomas mentioned F.D. Carley's construction of "six or seven homes." The homes must have impressed the young man as he again mentioned in detail the size and location of each structure as well as others going up around the Walnut Street area. Other local businessmen of prominence were listed as having built new stores around the city for themselves or family members. ${ }^{71}$

The passages reveal the Jacob's social status in Louisville as Thomas never mentioned anyone who was not of some prominence nor not involved in some project of magnitude. In Thomas' world, no one farmed or worked as a laborer. Everyone mentioned either ran a company, was involved in politics, or was having buildings constructed. It might be ascertained that the writings are the musings of a wide-eyed boy admiring the success of others. But a passage in his letter of June 16, 1880 mentioned his ride by hired carriage out River Road to the wedding of a family friend to "Senator Zebulon B. Vance of North Carolina." Aside from his keen observations regarding business activity, Thomas reported on the daily activities of John G. Baxter. The tone of his reports indicates the contempt he held for the family political rival. The accounts no doubt were for his Uncle as much as his brother and may have been written in a vindictive manner simply to appease Uncle Charlie. However, it is more likely he had adopted his family's feelings toward Baxter as his own. The majority of the text of all of his correspondence was devoted to politics and quite often-national

\footnotetext{
${ }^{71}$ Jacob, Jr., Letters 17 February 1880, 12 April 1880, 16 June 1880.
} 
politics. His ability to make a detailed analysis of all aspects politics, especially national, is quite remarkable for a thirteen-year-old boy. However, his June 16, 1880 letter brings a sense that the boy is quite intellectually advanced when he lamented the fact he only received the second highest city honors for the academic school year. He then recanted and thought it was "good" since the boy who bested him was seventeen years old. ${ }^{72}$

The daily routine of Louisvillians in the nineteenth century resembled that of other American cities though societal characteristics mirrored the city's geographic location. When one considers that Louisville rests three hundred miles south of Chicago and winters feature eighteen inches of snow with temperatures that can reach below zero Farenheit, the claim that it is a southern city rings hollow. Further, the development of the Louisville and Portland Canal to circumvent the Falls of the Ohio largely came about to benefit northern concerns. With the advent of the railroad, Louisville competed with northern transportation concerns as well as northern cities as it developed an industrial and merchant based economy. Travelers and historians referred to the city as part of the North or the West. However, Kentucky inherited the institution of slavery and, although the state's agriculture did not rely on slave labor, the slave culture influenced state and Louisville politics as well as societal attitudes. Nevertheless, Louisville's history suggests that the city grew up as a northern city and remained so through the Civil War, when the city served as a base of operations for the Union Army of the Ohio. Louisvillians had several opportunities to turn against

\footnotetext{
72 Jacob, Jr., Letter 16 June 1880.
} 
the Union, but instead defended itself against all Confederate threats. Following the Civil War, circumstance provided an opportunity for the city to define itself as it pleased and Louisvillians did so with economic expediency in mind and not historical perspective. 


\section{CHAPTER TWO}

\section{The National Exposition}

During the Civil War, much of the nation's industrial capacity and ingenuity remained focused on the war effort. Following Lee's surrender at Appomatox Courthouse on April 9, 1865, business leaders across America looked toward the future. In the South, rebuilding their infrastructure and an economy devoid of slave labor stood as the main objective. The burden, or opportunity, to rebuild the South fell on northern industry, which stood relatively untouched by the ravages of war. During the Civil War, northern interests had the capability of pursuing projects beyond the war effort, such as the transcontinental railroad and transatlantic cable, which stood as testament to the vast industrial capacity of the North. Local Louisville business leaders sought to reinforce Louisville's position as a northern industrial city untouched by war and just as capable as other industrial northern cities. Louisville had served as a supply center for the Army of the Ohio during the war and, with the $\mathrm{L} \& \mathrm{~N}$ rail lines the only remaining lines to the southern states, Louisville was ideally suited as a commercial outlet to the South.

Louisville, however, had to overcome perceptions promulgated by its association with the state of Kentucky as a whole. The per capita wealth of 
Kentucians fell well short of the national average and the statewide industrial output also lagged behind other northern states.' Historian Leonard P. Curry argued that, in spite of the many successful manufacturing concerns in the city, Louisville lagged far behind other cities in total manufacturing production. Curry pointed out further that the Journal suggested that "city funds should be used to aid in establishing new manufacturing concerns and to assist old ones to expand. ${ }^{2}$

In an effort to show the entire nation that Louisville was as advanced and capable as other northern cities to take its place on the list of industrial cities, business leaders in 1872 planned and invested in The Grand National Industrial Exposition of Louisville. George F. Downs' ledger shows that over 200 local investors purchased shares in the project at twenty-five dollars per share. Though no individual or company owned anywhere close to a majority, some of the larger investors included: John P. Morton, B.F. Avery \& Sons, James Trabue, A.V. Dupont, W.B. Belknap and Jones, Tapp Company. Investors put up ten percent of their investment initially and were required to make subsequent ten percent payments at the first of every month until the transaction was complete. ${ }^{3}$ The exposition company built a two story, seventy-five thousand square foot exposition hall on the corner of Fourth and Chestnut streets. Touted as "the largest and most complete of its kind in the United States" and "one of the most

1 Hambleton Tapp and James C. Klotter, Kentucky: Decades of Discord 1865-1900 (Frankfort, KY: The Kentucky Historical Society, 1977), 309-10.

2 Leonard P. Curry, Rail Routes South: Louisville's Fight For The Southern Market, 1865-1872 (Lexington, KY: University of Kentucky Press 1969), 35.

${ }^{3}$ G.F. Downs, Memorandum Book of G.F. Downs, Harding Collection, Filson Historical Society: Louisville, KY. Hereafter cited as Downs, Personal Notebook. 
triumphant illustrations of the character of modern enterprise," builders completed the rectangular structure in forty-five days. It featured solid walls seventeen to twenty inches thick and featured a dome structure in the middle with campanile towers at either end. An expansive basement brought the available floor space to one hundred twenty-four thousand feet. ${ }^{4}$

The exposition opened on September 3,1872 to a crowd of twenty thousand. The organizers hoped the exposition would showcase the products and capabilities of local and state industrial and science concerns as well as the arts. The vast majority of displays, numbering well over 500, originated from Louisville business. ${ }^{5}$ The Rules and Regulations of the First Grand National Industrial Exposition, published by exposition management, admitted that the original intent of furnishing the exhibition with products from the "home industry" had to be amended due to an excess of capital on hand and demand from distant exhibitors. Organizers arranged for special rail fares for all railroads that served Louisville as well as connecting rail lines. The stated purpose was to "bring together producers to meet consumers in this most accessible and central location. Louisville is the gateway of the South-the only point of exchange between the two great systems of railroads." Noting the alteration of labor conditions in the South, organizers also outlined the exhibits as those of "Machinery, Inventions, Manufactures, Works of Art, and Products of Industry." The organizers did not specifically address exhibition space for agricultural

4 "The Exposition," Courier-Journal, 3 September 1872: 2.

5 "A Great Event," Courier-Journal, 4 September 1872; "The Exposition," Courier-Journal, 5 September 1872. 
concerns. ${ }^{6}$ Aside from attracting national recognition to the resources of the city, organizers hoped for an immediate economic boost to the city. The Courier-

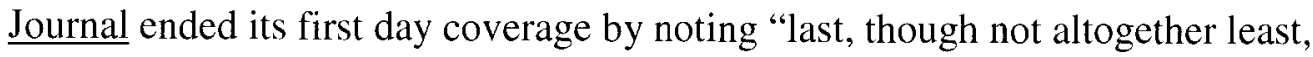
we must be pardoned for referring to several millions of dollars which our several hundred thousand visitors will leave behind them as an earnest of further favors in the future." 7

The general promotional attitude of Henry Watterson's Courier-Journal during most of the exposition reflected the editor's New Departure philosophy and advertisements in often represented northern concerns. One promoted the exhibit of "Mr. J.M. in office in Cincinnati" to aid "merchants and manufacturers who desire to avail Martson-The great artist and celebrated interior decorator who has gained such celebrity Kentucky and New England." ${ }^{8}$ Another ad announced the establishment of a Courier-Journal office in Cincinnati, proclaiming the wide circulation of the paper "throughout the South and Southwest."." The CourierJournal's announcement that it had entered the Queen City offset the call on Louisvillians to visit the city's chief rival as advertisements appeared promoting the Cincinnati Industrial Exposition, which ran concurrently with the Louisville Exposition. Promoters offered reduced fares on the L \& N from Louisville to Cincinnati for visitors who wished to see the "largest exhibition held in America" and its "one acre of machinery in motion." 10

\footnotetext{
${ }^{6}$ Rules and Regulations of the First Grand National Exposition of Arts, Inventions, Manufactures and Products, (Terrel, Dietz \& Co., Printers, 1872), 11.

7 "The Exposition," Courier-Journal 3 September 1872: 2.

${ }^{8}$ Courier-Journal 7 September 1872; 1.

9 Courier-Journal 4 October 1872; 4. Advertisements appear in numerous editions.

${ }^{10}$ Courier-Journal 5 September $1872 ; 4$. Advertisements appear in numerous editions.
} 
The coverage of the Exposition did not prevent Henry Watterson from carrying out his duties as editor of the Courier-Journal. Although his New Departure ideals called for reconciliation with the North, it did not mean he surrendered his loyalties to the Democrat party. With the approach of the 1872 presidential election between Democrat Horace Greely and Republican incumbent President Ulysses S. Grant, Watterson continued his editorials pointed at the Radicals with almost daily assaults on Grant. Watterson wrote of the controversy between those who supported President Andrew Johnson's Reconstruction policies and those of President Grant. Watterson's view criticized the actions of Grant. The editor accused Grant of wishing to enrich himself and gain power over the people like the Roman Emperor Nero and that the Radicals favored the creation of an empire or monarchy. Referred to as the Radicals" "Caesar," Grant fell under the description of "stolid, stupid and pleasure-seeking." 11 Watterson illustrated Grant's apparent inconsistency regarding his party affiliation, anti-slavery views, and sincerity to his Reconstruction policies with a quote attributed to the President, though no date was provided as to its supposed utterance.

I am a Democrat and when I am convinced that the war is waged to prosecute the designs of the Abolitionists, I pledge my honor as a Soldier that I will carry my sword to the other side, and cast my lot with That people. ${ }^{12}$

The attacks on Grant turned humorous when the Courier-Journal editor for several days offered examples of Grant's speeches. An undated speech in Philadelphia was described as "brilliant."

You have heard much better speeches to-night than I could make

11 "The Re-electionists," Courier-Journal, 28 September 1872: 2.

12 "A Leaf From Grant's Record," Courier-Journal, 1 October 1872: 2. 
if I were so inclined. I am very glad to see you and am pleased to hear that you have been to hear such fine speeches and how you have been engaged to-night. ${ }^{13}$

A speech, given at an un-named time, in Great Falls, New York was called "one of his best" and "a truly great speech." The paper opined that "we would rather be the author of it than to be the hero of a thousand Waterloos."

I thank you for this reception. I did not suppose there were so many People in your village. If people make a city, this is a city. Again, I thank you. ${ }^{14}$

Clearly, Watterson used sarcasm as a tool when he published some of Grant's shortest and most inconsequential public comments, most of which do not qualify as speeches. His goal was to paint Grant as incompetent and unintelligent in contrast to Democrat presidential candidate Horace Greely. Watterson claimed the effort reflected a desire to give a "fair hearing to both sides" by reproducing some of "Grant's ablest speeches, giving them in full, as a fair off-set for Greely's speeches that have recently occupied some of our space." ${ }^{\prime 5}$ All of Greely's speeches printed by Watterson contained more than mere pleasantries or simple crowd acknowledgement. Hence, the selective printing of Grant's "speeches" hardly qualified as a "fair hearing." In spite of Watterson's clever efforts to aid in his defeat, Grant overwhelmed Greely in the 1872 presidential election.

The exposition closed for the year on October 5, 1872 and, on that day, Watterson altered his focus from northern Radicals to advocacy of industrial development of the South. Prior to the official closing, five hundred delegates from the South visited the city to celebrate the L \& N's latest expansion, which

13 "Grant's Oratory and Greely's Wisdom," Courier-Journal, 28 September 1872: 2.

${ }^{14}$ Courier-Journal, 1 October 1872. 
was the acquisition of a line to Montgomery, Alabama. ${ }^{16}$ The Courier-Journal hailed the visit as an "epoch in the commercial history of Louisville." verbiage indicates Courier-Journal editor Henry Watterson's delight of Louisville expanding its commerce to the South and the L \& N's success at securing the southern trade from northern competitors. The $\mathrm{L} \& \mathrm{~N}$ had expanded and acquired so much track in the southern states that the railroad considered changing its name to "The Louisville and Nashville and Great Southern Railroad." The company prepared letterheads with the new moniker, but L \& N officials eventually decided against the name change. ${ }^{18}$ Nevertheless, with the L \& N setting its sights southward, the city leaders recognized the opportunities available in the South. Exposition organizers set aside October 9 th and $10^{\text {th }} 1872$ as days to specifically entertain the southern delegation, who received lunch in the exposition hall on the ninth and a banquet at the Galt House on the tenth. No citizen of Louisville, including the mayor, was admitted to either event without a ticket, priced at eight dollars for lunch and ten dollars for the banquet, though a banquet ticket allowed for entrance to the lunch. The exposition's Committee of Arrangements appointed a reception committee of forty-five prominent business leaders including: B.F. Avery, John H. Leathers, John M Harlan and James Speed. Ironically, Gen. Braxton Bragg, the man who had led the 1862 invasion of Kentucky, led the delegation from Mobile, Alabama. The southern delegates heard an oratory by Louisville Mayor John Baxter in which he declared Louisville

15 “Grant's Speeches," Courier-Journal, 30 September 1872: 2.

16 "Our New Southern Line," Courier-Journal, 27 September 1872: 1.

${ }^{17}$ Courier-Journal, 19 October 1872 
as part of the South when he said, "the great need of Louisville and of the whole South has been to have more railroads." 19

The annual Grand National Industrial Exposition of Louisville continued annually until 1882, when business leaders determined a more pointed effort, beyond special events and banquets for southerners, was needed to link the Louisville business community with opportunities in the South. October 21, 1882 marked the final day of the exposition and the Courier-Journal did not report on the exhibits or attractions. Instead, it ran two stories regarding plans for a new exposition for the following year. One story related to the minutes of Committee of Organization, which included 50 members of the Louisville business and political community. The minutes reflect the continued split between the Bourbon and New Departure Democrats. Several members alluded to the economic power of cotton in the South and desired the focus of the new exposition to reflect southern agriculture. J. M. Robinson complained the just completed exposition's scope was too broad and a new exposition should be made "strictly a southern one." ${ }^{20}$ But, Louisville Mayor Charles D. Jacob and several others protested limiting the promotion of a new exposition in such regional terms. In the overall review of the committee meeting, the Courier-Journal presented the objective of a new exposition, which illustrates a compromise between the two positions:

\footnotetext{
${ }^{18}$ Kincaid Herr, The Louisville and Nashville Railroad: 1850-1963 (Lexington, KY: University of Kentucky Press, 1964), 51-52.

19 "Our Southern Guests," Courier-Journal, 9 October 1872; "Our Welcome," Courier-Journal 10 October 1872.

20 "Organizing Success," Courier-Journal 21 October 1882: 4.
} 
The object of our citizens is to have at Louisville a display of agricultural, mineral and mechanical production, which will attract national attention, and secure the hearty co-operation of men everywhere who are interested in whatever pertains to the development and upbuilding of the Southern States. In this, there is no sectionalism, but in order to deepen public approval, such an exhibition must be to some extent localized. We do not seek to have an international exhibit, nor a second Centennial, nor do wish to repeat Atlanta. We will have an exhibition different in many respects from any which preceded it, but in a peculiar sense illustrating the progress and the future possibilities of the Southern States, using Southern in the broadest sense. Such an exhibition will arouse local enthusiasm, secure the support of the South, and the attendance of Northern, Eastern and Western exhibitors, visitors and investigators. ${ }^{21}$

Clearly, the influence of the "Lost Cause" ideal had taken root in Louisville as the Courier-Journal reflected the notion that Kentucky and Louisville belonged to the South. However, Watterson, with his Departure philosophy, and the business community of Louisville did not fight against the tide, but instead embraced it as part of their vision. With Reconstruction ended and the South in Democrat Party control, Louisville was free to exploit its established position as an industrial city and its geographic location to define itself in a manner that best suited its needs. By shedding its historic ties with the North and declaring itself as southern, Louisville could meet the desires of the Bourbons. At the same time the city's manufacturing base could continue to receive support from northern industrialists eager to enter the southern markets by making Louisville the conduit for such business transactions with local manufacturing in a position to benefit.

The only review of the exposition came the day after its closing in the form of a review from the arts editor. It stated that "Louisville is just emerged from an

21 "The National Exposition," Courier-Journal, 21 October 1882: 6; "Organizing Success," Courier-Journal, 21 October 1882: 4. 
anomalous state where she was neither provincial nor metropolitan." ${ }^{22}$ While the author was but one person, not professionally part of the business or political community, his view has value in that it indicated that ordinary citizens were aware of the transformation of Louisville. The writer went on to say that Louisville "in many respects has been transformed-has been baptized with a spirit of business, energy and commercial enterprise." He concluded, however, that the transformation was not complete because "the original sin of her art atmosphere remains behind." ${ }^{23}$ Obviously, the reviewer was not enthused by the effects of the exposition on the art community of Louisville. However, the fact that he described the city in modern industrial terms and did not refer to the traditional southern staples of agriculture may reflect Louisvillians view that their city was indeed one of industry.

Two days later, contrary to the view of the art review editor, the Courier-

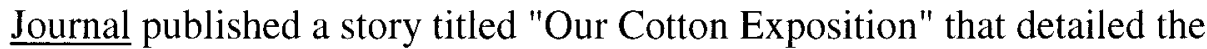
importance of cotton to the southern economy and revered Eli Whitney and his cotton gin. It went on to explain the virtue of cottonseed and its use as cattle feed, for oil, and for fertilizer. The article expanded on its agricultural theme:

But while cotton is the central thought of the South, while it is the chief cornerstone of its wealth, there are other sources of prosperity for the agriculturalist which have scarcely been touched. The fruits of Florida, the sugar of Louisiana, stock through all the States where grass will grow, and sheep everywhere demand the attention of the industrious and the provident. Southern farmers should know more of the methods used by the grain dealers; they should understand how to rotate crops, handle stock and improve the soil, and, in the neighborhood of cities,

${ }^{22}$ Courier-Journal, 22 October $1872 ; 5$.

23 Courier-Journal, 22 October 1872; 5. 
raise vegetables and early fruits for the markets. ${ }^{24}$

Although the tug-of-war between the priority of new industrialism or traditional agricultural interests persisted, the organizers of a new exposition embraced both points of view.

\section{Grant Visits in 1879}

In the midst of the National Industrial Exposition, many Louisvillians continued to hold close affliation with activities in the North. Young Thomas Jacob's preoccupation with national politics revolved around the upcoming 1880 presidential election. In particular, he was fascinated by the exploits and future of former President Ulysses S. Grant. In his letters to his brother, each of Thomas' references to Grant expressed hope that Grant would run for a third term which is curious since the Jacob family was Democrat. The admiration for Grant and the fact that he expressed it openly and often to his brother may indicate that the family affiliation with the Democrat Party was more for political expedience and pragmatism rather than deep-seeded views. Or, perhaps, the Jacob family's loyalties rested with the New Departure Democrats. However, the notion of timid loyalty to party is supported when one considers that Charles D. Jacob, in an unsuccessful attempt at a fifth term as mayor, ran as an independent.

Nevertheless, Grant was at the top of young Thomas Jacob's mind when he began writing his brother as one of the first items that he mentioned related to the former

24 "Our Cotton Exposition," Courier-Journal, 24 October 1872: 4. 
President. He wrote:

By the way, General Grant had a big reception in Chicago. Mayor Harrison of that city delivered on his own accord, a lecture to Grant on the third term business. He said that Grant ought to follow Washington's example and refuse a third term. He will be here about the first of December. There will be great ado over him here. ${ }^{25}$

General Ulysses S. Grant, Commander of the Union Army and former Republican President, visited Democrat controlled, ex-Confederate filled, Louisville, Kentucky and a great ado over him did occur.

On May 17, 1877, former President Ulysses S. Grant and his wife Julia left Philadelphia for a vacation in England. Following a grand reception by the English, the Grants extended their journey. Two years later after touring Europe and visiting the leaders of nearly all the crowned heads of Europe and Asia, the Grants prepared for a long Pacific voyage home. The exploits of the Grants and their raucous receptions from the foreign public and dignitaries fascinated the American press. Newspapers from across the nation trumpeted reports of the adulation shown to the former President and Civil War hero. Historian and Grant biographer, William S. McFeely, suggested that the conclusion of the trip did not fit into Grant's design. Grant intended to travel from Tokyo, Japan to Australia but steamship schedules could not accommodate his desires. Although Grant had steadfastly denied any inclination to return to the White House, McFeely asserted

${ }^{25}$ Thomas Prather Jacob, Jr., Letter, 10 November 1879, John Jeremiah Jacob 1861 - : Letters to Him From Brother Thomas Prather Jacob, Jr. During Trip to Europe 1879-1880, Filson Historical Society, Louisville, KY. John Jeremiah Jacob traveled to Europe with his uncle, former Louisville Mayor Charles D. Jacob, from late 1879 to mid 1880. Thomas Prather Jacob, Jr. corresponded with his older brother on numerous occasions during the time period. Though the younger Jacob was but 13 years old, the letters reveal a great deal of detail regarding every day life in nineteenth century Louisville. Hereafter cited as Jacob, Jr., Letters. 
Grant's extended absence from America came about as a political ploy to gain the Republican nomination for the 1880 presidential election.

Grant planned his homecoming just prior to the June 1880 Republican Convention and he hoped to ride the wave of popularity induced by favorable press from abroad, to the nomination. ${ }^{26}$ In the introduction to his Memoirs, Grant noted that "man proposes and God disposes" and in that vain, one might conclude that Grant would view the lack of steamships from Tokyo to Australia as an act of Divinity. ${ }^{27}$ In fact, McFeely referred to Grant biographer William B Hessletine who opined that had Grant "delayed his return for six months, he might have received the nomination in 1880." Instead, the Grants arrived in San Francisco nine months before the convention. While Grant's political instincts proved correct and his popularity did carry across the ocean back home, McFeely maintained that a campaign based solely on enthusiasm and popularity was difficult to continue. Slowly, Grant made his way from San Francisco across the continent from city to city in a political campaign thinly disguised as merely the final leg of his global excursion. The momentum of his triumphant return persisted until he reached Chicago on November 13, 1879.

The occasion was a reunion of the Army of Tennessee and Samuel Clemens joined in the celebration as a speaker. Clemens' oration was filled with classic humor and the crowd roared with approval. However, McFeely pointed out that Clemens was a Democrat and, in classic Mark Twain style, shrouded a sarcastic underlying theme with humor. Clemens began with a toast to babies. He then

\footnotetext{
${ }^{26}$ William S. McFeelly, Grant: A Biography (New York: W.W. Norton, 1982), 478.

${ }^{27}$ Ulysses S. Grant, The Personal Memoirs of Ulysses S. Grant (New York: Smithmark, 1994), 8.
} 
added, "when the toast works down to the babies, we stand on common ground." He continued by describing Grant, who as an infant, had the goal of getting his big toe into his mouth. Clemens said that goal was one the guest of honor had begun some 56 years prior "and if the child is but a prophecy of the man, there are mighty few who will doubt that he succeeded." The story was received overwhelmingly well, but McFeely suggested that it was politically destructive as it mimicked the tale of the Emperor's new clothes. Clemens painted a picture of Grant, naked in the cradle, exposing the nakedness of his attempt to regain the Presidency. McFeely observed there was no substance to Grant's campaign and a candidate so easily reduced in image to that of a naked baby in a cradle could not possibly win an election. Grant presented no ideas or issues and McFeely analyzed Clemens' underlying theme as Grant simply trying to put his foot into his mouth and in that endeavor, he would succeed. ${ }^{28}$ The implication that Clemens' speech revealed the emptiness and futility of Grant's campaign might suggest the quest was over. Although McFeely makes a strong argument that Clemens had put the dagger into Grant politically, nothing suggests that Grant did not remain popular. Grant continued on his tour of the nation after Chicago and found that the former stronghold of the Union army, Louisville, welcomed him as a returning hero, in spite of his Chicago skewering.

From Chicago, Grant went to Indianapolis and then directly to Louisville, ignoring the fact that Louisville and Kentucky's political structure remained in the hands of the Democrat Party. The fact that the campaign did not go farther south than Louisville suggests that Grant and his supporters considered Louisville to be

${ }^{28}$ McFeely, Grant, 480-81. 
a northern city. The city had, after all, been the base of operations for the Army of the Ohio and the state had remained loyal to the Union. However, six days prior to Grant's Louisville arrival, the Central Catholic Advocate published an article that suggested Clemens' views were not just his own. An interesting aspect to the article consists of the headline, "The Southern Phase of the Grant Boom." The headline itself confirms that Grant enjoyed a tide of popularity while at the same time revealing the editors of the Advocate considered Louisville as part of the South. The text begins by saying "If ex-President Grant had any wisdom he will retire from the plots of his friends and supporters to return him for a third term. Ex-President Grant has had his full share of public honors in every part of the world, and he may rest assured that if he becomes a candidate for President again it will not result as that he may congratulate himself." The $\underline{\text { Advocate }}$ went on to say that many Republicans oppose his nomination and that the "German element of that political body is not in favor at all of the third term and the cry that the South is on his side is hollow." The article is not clear whether or not the reference to the German population reflected the views of the growing German immigrant population in Louisville or if the paper was attempting to influence the German vote, or both. Nevertheless, it did detail the reference to southerners, suggesting that Confederate heroes like "Longstreet and Mosby" supported Grant in hopes of patronage appointments to office so that they may "hold on the public purse." The Advocate concluded that "these patriots would support anyone who would give them a Quid pro quo" and southern supporters had fallen victim to "bread and butter Republicanism, which has won over these fiery heroes to the 
Grant wing." It was hoped that the support of famous southerners combined with northern Grant supporters would overwhelm the opposition in the Republican Party to a third term. ${ }^{29}$ The reference to former Confederate General James Longstreet and Virginia Cavalry Colonel John S. Mosby indicates the paper's editorial judgement fell in line with "Lost Cause" ideology as both Longstreet and Mosby resisted "Lost Cause" mythology, advocated economic development and supported the efforts of Watterson's New Departure philosophy. ${ }^{30}$

Perhaps not surprisingly, the Advocate did not cover Grant's visit. However, another Catholic paper, The Record, in its December 15, 1879 issue, printed excerpts from coverage of Courier-Journal. ${ }^{31}$ Henry Watterson's Courier-Journal and Robert Kelly's Commercial both provided extensive coverage of Grant's visit. Although Watterson supported the Democrat Party, the day prior to Grant's arrival, the Courier-Journal reviewed Grant's entire world tour leading up to his arrival. Kelly followed suit, though his coverage of the world tour was less elaborate and focused instead more on the details of the events in Indianapolis. Coverage from both papers of the visit itself was remarkably similar as the day was simply reported chronologically with the complete transcript of each speaker's words. The day was cool and frequented by rain as the official rainfall total for December 10, 1879 in Louisville totaled $1.18^{\prime 32}$

Inclement weather and a train that was an hour late arriving from Indianapolis could not deter Louisvillians from greeting Grant. The Courier-Journal reported

\footnotetext{
29 "The Southern Phase of the Grant Boom," Central Catholic Advocate, 4 December 1879: 4;

${ }^{30}$ David W. Blight, Race and Reunion: The Civil War In American Memory (Cambridge, MA: Belknap Press, 2000), 293.

31 "How Kentucky's Chief City Honored General Grant," The Record, 15 December 1879: 8.
} 
that spectators began filling the streets three hours before Grant's arrival and though rain

poured down in torrents, not a whimper or murmur was heard; not a soul left the spot or quarreled with the cruel clark of the weather. There were women and girls, men and boys, mothers with infants in their arms, brothers holding younger brothers by the hands, sisters leading sisters, country people and village people and city people. There were Americans, Englishmen, Germans, Irishmen and colored folks. In fact everybody was there with his sisters and cousins and aunts, and everybody thought of but the one thing-of catching a glimpse of the distinguished ex-President and sending up a cheer of welcome to gladden his morning. ${ }^{33}$

Dignitaries from around the state, including the Democrat Governor Luke Pryor Blackburn and Louisville's Democrat Mayor John G. Baxter, made speeches and greetings to Grant, who responded to each in kind. With such fanfare and adulation for the man who had vanquished the Confederacy and whom many southerners considered to have ruled over a heavy-handed Reconstruction policy, it is hard to say that Louisville was a "southern city" in 1879. To further the argument that the city had not yet shed its northern ties, one must consider that a delegation of Blacks was allowed to speak and greet Grant on the same stage as the other dignitaries. The delegation's representative gave a short, but focused monologue dealing with the rights and nobility of citizenry. The speaker was only identified as Mr. Morris. Morris referred to the admiration he held for Grant and the reception he received around the world as Grant "always maintained the true dignity and nobility of the American citizen." Morris advanced the idea that Grant's place as a "plain" American citizen "dwarfed" of

32 “Grant," Louisville Commercial, 11 December 1879. 
Czars, Kings and Emperors. Morris went on to include black Americans in the same category as Grant when he said:

Our proudest boast is that we too are Americans, citizens of this great republic, the wonder and admiration of good men and true the whole world over. We hope for the day when the disabilities which envtron (sic) us because of our former condition will have passed away and in which we can truly enjoy all the blessings and dignities which of right belong to the citizens and which your process made possible. ${ }^{34}$

No papers reported any derision from the crowd nor indignation from anyone.

Instead, Grant responded, "I am very much obliged to the colored citizens of Louisville for their words, and express the hope with them that all the rights of citizenship may be enjoyed by them as it is guaranteed to them already by the law and constitutional amendments; and I think the day is not far distant when, without any embarrassment whatever, they will, by common consent, enjoy unmolested and freely every right to judge conscientiously of the suffrages that they want to exercise wherever they will live, and, in all respect, to be free and equally independent before the law." ${ }^{35}$

At five o'clock, Mrs. F.D Faulds held a reception for Mrs. Julia Grant at Mrs. Fauld's elaborate home on the corner of Sixth and Walnut Street that was attended by numerous guests. Conspicuously absent from the Commercial coverage was Grant's dinner held at the same time at the home of Henry Watterson. Watterson's private reception for Grant appears on the surface as odd since Watterson was an ex-Confederate, a staunch Democrat and vehemently anti-Grant in his editorials.

\footnotetext{
33 "Well Met," Courier-Journal, 11 December 1879.

34 "Well Met," Courier-Journal, 11 December 1879.

35 "Well Met," Courier-Journal, 11 December 1879.
} 
However, the reception for Grant reinforced Watterson's advocacy of his New Departure strategy of complete reconciliation with the North and acceptance of all constitutional amendments. The reception also reveals Watterson's duplicity. While he received the former President and Republican, Watterson had also been recruiting Blacks to the Democrat Party who almost universally voted Republican. Watterson felt that only by supporting the party in power would Blacks gain the acceptance they desired and receive the full benefits of the political process. While duplicitous in his political courting of Grant, he showed his sincerity regarding the plight of Blacks by pushing for equal access to public transportation to Blacks in Louisville. ${ }^{36}$ Nevertheless, Watterson had written scathing editorials condemning and ridiculing Grant throughout his administration and had avoided meeting the General at all cost. Watterson explained in his autobiography that every time he was offered an opportunity of a meeting he declined because "I know that I shall fall in love with General Grant. We have a rough presidential campaign ahead of us. If I go down to the seashore and go in swimming and play penny-ante with General Grant I shall not be able to do my duty." Obviously, Watterson did not take seriously the prospect of a Grant third term, as it was Watterson who invited Grant to dine with him. Watterson's personal instincts proved true as following his dinner with Grant, the pair visited often in Grant's New York office and they became good friends. Watterson said of Grant: "He was the most interesting of men. Soldierlike-in his official and business dealings he threw aside all formality and reserve in his social

\footnotetext{
${ }^{36}$ Joseph Frazier Wall, Henry Watterson: Reconstructed Rebel (New York: Oxford University Press, 1956), 93.
} 
intercourse, delightfully reminiscential, indeed a capital story teller. I do not wonder that he had constant and disinterested friends who loved him sincerely."137

The recollection of the editor of the Memorial provided a possible hidden reason for the acceptance of Grant by Watterson and Louisvillians in general, despite his political skewering by Clemens. J. Stoddard Johnston wrote in 1896 that a general feeling existed that Grant may emerge as a "non-partisan" candidate. The hope was that he would stand for union, fraternity, and peace between the former belligerents of the Civil War. Though Johnston did not use the term, it may be interpreted as a brief description of someone involved in Watterson's New Departure efforts. Johnston recalled that many people, fearing political implications, grew concerned about the type of reception Grant should receive. Any trepidation fell away and the former president received the full welcome described by the papers. However, Johnston adds evidence that the ceremony may have been part of an overall New Departure scheme. At one point, the former Union General received an escort of "ex-Confederate soldiers, composed of the most prominent citizens, who marched on foot in the procession." Orchestrated or not, the visual symbolism of unity and reconciliation must have pleased Watterson and Grant. Johnston attributed the escort as testimony to the esteem in which Grant was held by the ex-Confederates for the "magnanimous treatment of Robert E. Lee at the close of the war." ${ }^{38}$ Johnston's explanation suggests the action fit closely with "Lost Cause" sympathies.

${ }^{37}$ Henry Watterson, Marse Henry: An Autobiography Vol. I (New York: Beekman Publishing, 1974), 212-214.

38 J. Stoddard Johnston, Memorial History of Louisville From Its First Settlement to the Year 1896 Vol. I (Chicago and New York: American Biographical Publishing Company, 1896), 110. 
However, Watterson's prominence in the activities as the host for a private dinner with his old Civil War and post-war political rival indicates that much of the ceremony involved with Grant's visit arose from Watterson's New Departure ideology. Pehaps in response to the success of the visit of Ulysses S. Grant to Louisville, exactly two years later on December 10, 1881, ex-Confederate President Jefferson Davis made a less celebrated visit to the city. ${ }^{39}$

Not everyone felt compelled to glorify Grant's visit. The Advocate printed two stories in its December 18, 1879 edition regarding Grant. Page three featured the complete text of Clemens' sarcastic baby story from Chicago in an article titled, "Mark Twain on Babies." Page four followed with a scathing rebuke of Grant and the Republican Party. It began by saying, "there is a great deal of money at the bottom of Republican politics in the United States, and very little patriotism." The article concluded that Grant "is not a politician like Patrick Henry, or Madison, or Jefferson, in the political arena because he can serve the country. No; he is there because there is money in it and every cheer given for him is a cheer for money. He makes no pretense about that matter and in this he is beyond the average Republican who lives on pretense. He is a star Republican who never was honest in anything in politics except in using them for money, and Republicans are right to their stripe when they adopt him." ${ }^{40}$

The Advocate erred in at least one aspect of its editorial: Grant did not receive the 1880 Republican nomination for a third term. In June 1880, Thomas Prather

${ }^{39}$ R.C. Riebel, Louisville Panorama: A Visual History of Louisville, $2^{\text {nd }}$ ed. (Louisville, KY: Liberty National Bank \& Trust Company, 1956), 108.

40 "Mark Twain on Babies," Central Catholic Advocate, 18 December 1879: 3; "The Republican Stripe," Central Catholic Advocate, 18 Decmber 1879: 4. 
Jacob, Jr. dutifully reported to his brother the bad news:

I suppose you know that James A. Garfield and Chester A. Arthur were nominated by the Republicans. This killed Grant. I hope that Seymour and Tilden will be nominated by the Democrats-I think we have a pretty good chance of electing our President. Hon. Alex H. Stephens said that the Republican ticket is the worst they have nominated for twenty years. ${ }^{41}$

The gloomy report overseas to John J. Jacobs notwithstanding, Garfield and Arthur won the election. Following Garfield's death in 1881, Chester A. Arthur became the twentieth President of the United States. Like Grant, Arthur too would make a memorable visit to Louisville.

\section{The Southern Exposition}

Given that the city had put forth such effort and had success in marketing the 1872-1882 Grand National Industrial Exposition on large and grandiose scale, it stood to reason that the new exposition had to surpass the previous exposition in all facets. Further, in 1881, Atlanta had presented its Cotton Exposition with great fanfare. To gain the attention, respect, and understanding of Louisville as a southern city without peer, the previous exposition could not overshadow the new declaration. Louisville business and politicall leaders clearly stated their new selfdetermined identity by calling the exposition of 1883, "The Southern Exposition at Louisville." The Southern Exposition was the turning point in Louisville's transition from a northern industrial city to an important southern urban center.

Initially, organizers determined the necessity of the physical structure had to 
surpass that of any previous endeavor to create the illusion of grandiosity. The Committee on Organization appointed Board of Trade Superintendent, Maj. J.M. Wright, as President and manager of the Southern Exposition. To finance the project, organizers created a public company similar to the one established for the previous exposition. The company issued shares of stock valued at twenty-five dollars with a capitalization limited to five hundred thousand dollars. ${ }^{42}$ Initially, the corporation comprised one thousand seven-hundred thirty-two subscribers with a total investment of two-hundred fifty-eight thousand dollars. ${ }^{43}$

Organizers marketed the Southern Exposition so well that the, decade long, National Industrial Exposition has been almost ignored by previous historians and histories of Louisville. Scarcely was the Grand National Exposition mentioned in the historiography of Louisville, including the Memorial History of Louisville. However, virtually every author dealing with Louisville's development covered the Southern Exposition. The viewpoints of the significance vary. Tapp and Klotter mentioned the three-hundred thousand dollar, thirteen acre central building of the exhibition without further detail except that it housed "1500 agricultural and mineralogical exhibits." They concluded that the exposition "proved to be one of the most effective means of advertising the resources, hospitality, and charm of Kentucky to that time." ${ }^{14}$ Other works focus on the compelling nature of the building itself, which was a two story complex with dimensions of nine hundred by six hundred feet. It featured carriage, sawmill and

\footnotetext{
41 Jacob, Jr., letters, 16 June 1880.

42 "The National Exposition," Courier-Journal, 21 October 1872: 6.

4. Tapp and Klotter, Decades of Discord, 100.

44 Tapp and Klotter, Decades, 101-02.
} 
boiler annexes as well as an art gallery, restaurant, and pavilion. The highlight of the structure, and perhaps the entire exposition, was born by a twenty-one boiler, two-thousand two-hundred twenty-five horse power engine that powered machinery for exhibits as well as four-thousand six-hundred incandescent light bulbs! Thomas A. Edison had invented the light the previous year and the installation of lights was the greatest collective display in human history to that time. The total number of incandescent bulbs in the main Southern Exposition building exceeded the number of incandescent lamps in New York City. ${ }^{45}$ Singularly, the incandescent illumination of the Southern Exposition provided a local and national attraction. Louisville historian Melvin O. Briney said that the sight was so breath taking that families visited almost daily and "the miracle was always the same. ${ }^{146}$ Wade Hall and Nancy Jones pointed out in Louisville 200: Reflections of a City that a Louisville magazine editor found the Edison light as the grandest exhibit of all.

\begin{abstract}
While we rest, the dusky shadows of the twilight come creeping out in weird, uncanny shapes gathering more and more closely about us. Suddenly, a soft delicious radiance falls over us-shines through us, until we feel like a wee, glad hearted child opening its merry eyes to the sunshine. We look around us in surprise, for low! the whole building is flooded with beautiful brightness dropping thousands of tiny incandescent horse-shoes ... a healthy eye can look straight at it and feel no pain. More wonderful still, it gives out no heat, absorbs no oxygen, so that after hours in this crowded, brilliantly lighted building, the air is as pure as if it were sunshine itself. ${ }^{4}$
\end{abstract}

45 George H. Yater, Two Hundred Years at the Falls of the Ohio: A History of Louisville and Jefferson County, $2^{\text {nd }}$ ed. (Louisville, KY: The Filson Club, 1987), 121; Riebel, Panorama, 146.

${ }_{46}$ Melville O. Briney, Fond Recollections: Sketches of Old Louisville (Louisville, KY:

Louisville Times, 1955), 104.

47 Wade Hall and Nancy Jones, Louisville 200: Reflections of a City (Louisville: Hamilton Printing Co., 1978), 54-55. 
Using Edison's sixteen candlepower lamps brought the Southern Exposition national exposure and acclaim beyond that of any competing expositions. Nevertheless, organizers created greater national attention by inviting President Chester Alan Arthur to open the Southern Exposition on August 1, 1883.

The inaugural Southern Exposition ran for one hundred days and was held annually through 1887 . It featured over 1500 exhibits, which the Memorial described as covering "every variety of product and manufacture" and notes the quality of the textile machinery on display as well as art displays on loan from "Eastern connoisseurs." The Memorial concludes that the exhibits of Kentucky's natural resources of timber, minerals and agriculture held the most "practical merit" as it claims they resulted in "large investments in the State by capitalists from other sections. ${ }^{48}$ The assertion of successful outside interest in the exposition verified the intentions of the organizers in a pamphlet. The original intent was stated as "bringing the industries and products of the North and South face to face. ${ }^{49}$ As had been the case with the previous exposition, organizers touted Louisville's geographic location.

The Industrial News pointed out that the latest census determined Louisville as the population center of the United States with fifty million people living equidistant from the city. The publication expected the exposition to result in an expansion of local manufacturing, which it described as working at capacity at that time. It claimed that "since the lavish opening of all lines of industry in the

48 Johnston, Memorial, 110. 
South, the machine shops of Louisville have increased in a ten-fold ratio in size and number" to a degree that machinists had difficulty keeping up with demand. Although the Industrial News featured numerous articles and advertisements emphasizing the virtue of Louisville manufacturing, it did not fail in mentioning Louisville's association with the South. An article reviewing the Alabama exhibit stated that, "There are few exhibits in the Exposition more worthy of careful consideration by everybody than that made by Alabama." It explains the display was of particular interest to Kentuckians since the development of the minerals, agriculture, stone and marble of Alabama largely was the result of Kentucky investment and dismisses the value of any Northern efforts.

It is a fact that Alabama's wonderful development has been accomplished without the aid of Northern capital. In this simple statement, there is nothing intended to reflect upon those states that have benefited by the influx of Northern wealth, skill and ideas. But there is a just pride felt by the Alabama people in the state... That great corporation, the L \& N and G.S.R.R. pushing a way to the Gulf, found it necessary to take interest in the state that formerly occupied a modest position in the list of Southern states. They discovered a great uncultivated field before them. A few years later, the lands began to yield their coal and iron; the smoke from great furnaces and foundries blackened the sky; hamlets and barren woodlands were succeeded by bustling cities and waving fields of grain. Thousands of hardy workmen skilled artisans and farmers replaced the sparse population of Louisville possessed of energy and capital, became identified with the development of Alabama and today no two states in the Union are so closely wedded in commercial interests as Alabama and Kentucky. ${ }^{50}$

Although the Industrial News made Alabama sound like a barren desert of waste before its rescue by Kentuckians, the case was made that Louisville was not a part

${ }^{49}$ Location of Southern Exposition of Louisville (pamphlet) August 1883. Rare copy found in main branch of the Louisville Free Public Library.

${ }^{50}$ Industrial News, Vol I. Number 12, 21 August 1883, 190-205. Filson Historical Society collection. 
of the North. Capital investment in Alabama and the resulting growth in the industrial and agricultural economy came from their southern neighbor, Kentucky and specifically, Louisville.

In spite of the spectacle and attention that new technology such as grand machinery and miracles of Edison's light wrought, the Southern Exposition did include a formidable agriculture exhibit; an exhibit that focused on cotton. South of the main building stood the Horticultural Gardens, where a "miniature, model cotton plantation" grew in prominent view of all visitors. At the end of each week, the gardens and cotton fields were the gathering place for a concert and "Grand Pyrotechnic Display." Following the fireworks, with the cotton field as a backdrop, the band concluded the evening with its rendition of "Dixie." ${ }^{51}$

The Grand National Industrial Exposition of Louisville helped to promote the city as a manufacturing center. Beginning during Reconstruction and just seven years after the conclusion of the Civil War, the exposition reminded the North, and the nation in general, that Louisville had not been touched by war and was still a formidable competitor for Northern industrial cities. Because of its location, the exposition highlighted Louisville's ability to accommodate those northern interests that desired to do business in the South. Although historians have ignored the ten-year exposition, its importance lies in the transition of the definition of Louisville. The exposition fit into Henry Watterson's New Departure scheme of creating an atmosphere of unity with the North, while at the same time promoting the industrial development of a new South. In the 1870's, Louisville established itself as an industrial economic and transportation force on 
par with other northern industrial cities.

After a decade of building relations with the North and courting the South, Reconstruction had ended and Louisville stood poised to break its longstanding traditional acceptance as the nation's southern most industrial city. But in doing so, exposition organizers did not abandon the ideals of the New Departure. In June, 1883, prominent Louisvillians such as Charles D. Jacob and Henry Watterson along with exposition officials made a promotional trip to New York. Businessmen in New York held a dinner to honor the "southern guests," where exposition chairman F. D. Carley said, "the new south, rejoicing in its fertile fields and its varied products has come forth from its unhappy past of slavery and war to devote its energies to the development of the country and the utilization of its hidden riches." ${ }^{, 52}$ As part of the New York delegation, Gen. Ulysses S. Grant responded to Carley's comments by proclaiming that "the exposition will undoubtedly have a great influence in removing whatever sectional feelings may still exist between the people of the South and the people of the North."

Local business and political leaders strategically and consciously chose to define itself as the South's northern most industrial city. The Southern Exposition of 1883 accentuated the deliberate change. It placated "Lost Cause" advocates in the South by providing an avenue in which prideful southerners could claim their growth resulted from their own sectional and cultural efforts. Louisville manufacturing, trade and commercial interests benefited from the southern markets demand for goods and industrial development. The Southern Exposition

52 "The Louisville Exposition," The Washington Post, 8 June 1883; 1. 
stands as the point in time when Louisville chose to become a southern city because of the economic opportunities in regional business. Local business and political leaders exploited Louisville's geographic location, industrial and transportation capacity and re-established its cultural ties to the South. Historians have fully researched the Southern Exposition in its opening year, yet ignored the fact it continued until 1887 because the significance of the exposition resides in the opening year when Louisville declared itself Southern. Though she does not specifically mention the exposition in her 2000 Master's Thesis of the "Lost Cause" in Louisville titled, Louisville and the Lost Cause: Memory; Identity-The Creation of a Confederate City, University of Georgia graduate student Anne Elizabeth Marshall concluded that:

This change in sentiment has had much to do with the way historians have assigned Kentucky a southern identity over the past century. Even recent scholars of Southern history have tended to treat the state as part of the South. ${ }^{54}$

Although the Southern Exposition stands as the focal point of Louisville's transition from a northern, Union, industrial city to a southern commercial, industrial, transportation and trade center, the completion of the alteration was yet to be completed.

53 "The Louisville Exposition," The Washington Post, 8 June 1883; 1.

${ }^{54}$ Anne Elizabeth Marshall, Master of Arts Thesis, Louisville and the Lost Cause: Memory; Identity-The Creation of a Confederate City, University of Georgia, 2000, 2. 


\section{CHAPTER THREE}

\section{The Sixty-Third Birthday of U.S. Grant}

By 1885 , any notion of a political revival of former President Ulysses S. Grant was dead. Grant made a strong bid at the 1880 Republican Convention for nomination to a third term but, in the end, lost to Ohio Congressman James A. Garfield. Grant campaigned for Garfield, who subsequently won the 1880 Presidential election along with his running mate, Chester A. Arthur. Garfield appointed Grant to negotiate a railroad trade agreement with Mexico. Following the completion of the agreement, Grant turned his attention to personal investment and failed consistently. In 1883, he put one-hundred thousand dollars into his son's security firm, Grant and Ward. Less than a year later, Grant and Ward failed in a financial scandal that prompted partner Ferdinand Ward to flee the country. At age sixty-two, the former commander of the Union Army and former President of the United States found himself in drastic financial difficulties. Compounding his woes, he discovered that soreness he had been experiencing in his throat had been caused by cancer.' The news media spread the word of Grant's medical condition and citizens of the nation grew concerned. Perhaps none showed their sympathy more than the people of Louisville. While the 1883 
Southern Exposition marked the turning point of Louisville's self-definition from a northern city to one of the South, the completion of the transition did not occur until April 27, 1885 when Louisville led the nation in a celebration of the birth of Ulysses S. Grant.

By the fall of 1884, Grant, who resided in New York City, knew his illness was terminal. Grant biographer and historian William S. McFeely suggested that the diagnosis prompted the former President to write his memoirs. For several years, other former generals from both sides in the Civil War had published memoirs and personal accounts regarding their experience. Grant, however, had steadfastly refused to do so. But, according to McFeely, the former President's perilous financial condition brought him to a level of humiliation beyond that of impeached President Andrew Johnson. McFeely argued that Grant decided to use his situation to "treat his countrymen to another performance of heroism" by publicly pulling "himself and his family up out of poverty." 2 Grant laid any doubt to his motive for writing his memoirs to rest when he wrote in the preface to The Personal Memoirs of Ulyssess S. Grant:

At the age of nearly sixty-two I received an injury from a fall, which confined me closely to the house while it did not apparently affect general health. This made study a pleasant pastime. Shortly after, the rascality of a business partner developed itself by the announcement of failure. This was followed soon after by universal depression of all securities, which seemed to threaten the extinction of a good part of income still retained, and for which I am indebted to to the kindly act of friends. At this juncture the editor of the Century Magazine asked me to write a few articles for him. I consented for the money it gave me; for at that moment I was living upon borrowed money. The work I found congenial, and I determined to continue it.

\footnotetext{
' William S. McFeely, Grant: A Biography (New York: W.W. Norton, 1982), 88-96.

${ }^{2}$ McFeely, Grant, 493.
} 
The event is an important one for me, for good or evil; I hope the former. ${ }^{3}$

Money motivated Grant not just for himself, but for the security of his family. Aware of his terminal medical condition when he decided to write his memoirs, Grant concluded his opening remarks by conceding that at times while writing he was "reduced almost to the point of death." ${ }^{4}$ Although aware revenues from booksales would not likely occur until after his death, he showed great determination in his effort to complete his memoirs. McFeely stated the logic of his determination was simple: "He was performing this task to support the family, and, of absolute essential importance, there was fulfillment for him in the nature of the job itself."

As much as book publishers had perceived the public's desire for the thoughts on the Civil War from the former Union Commander, newspapermen across the nation grew more concerned with the General's health. Throughout the fall of 1884, rumors swirled that Grant was ill. Grant inadvertently confirmed the rumors when he wrote an acquaintance that his "painful throat made it impossible to keep an engagement in Hot Springs." The acquaintance promptly released the personal note to a reporter and the news of Grant's condition spread across the nation. Though the patient never used the word, "cancer" was the speculation of the scribes. From that point forth, the American public received nearly daily updates from their local papers as reporters converged on the Grant home. McFeely writes of the spectacle:

\footnotetext{
${ }^{3}$ Ulysses S. Grant, The Personal Memoirs of Ulysses S. Grant (New York: Smithmark, 1994), Preface.

${ }^{4}$ Grant, Memoirs, Preface.
} 
In a century that relished the spectacle of dying there was, in America at least, no deathwatch equal of Grant's. Lincoln's had been dramatic and immensely affecting, but it had also been tragically brief. With Grant, the nation for eight months read almost daily in the newspapers of the progress of the disease, of the devouring of the victim by the unmentioned cancer, and of the valiant battle of the old warrior, before getting the news of his final surrender-or victory-depending on the reader's theology. ${ }^{6}$

Grant received words of encouragement and good wishes from people around the country. A simple note from Dan McCauley, who was one of thousands of men who served under Grant in the Civil War, reflected the regard in which citizens held Grant and the affection of many of his former soldiers:

Pardon just a line of interruption-I ask for no answer-your waste basket is handy I trust "trimmed and burning."

Merely this: If you could only realize how affectionately and lovingly your every hour is regarded by all people of all conditions, but more particularly your old Soldiers, you would be a very happy man.

May God bless you and keep you with us in health and satisfaction for all the years you wish to stay.

$$
\begin{gathered}
\text { Affectionately your Old Soldier, } \\
\text { Dan McCauley } \\
11^{\text {th }} \text { Indiana }
\end{gathered}
$$

News of the former President's condition came to Louisville and the papers covered it as their national newspaper brethren. The Courier-Journal provided daily updates, often on the front page. On March 1, 1885 a headline read, "General not know; Fred and Jesse admit it is fatal (or will be)." At the end of the month Watterson's paper ran a story from Denver, where a reporter recalled an on-board train interview he conducted with Grant some years before. The

\footnotetext{
${ }^{5}$ McFeely, Grant, 504.

${ }^{6}$ McFeely, Grant, 502,509.
} 
reporter used his story to support his admiration for the former President. By early April, the Courier-Journal confined its reporting to daily updates on the patient's condition. April 5, 1885 brought an article on page two claiming that Grant's condition was "unchanged" and a week later, again on the second page, the paper declared that doctors' opinion on Grant's prognosis was "divided." A separate column discussed the probability of Grant's burial at West Point. ${ }^{8}$

The Louisville Post covered Grant's illness in more measured terms. The Post started the new year off with a January 1 article, of moderate length, that outlined the efforts of Grant's "rich friends" to raise funds on the General's behalf to retire a one-hundred thousand dollar loan made to Grant by W. H. Vanderbilt. ${ }^{9}$ Through March, the Post gave sporadic reports that often consisted of a few sentences. On February 28, 1885 an article appeared that read, "Colonel Fred Grant stated to a reporter that the Gen. Grant was a very sick man and there was no longer any use of denying it. He had kept his true condition a secret to prevent the house from being overrun with callers. The General is confined to his bed. There has been a great throng of visitors all day but none were admitted." ${ }^{10}$ At the end of March, the Post followed a March 30 short article concerning Samuel Clemens, who perhaps ironically was Grant's publisher, not entering the Grant home because the patient's condition was "precarious," with another in which the paper compared Jefferson Davis to Grant. The March 31 report insinuated that

\footnotetext{
${ }^{7}$ Dan McCauley, personal letter to Ulysses S. Grant, 15 March 1885, Filson Historical Society, Louisville, KY. Miscellaneous catalog.

8 "General Not Know; Fred and Jesse Admit It's Fatal(or will be)," Louisivlle Courier-Journal, 1 March 1885: 2; "Old Reporter's Recollection of The Dying Soldier," Courier-Journal 27 March 1885: 8; "Unchanged," Courier-Journal 5 April 1885: 2; "Divided Opinion," Courier-Journal 12 April 1885: 2.

9 "Grant Fund Raised," Louisville Post, 1 January 1885: 1.
} 
the former Confederate President was nearly as sick as Grant. ${ }^{11}$ After April 1, 1885, when the Post had a headline that Grant had but "hours to live," the paper began to fall in line with other papers and provide lengthier, detailed articles on a daily basis.

The Commercial, kept its coverage regarding Grant's illness muted for the first few months of 1885 . Robert Kelly set up the paper as a Republican organ to compete with Watterson's Courier-Journal and, aside from political differences, the paper's general structure differed in that it featured prominently news-wire reports from around the nation. Many of the stories had little to do with Louisville, but contained topic matter of a salacious nature that might hold the reader's attention. The front page of the January 8,1885 edition featured a small story concerning Grant in the form of a wire story from New York. It consisted a four-sentence paragraph regarding the status of a proposed fund designated for the relief of Grant's debts, followed by a letter from Grant politely declining the offer of assistance. ${ }^{12}$ Just below the story concerning Grant's indebtedness, another wire story from San Francisco ran that detailed the deaths of six men in a tug explosion. ${ }^{13}$ Four days later, a front-page article reflected the efforts of W.H. Vanderbilt to give the Grant one hundred and fifty thousand dollars to retire Grant's debts and the Grants' reluctance to accept. ${ }^{14}$ Wire-reports from various locations such as France, Spain and Wisconsin surrounded the article. The wirereports detailed the acquittal of a French woman accused of killing her "traducer,"

\footnotetext{
10 "A Very Sick Man," Post, 28 February 1885: 1.

" "Grant Worse," Post, 30 March 1885: 1; "Dying" 31 March 1885. I.

12 "For Gen. Grant's Relief," Louisville Commercial, 8 January 1885: 1.

13 "Six Men Killed," Commercial, 8 January 1885: 1.
} 
a hurricane in Spain, and the escape of three men from a Wisconsin prison. An article also highlighted charges made by General William T. Sherman that, during the Civil War, Confederate President Jefferson Davis threatened the state of North Carolina with war if North Carolina attempted to secede from the Confederacy. ${ }^{15}$

At the end of February, the Commercial reported on Grant's health in a short, two sentence article that contradicted rumors of Grant's death. ${ }^{16}$ From the beginning of March forward, the Commercial gave daily updates regarding the health of the prominent patient, but continued to refrain from placing the reports prominently in the paper. The March 10, 1885 health report on Grant came on page two. Kelly determined that his competition with Watterson took precedence because the feature story on page one concerned acidic remarks made by the editor of the Louisville Evening Post toward Watterson. ${ }^{17}$ With reports of Grant's imminent demise on April 1, 1885, the Commercial began to make daily, frontpage reports of Grant's condition in concert with the other papers. The Commercial replicated the Post with its reporting on April 1, 1885 of the rumored parallel demise of Jefferson Davis. However, the following day, the Commercial acted independently when it retracted the report, which it called "greatly exaggerated." ${ }^{18}$ The Commercial also differed slightly from other papers when on April 6, 1885, it printed a short story announcing that Jefferson Davis had written

\footnotetext{
14 "The Grant Memorials," Commercial, 12 January 1885: 1.

15 "General Sherman's Proofs," Commercial, 12 January 1885: 1.

16 "Is Grant Dead,"Commercial, 28 February 1885: 1.

17 "The Death Watch on Grant," Commercial, 29 March 1885: 2; "Sears Secret Hated," The Commercial, 29 March 1885: 1.

18 "A Nation's Dying Hero," Commercial, 2 April 1885; "Jefferson Davis: The Reports of His Demise Greatly Exaggerated," Commercial 2 April 1885.
} 
a letter of sympathy to Grant. ${ }^{19}$

Another Republican newspaper which began publication in 1879, The Louisville Evening Times, matched Watterson's coverage on a daily basis. In late February 1885, the Times printed, in full, a message from President Chester A. Arthur to the House of Representatives in which he accepted on behalf of the United States "in perpetual trust the swords and military (and civil) testimonials lately belonging to General Grant. ${ }^{120}$ Like the Courier-Journal, by April 2, 1885, the Times relegated most of its reporting to the immediate health of Grant:

Gen. Grant passed a very unquiet night. He was continually going from his bed to his chair and back again. He was annoyed at times by attacks of coughing and the accumulation of mucus in the throat. His strength has been maintained by nourishment and stimulents so that his pulse is reasonably steady. At 4 o'clock a failure in the pulse was observed to such a degree that the family were apprised and all soon congregated in the sick-room. He spoke quietly with each member. By the administration of proper stimulents the General soon rallied and is now quietly sleeping in his bed. ${ }^{21}$

Rather than offering a story from a single reporter, often the Times edited together numerous official reports from the doctors at Grant's bedside to form an entire article concerning the President's condition the previous day. The reports often came at hourly intervals and the paper reprinted each in full. Though the CourierJournal reported daily, the Times provided the most detailed coverage of the medical tribulations of Grant. Grant's longtime friend and former military subordinate, Adam Badeau said, "General Grant is sinking rapidly. He may die in an hour and may live 3 or 4 days." A doctor reported that Grant "would probably

\footnotetext{
19 "Jefferson Davis To Grant," Commercial, 6 April 1885.

20 “Gen. Grant's Relief," Louisville Times 28 February 1885.
} 
live through the night" but felt the "greatest danger" resided between the hours of four and five in the morning. ${ }^{22}$

Grant lived through the night and two weeks later, with the nation convinced of Grant's imminent death, the front page of the Times greeted Louisvillians with the headline: "Truly Phenomenal! Gen. Grant Positively Progressing Toward Convalescence; And His Physicians Admitting a Doubt of Thier Diagnosis; Express the Opinion That He Will Recover His Health." Two days prior, the paper reported "he sleeps well, suffers little, but does not gain strength.".23 On April 13, the Courier reported more pessimistic news with claims that the morphine administered by doctors no longer had any effect. The day was referred to as "a sad day." ${ }^{24}$ However, less than a week later, Watterson's paper reported that there had been great improvement and that several physicians questioned the original terminal diagnosis, though it concluded professional opinions had not been altered. But the paper reported that the public's pessimism had degraded and the public doubted the reports of cancer. The Commercial reported that the former President had made "marked improvement." It quoted a doctor as saying Grant's throat was healing and referred to his malady as a "mild form of cancer." 25 April 22,1885 brought articles in both the Post and the Courier concerning a secret new drug from South America that both papers called "a cancer cure." Grant's symptoms had regressed and he had regained his strength such that his nights were uneventful and afternoons included carriage rides. Reporters found the

21 “General Grant:Bulletins," Times 2 April 1885: 2; "General Grant," Times 2 April 1885: 1. 22 "Gen. Grant," Times, 1 April 1885: 1.

2.3 "Truly Phenomenal," Times 17 April 1885: 1; "A Tough Old Soldier," Times 15 April 1885: 1. 
curtains to the general's window open for the first time in weeks. ${ }^{26}$ The general's apparent miraculous recovery prompted some of Louisville's leading citizens to take action.

Little historical record exists regarding the action taken, but on April 20, 1885, Thomas Speed invited several men to his law office to discuss the possibility of Louisville organizing a public celebration of the sixty-third birthday of Ulysses S. Grant forthcoming on April 27, 1885. The Times made the following report of the meeting:

Gen. Grant will be sixty-three years old next Monday, and it is proposed by several prominent gentlemen of this city that, under circumstances, it would be appropriate that this day be recognized in some manner. Gen. Grant occupies a plane far above partisan politics, and about his bed of suffering cluster the good wishes of the people of the whole country. The South vies with the North in expressions of sympathy, and Louisville, a Southern city, can emphasize this feeling in no handsomer manner than by a proposed meeting of citizens, without regard to party affiliations or past difference of opinion. the meeting to-day is only a suggestion; there is no no doubt that next Monday evening it will be an earnest reality, when our citizens will express in tangible form not alone their sympathy with the great and dying soldier, but their appreciation of his distinguished service to his country. ${ }^{27}$

In an editorial, the Courier-Journal similarly announced the meeting with some other remarks:

Gen. Grant belongs now to no party, to no section; he is the Nation's soldier. We may differ, we do differ, concerning his political career, but as a soldier he was brave and generous, faithful to his country, and faithful at all times and under all circumstances to those whome the fortunes of war gave into his hands.

Appomattox is a field to be recalled with feelings of patriotic pride

\footnotetext{
24 "Not So Well," Courier-Journal 13 April 1885: 1.

25 "Gen. Grant's Disease," Commercial. 19 April 1885: 1.

26 "He Takes a Stroll," Louisville Evening Post, 22 April 1885; "A Cancer Cure," Courier-Journal 22 April 1885.

27 Times, 20 April, 1885: 2.
} 
by every American soldier. It, on one hand, marks the close of a struggle as heroic as any people ever made; on the other, it is remembered as the final triumph which was marked at its close by magnanimity rarer than courage or military genius. Gen. Grant gave by his word all the pledges required of those he had conquered, and in the face of bitter partisan passion he maintained the terms of that surrender in letter and in spirit. Appomattox is the field wher both sides conquered, and from it dates the Beginning of a restored Union. ${ }^{28}$

The Post and Commercial made brief announcements of the celebration.

However, notable exceptions to the exuberance of the press regarding Louisville's celebration for Grant came from the local Catholic papers. Neither the Advocate nor the Record made any mention of the planned activities.

No record exists of any other city proposing such an event prior to Louisville. The fact that the Times referred to Louisvlle as a "Southern city" indicates the transition brought about by the Southern Exposition of 1883 had become reality. The Southern Exposition had a second successful year in 1884. A day after announcing the meeting proposing the meeting celebrating Grant's birthday, an article appeared in the Times announcing a meeting of the Board of Trade regarding financing for the 1885 edition of the Southern Exposition.

Nevertheless, in spite of the city's continuing efforts to solidify its national position as a "southern city", city leaders felt obligated to honor the Republican former commander of the Union Army. It may be surmised that Thomas Speed, a Republican and former Captain in the Union Army, organized the meeting since it was held in his law office. Though Henry Watterson was not listed as one of the men who attended the meeting, it is possible that the effort was part of a continuation of his New Departure political movement. His paper referred to 
Grant as "faithful to his country" without clarifying whether "his country" referred to the United States as a whole or merely to the northern states. If the reference pertained to the United States as a whole, it would suggest that Ex-Confederates had not been faithful to their country. Nevertheless, the editorial twice mentioned Appomattox and referred to Grant's "magnanimity" which may indicate the gratitude from Louisville's ex-Confederates of Grant's terms of surrender, in particular how they related to General Robert E. Lee, the centerpiece of the "Lost Cause." The only clear fact is that Louisville, a strategic military city of the Union Army with a heritage of association with the North dating to the colonial era, had made great efforts to associate itself with the South. Suddenly, a week before the day, Louisville decided to commemorate the birth of Ulysses S. Grant, who lay dying in upstate New York.

Louisville's proposition found favor with northern cities of the nation. Henry Watterson attended the festivities of April 27, 1885, in Chicago as a "representative of the South." The Cincinnati Commercial Gazette reported the day as one of national importance:

This is the sixty-third anniversary of the birth of Gen. Ulyssess S. Grant. The suggestion to commemorate it as a national event came from Louisville, where the day will be generally observed, and has been accepted in this as in many other cities and towns in the country. It is undoubtedly the beginning of a new anniversary day in our annals, and is destined to become popular like the 22nd of February or "Washington Day," as it has been happily styled. ${ }^{29}$

Though there is nothing to indicate that the Louisville organizers intended to start

28 "Gen. Grant's Birthday" Courier Journal, 22 April 1885: 4
29 "The Day We Celebrate," Cincinnati Commercial Gazette. 27 April 1885. 
a national drive to commemorate the occasion, their proposition accomplished

that end. The fact that a Cincinnati newspaper gave credit to its rival Louisville is rather remarkable given the historic rivalry between the two cities.

The town meeting in Louisville was held at the Masonic Temple. Unlike the parade and festive atmosphere of Grant's visit in 1879 , the occasion was one of great formality and circumstance. A number of prominent citizens made up a list of speakers. But, before the speeches, formalities such as adopting resolutions and electing officers of the meeting took place. The meeting elected fifty men as vice-presidents and invited to take seats on the stage with the speakers. A motion adopted called for a full report of the meeting "be handsomely printed, and that a copy be transmitted to Gen. Grant." The report was printed and bound by the Courier-Journal and is the only complete account of the momentous occasion. ${ }^{30}$

The official report lists the names of the men who attended the original meeting in Thomas Speed's law office. The names were not listed alphabetically, but instead in an alternating order of affiliation in the Civil War:

\section{Capt. Thomas Speed, Union}

Maj. John H. Leathers, Ex-Confederate

Col. R.M. Kelly, Union

Maj. E.H. McDonald, Ex-Confederate

Capt. J.B. Fishback, Union

Capt. W.R. Abbott, Ex-Confederate

\footnotetext{
${ }^{30}$ The Sixty-Third Birthday of Ulysses.S. Grant. This very rare book was a bound version of the minutes of the entire proceeding, including the text of speeches. Also included are editorials from local newspapers of the day with comments prior to the event and those of the following day. A motion was adopted to have a "full report" of the meeting "handsomely printed," though there is no indication of the publisher's identity. Further, the pages were not numbered. Only six copies are known to exist. One is on display at Grant's tomb and the others in the following collections: Louisville Free Public Library, University of Kentucky Library, Illinois State History Library, Brooklyn Public Library, New York Public Library. All references to the activities and words spoken at the event held in Louisville come from the official record as published. Hereafter cited as Sixty-Third Birthday
} 
John Barrett, Union

Maj. B.F. Camp, Ex-Confederate

James F. Buckner, Jr., Union

Capt. Sam H. Buchanan, Ex-Confederate

Not only were the affiliations noted along with the military rank of each individual, the original committee was made up of an equal number of "Union" men and "Ex-Confederate" men. Those associated with the Confederacy conspicuously noted their former status, perhaps in acknowledgement of their renewed allegiance to the Union. Apparently, the men making the proposition determined on their own the event would take place as the official record states that, "It was unanimously agreed that the day should not be allowed to pass without some expression of respect and sympathy for Gen. Grant." The men then appointed themselves to the Committee of Arrangements with the exception of James F. Buckner and the addition of Col. Lewis Buckner, Maj. John L. Chilton, Capt. A.A. Norris and Maj. J.M. Wright. Maj. John H. Leathers was made chairman of the committee. No indication in the official record or in any newspaper accounts reflects that Louisville's elected leaders had anything to do with, nor approved or disapproved of the plans or intentions of the group of men who met in Speed's office. The ten men simply made a decision to call a town meeting and they determined who would speak, when and where they would speak, and how the meeting would be conducted.

The ritual of the gathering took the form of a formal town meeting, though no publicly elected officials participated. Chairman of the Committee of Arrangements, Maj. John H. Leathers, called the meeting to order. His opening 
remarks concluded by naming Judge H.W. Bruce as permanent Chairman of the meeting. Following Bruce's remarks, a committee on resolution was appointed that, after retiring for conference for several minutes, presented a number of resolutions. No record exists of any vote regarding the naming of Bruce as neither Chairman nor the acceptance of the resolutions presented. Bruce was simply introduced as Chairman by Leathers and the resolutions simply "reported and adopted." After a preamble that described in glowing terms the assemblage of the citizenry and statements of praise for Grant, the committee resolved in part that:

on this anniversary of his birth, the citizens of Louisville do extend to Gen. Ulysses S. Grant their profound sympathy in his illness and suffering, and they congratulate him that his life has been spared, through so great peril, to another birthday.

That the people of our city, in common with our fellow-citizens throughout the land, remember with pride the humanity that marked his military successes, the absolute faith of his military engagements, and that undeviating and resolution with which he illustrated the American character. And bearing in mind the important part he has borne as a public servant, they trust that there may be vouchsafed him a restoration of health, and peaceful and happy years of a green old age.

Bruce read a few letters of some prominent individuals who could not attend the meeting before turning over the podium to a parade of speakers. Thirteen men strode to the podium and delivered relatively short speeches. Although the words spoken came from men described in equal numbers as either "Union" or "exConfederates," a theme of commonality could be heard collectively.

On numerous occasions, the speakers reconfirmed the idea of reunification, which indicates an acceptance of the New Departure ideals espoused by Henry Watterson. The Committee of Resolutions had included in their remarks that the 
men who had fought in the Civil War "to-day, in all honor and all truth, grasp fraternal hands and claim a united country as their own." Colonel John Mason Brown said that a whole people had been unified "by the spread of intelligent and true fraternity and the recognition of greatness and freedom of the strengthened land." Reverend T. T. Eaton declared that "this meeting means a perfected Union." The organizing committee chairman, ex-Confederate Maj. John H. Leathers, interjected the only hint of non-committal to the notion of reunion with the North. He indicated a tendency toward Bourbonism when he said "we gather on this occasion, without regard to party lines or political bias, to bury our differences, at least for the moment."

Several speakers not only spoke of reunion of the nation, but also gave Grant the credit for making the nation whole. Ex-Confederate General Alpheus Baker determined that "no man in the United States who, while he yet lived, could receive such a tribute." Union Major William R. Kinney added, "there is no one whose hand I cannot grasp as a brother, and I think, in a great measure, I owe this gratitude to General U.S. Grant." Federal Colonel James F. Buckner said no one was more generous than Grant in victory and that "his aim was not self glory, but peace to the country." Many of the speakers offered that Grant's greatest contribution to reconciling North and South resided in his actions as the victor and not his tactics as a commander. Second only to references to Grant came those to Robert E. Lee. Holding with the customs outlined with the "Lost Cause" ideology, numerous speakers upheld Robert E. Lee as the symbol of the southern struggle. No one uttered Jefferson Davis' name a single time throughout the 
proceedings. Congressman Albert S. Willis reminded the audience that Grant ignored calls for the arrest of Robert E. Lee and insisted that "the parole of honor given to Robert E. Lee should be maintained." He added that "it was the kindly treatment of Robert E. Lee and of the Southern Army that did more to put down the rebellion than all the guns and cannon that were ever used on the battle field."

In referencing Robert E. Lee, often the speakers echoed the verbiage of Henry Watterson's editorial, which also replicated sentiments of advocates of the "Lost Cause." Specifically and repeatedly, the term "magnanimous" came from the podium. General Baker opined that the public ceremony was "a tribute paid by all our people to a wisdom and magnanimity exhibited by him." Reverend A.A. Willits said that Grant's greatness came from his "wisdom to appreciate the true situation of the hour and the magnanimity to use it for his country, when he recognized in the subdued Confederates not a traitor to be hunted down, but a brother to be conciliated and to be honored." Major Kinney recited a poem in honor of "the magnanimity of General Grant and the chivalry of the Southern soldiers." Judge, and former Confederate Congress member, Thomas L. Burnett referred to Appomattox "where the last touch was given to the completion of that monument to military genius erected by himself, who which all the civilized world did honor when above the 'victor's wreath' he placed on the very apex of that column the sublimest illustration of human magnanimity in declining to receive the surrender sword of the immortal Lee."

Other comments elevated Grant from that of magnanimous conqueror to one in tune with Devine providence. General Baker compared Grant to Jesus Christ 
when he said that Grant was "the commander of the armies of the United States in the greatest Civil War that has happened since the birth of Christ." Reverend Willits compared the Union victory to that of the Romans over the Jews who "came to Jesus Christ and begged him to to go to the house of the Centurion for 'he loveth our nation and hath built us a synagogue."' Willits added "that man, sent to rule over the people, by his wisdom and magnanimity won the hearts of the people he ruled." Willits' verbiage allowed for interchangeability between the adulation of Christ and Grant. Union Colonel Robert M. Kelly implied that predistination dictated Grant's actions when he concluded his speech by saying, "that the gallant men who fought against him should unite in a friendly meeting with those who followed and fought with him, to express sympathy and good wishes for him in this time of his affliction, is the strongest possible testimony that his life-work has been successful and is a nobler complement to him than any attention ever shown him by Kings or courts." General Baker concluded that God's blessings had "reunited our country bonds that civil war will strive to sunder never more."

In spite of the optimistic reports coming from medical reports regarding Grant's condition, the prospect of Grant's imminent demise permeated each of the speaker's remarks. In his opening prayer, Rev. Eaton asked that, in Grant's "sufferings, his mind may stay upon God, and grant when his time has come he can say I have fought the good fight." The Committee on Resolutions included a call for "the citizens of Louisville" to "extend the General Ulysses S. Grant their profound sympathy in his illness and suffering and they congratulate him on his 
life." Meeting Chairman H.W. Bruce stated, "While we all hope for the best, yet we fear the cold hand of Death has already fixed its grasp upon him." Judge Evans was blunt as he said, "our country's greatest living son is stricken, possibly to die" though he included a message of hope by adding, "but faith that he may recover is not extinct." Judge Burnett combined the notion of Devine intervention and reunion with Grant's pending death when he said, "his afflictions have called forth a nation's sympathy. May it not be that this, in the wisdom of Providence, is intended to illustrate in his person the beauties of a reunited, grateful American brotherhood." Federal soldier and judge Walter Evans vowed that "we shall watch over him with the most affectionate of care until he recovers, or, if that is not to be, until he yields himself a captive to that unconquerable foe to which even the stoutest warrior must unconditionally surrender." None of the references to Grant's malaise included the term "throat cancer."

Though not an over-riding theme of the speeches, several speakers referred to Louisvile in its new, self-determined definition. Major Leathers referred to himself as a "humble representative of a Southern city" and Reverend Willits thanked God that he was "able here in a Southern City, without hesitation, to speak with a free heart to an unawed people." Union Captain Thomas Speed exclaimed, "in this Southern city, the proposition to observe this day was first conceived." Congressman Willis implied Louisville's inclusion in the South as he reminded Louisvillians that Grants "magnanimity" and "generosity that stayed the tide of sectarianism that planted in the hearts of our southern brethren those seeds of love that have gloriously grown until now their shade covers the whole 
land." Every speaker, but one, who referred to Louisville did so by including it as part of the South. Ironically, the exception was ex-Confederate General Baker, who gleefully called Louisville, "a great city on the borders of the South."

Only the Courier-Journal printed the transcript of the entire meeting, which took up the balance of the first two pages. The other papers printed excerpts from the event and their coverage was therefore not as extensive as the CourierJournal. All of the reports came with a positive tone, though two days prior to the event the Post blared a headline that contradicted the week of positive reports of a potential Grant recovery. With over-sized, bold-faced print, the headline read, "Must Die" followed by a subheadline, "No Hope of General Grant's Recovery." ${ }^{31}$ The Courier's headline of the day referenced the Grant family's plan to spend the summer at Mt. McGregor, New York and, following quotations regarding how well the general looked and felt, added that the doctors still considered the case terminal. ${ }^{32}$ A common feature of all of the reporting of the Louisville town meeting commemorating Grant's birthday was the mention of the activities in other cities. Though Watterson's absence was known for his participation in the Chicago celebration, the notation of that city's activities did not receive any more mention than those in: New York, Chicago, Indianapolis, Cincinnati, Springfield, Topeka, Washington, DC and Ottumwa, Iowa. The Courier-Journal listed a few details from several cities under the headline, "The Country at Large," which misled the reader somewhat in that none of the cities listed in any newspaper

31 "Must Die: No Hope of General Grant's Recovery," Evening Post 25 April 1885.

32 "Going To Seaside," Courier-Journal, 25 April 1885: 5. 
resided in the old Confederacy. ${ }^{33}$ However, exclusively, the Courier-Journal mentioned that Memorial Day ceremonies in Augusta, Georgia included a speech that recognized U. S. Grant. The Confederate Survivor's Association "unanimously adopted the language" of the oration given by a ex-Confederate Colonel, and the associations founder, Charles C. Jones, who ended his remarks with words that mimicked those by ex-Confederates spoken at the Louisville town meeting:

Remembering him now as the generous victor who, at the ever-memorable meeting at Appomatox, to our immortal Lee and to the heroes of the army of Northern Virginia, on the 9th of April 1865, conceded liberal and magnanimous terms of surrender, do we, standing by the graves of our Confederate dead and mindful of the memories which the observances of this occasion is designed to perpetuate, respectfully tender to Gen. Grant assurances of our sincere and profound sympathy in this, the season of his direful extremity. ${ }^{34}$

The exception to the press coverage, as had been the case leading up to the event, came from the Catholic press. Both Louisville Catholic newspapers made no mention that the ceremony ever took place and appeared to deliberately defy the intent of the celebration. In its first publication following Grant's birthday, the Advocate printed an entire page devoted to the activities of General Braxton Bragg surrounding the Battle of Murfreesboro in 1862. The Record printed a story regarding the nobility and importance of Jefferson Davis as a "colossal figure in American history. ${ }^{\text {"35 }}$

At eight o'clock in the morning on July 23, 1885 Ulysses S. Grant died. But

33 “"The Country at Large," Courier-Journal 28 April 1885; "The Day Elsewhere," Commercial 28 April 1885.

34 "Beside Confederate Graves," Courier-Journal, 28 April 1885. 
the people of Louisville had already led a national eulogy on his birthday, April 27, 1885. Louisville's citizens, who had made a concerted and successful effort to alter its national and international identity to that of a southern city, celebrated the life of the commander of the victorious northern armies. No record exists to suggest the true motivations or intentions of the ten men, Union and exConfederate, who met in Thomas Speed's office on April 20, 1885. Nothing indicates they had a notion that their plans would be replicated in various cities of the nation, especially since the plans arose in less than a week's time. The organizers of Louisville's Grant birthday celebration did not bother to notify nor get the blessing of any local elected officials and nothing indicates any coordination with citizens of other cities. The ten who met in Speed's office simply came up with the idea and appointed ex-Confederate John H. Leathers to lead the organization. Leathers then appointed most of the ten as part of his organizing committee. The reaction of other northern cities to follow up with similar events resulted in Louisville making one final statement that it had been in solidarity with the North. Though Louisville had announced itself as a southern city with the Southern Exposition in 1883, no other city recognized as part of the South made a similar effort. As one of Louisville's most nationally recognized citizens, Henry Watterson attended the celebration in Chicago as a representative of the South. Many of the speeches given by the ex-Confederates at Louisville's town meeting sounded similar to the remarks of "Lost Cause" apologist Charles C. Jones. While no Louisville paper reported any other remarks by those at

35 "Battle of Murfreesboro," Central Catholic Advocate 30 April 1885: 2; "Ex-President Jefferson Davis," The Record 5 May 1885: 4. 
Confederate Memorial Day activities, the possibility exists that other oratories included mention of Grant, given Jones' status in ex-Confederate circles. Historian David W. Blight describes Jones as "an ambivalent irreconcilable" in his zeal to celebrate the Confederacy as a "Lost Cause" advocate. Jones not only wrote several books concerning Georgia's part in the war, he also gave at least a dozen Confederate Memorial Day speeches. ${ }^{36}$ The association between his words and those of the speakers in Louisville indicates that perhaps the motivation of some of the ex-Confederates of Louisville was to carry on the "Lost Cause" mythology of honoring the man whom they saw as giving Robert E. Lee the respect he deserved. One might surmise that the motivation of some Louisville New Departure Democrats was to continue on with the notion that the South had reconciled with the North. Union men in Louisville, no doubt, found their motivation in a desire to celebrate the life of the man who led the North to victory. Regardless of the motivation, the birthday party for U.S. Grant at the town hall meeting held in the Masonic Temple of Louisville marked the final time Louisville recognized its former association with other northern and midwestern cities

\footnotetext{
${ }^{36}$ David W. Blight, Race and Reunion: The Civil War in American Memory (Cambridge, MA:
} Belknap Press, 2000), 42 


\title{
CONCLUSION
}

\author{
Peace has come. \\ God give his blessing on the fact and on the name: \\ The South speaks no invective, \\ And she writes no word of blame: \\ But we call all men to witness \\ That we stand up without shame.
}

\author{
Reverend E.L. Powell \\ Louisville Confederate Monument \\ Corner Stone Ceremony \\ May 23, 1895
}

On May 25, 1895, the city of Louisville laid the cornerstone to a Confederate Monument at the corner of Third Street and Shipp Avenue. Inside the cornerstone lay a box of brass measuring one square foot and six inches deep containing items that "connected with the South's great men and their lost cause." Relics included were a photograph of Jefferson Davis, a partially smoked cigar by Davis, a Vicksburg, Mississippi newspaper from the 1860 's printed on wallpaper and several thousand dollars of Confederate money. ${ }^{2}$ The completed monument, funded by the Kentucky Women's Confederate Monument Association, was dedicated on July 30,1895 . Following the dedication ceremonies, some fivehundred spectators attended a Confederate grave decoration ceremony at Cave

1 "Put in Place," Louisville Courier-Journal, 26 May 1895: 4. Also includes full text of speech by Rev. E. L. Powell.

2 “A Monument Built by Years of Womanly Devotion," Louisville Times, 16 December 1954. 
Hill Cemetery led by ex-Confederate Major John H. Leathers. ${ }^{3}$ Six weeks later, beginning September 9, 1895, the twenty-ninth annual Grand Encampment of the Grand Army of the Republic convened in Louisville.

Louisvillians chose to honor the Confederate soldier around the state's largest Civil War monument prior to the arrival over 150,000 members of the Grand Army of the Republic. Although Louisville had been the base of operations of the Union's Amy of the Ohio during the Civil War and the state remained loyal to the Union throughout the conflict, Louisvillians commemorated their supposed comradeship with the South. Over 108,000 white men from Kentucky fought in the Union Army and another 22,000 black troops joined the Federal ranks. Only 30,000 Kentuckians took up arms with the Confederacy. ${ }^{4}$ Yet, to this day, no memorial to Union soldiers exists in Louisville. When the encampment of the Grand Army of the Republic began, the Courier-Journal featured a nearly fullpage illustration entitled "A Friendly Invasion" as part of its coverage. ${ }^{5}$ Through implication, the paper suggested that the Yankees had invaded the South again, when in fact, the only army ever to invade Kentucky was that of Confederate General Braxton Bragg in 1862.

However, Bragg's invasion was not friendly. Unable to attract any support from neither Louisvillians nor most Kentuckians for his cause, Bragg withdrew from the state following the battle of Perryville in October 1862. Following the battle, the people of Perryville buried the Union dead and let the Confederate

\footnotetext{
3 "Decorated the Graves," Courier-Journal, 31 July 1895: 1.

${ }^{4}$ Robert Emmett McDowell ${ }_{2}$ City of Conflict: Louisville in the Civil War, 1861-1865 (Louisville, KY: Louisville Civil War Roundtable, 1962), 1-2.

${ }^{5}$ Courier-Journal, 10 September 1895: 1.
} 
corpses rot where they lay. ${ }^{6}$ By 1895 , the Union Army had surrendered control of Louisville to the "Lost Cause" and the city rested comfortably the arms of the southern mythology. The Courier-Journal of September 10, 1895 billed Louisville as "the gateway to war in 1861 , is to the Veterans of 1895 the gateway to a prosperous South."7 Louisville had become a "southern city" by choice.

When examining the history of Louisville in the middle to late nineteenth century, evidence suggests that the city has its roots firmly entrenched with the North. Its geographic location of three hundred miles from Chicago makes it difficult to argue otherwise. The city's climate does not fall within the category of Southern states. Winters in Louisville feature snowfalls that often surpass its annual average of eighteen inches and temperatures that often fall below zero degrees Fahrenheit. Consideration that Louisville was once part of the Virginia Colony, a Southern Colony, lends some substantiation to the claim that Louisville began as a Southern settlement but the weight of all other evidence points in a different direction.

Much of Kentucky had little in common with Virginia. By the late eighteenth century, tobacco, a staple crop in Virginia, was but a minor part of the agricultural economy of Kentucky. More central to the economy of the state was the cultivation of hemp, corn, wheat and rye as well as cattle production. The presence of slavery, necessitated by the terms of Virginia's secession of land for

\footnotetext{
${ }^{6}$ McDowell, City of Conflict, 118-19.

${ }^{7}$ Courier-Journal, 10 September 1895: 1.
} 
the state and made possible by the Northwest Ordinance of 1787 prohibiting slavery north of the Ohio River, provided the only true commonality between Virginians and Kentuckians. ${ }^{8}$ Until after the Civil War, slavery formed the only true link between Louisville and the South.

However, the presence of slaves in Louisville did not receive universal embracement in the nineteenth century and did not coincide with the local economy. By 1850, Louisville had become a blossoming city of trade and mercantilism. In order to facilitate the needs of northern industry, merchants and farmers, the federal government bought out interests in the Louisville and Portland Canal Company. Louisville, at the headwaters of the Falls of the Ohio, became a hub for railroads to distribute passengers and freight to eastern and southern markets as well as the western frontier. Mercantilism, manufacturing and livestock production grew in Louisville as a way for the local economy to take advantage of its transportation assets. Agricultural production such as tobacco and cotton, commodities more prevalent in southern states than in Kentucky, used slave labor to fill their labor needs. Kentucky's agricultural labor needs did not require a large slave labor force. Historian Eric Foner asserted that Kentucky had "mostly small farmers engaged in mixed agriculture, rather than staple-producing planters." ${ }^{, 9}$ As an urban center, Louisville had little use for slave labor. Citizens complained of Blacks loitering in the streets. Some Louisville slaves took personal initiative and rented out their services to those who were in

${ }^{8}$ Jennifer Cole, "For the Sake of the Songs of the Men Made Free: James Speed and the Emancipationists' Dilemma in Nineteenth-century Kentucky," Ohio Valley History 4 (Winter 2004) 123; Robert Reid, Always a River: The Ohio River and the American Experience (Bloomington, IN: Indiana University Press, 1991), 72-73. 
need of household chores or to manufacturers in need of labor. Though against the law, White business owners in Louisville, and in other slave-territory cities, made out contracts of specific length, rate of pay, working conditions and a guarantee against injury. Some slaves turned the money earned over to their masters while others kept their earnings for later purchase of their freedom. Many Louisvillians frowned upon the practice, fearing a development of Black entrepreneurial initiative, as well as competition for White labor. ${ }^{10}$

In some regard, the city emerged from the Civil War more divided than in the antebellum days. In the Presidential election of 1861, Republican candidate Abraham Lincoln received just 91 votes in Louisville. However, John Bell of the Constitutional Union Party carried the city by a wide margin, indicating the majority of Louisvillians preferred to support the Union with slavery. ${ }^{11}$ Captain Thomas Speed said that, "the city was ablaze with Union sentiment. Public meetings were held and the most emphatic expressions in favor of the Union were applauded." 12

However, many Louisvillians' attitudes toward the Union soured as thousands of troops filled the city and doubled its peacetime population. Soldiers on leave frequented saloons and brothels and openly associated with gamblers. The citizenry tired of the general bawdy behavior of the troops. Contrarily, every opportunity for Louisvillians and Kentuckians to rebuke the North and join the

9 Eric Foner, Reconstruction: America's Unfinished Revolution 1863-1877 (New York: Harper and Row, 1988), 37-38.

10 Judy Munro-Leighton, Changes at the Falls (Louisville, KY: Portland Museum, 1982), 62 63; E. Franklin Frazier, The Negro in the United States (New York: Macmillan Company, 1949), 594.

11 Reid, Always a River, 2,8. 
South passed without action. On numerous occasions, instead of great anticipation of emancipation from an occupying Union Army, Louisvillians prepared to defend the city from a perceived Confederate attack. By 1865, a series of forts surrounded to city to provide a permanent form of resistance. ${ }^{13}$ Bragg's 1862 Kentucky invasion stood as the only real threat to the city, but guerrilla bands such as those headed by William Quantrill, John H. Morgan, and Sue Mundy provided Louisvillians with consternation. But Louisvillians resented the Confederate raiders as they terrorized and pillaged the people and land regardless of the victim's sympathies. Instead of liberators or heroes, Louisvillians viewed the rowdies as nothing more than murderers and thieves. ${ }^{14}$ Quantrill and Mundy both died in Louisville in 1864; Mundy through public execution and Quantrill from wounds suffered in a battle during his capture. ${ }^{15}$ The argument simply cannot be made that Louisvillians' resented Union soldiers or the actions of the local commanders to the extent that they switched loyalties to the South. When called to action, Louisvillians remained loyal to the North.

However, slavery questions during the war may have carried over to post war days as memories of fear from a Confederate attack and the war's results became clear. Historian Robert Emmett McDowell notes the slavery question became an issue when the 77th Illinois Regiment returned to Louisville on November 19, 1862 following a foray into the South. It returned with a number of slaves who had fled their masters and joined their ranks. Angry masters demanded a return of

12 J. Stoddard Johnston, ed., Memorial History of Louisville From Its First Settlement to the Year 1896 Vol. I (Chicago and New York: American Biographical Publishing Company, 1896), 162.

${ }_{13}^{13}$ McDowell, City of Conflict, 170-76.

${ }^{14}$ McDowell, City of Conflict, 145-169; 176-193 
their property and the army refused. McDowell points out that the event occurred prior to the enforcement of the Emancipation Proclamation of January 1, 1863, and besides, Kentucky was exempt from its effects. Louisville Journal editor George Prentice echoed the views of many Louisvillians when he railed that emancipation broke President Abraham Lincoln's pledge to the country to maintain the Union. Economically, slavery in Kentucky had never been a pragmatic enterprise, similar to other northern states. However, the surplus of slaves in the state made the slave trade "down the river" to southern states more profitable than cattle breeding. ${ }^{16}$ Surplus slaves provided a valuable commodity for slave traders prior to the war. After the war, an influx of Blacks provided further agitation to the White populace when former slaves came to Louisville at a rate of 200 per week. The city's internal support system, already strained with the encampment of thousands of federal troops, cracked as Blacks congregated in whatever shelter they could find. They lacked food and the conditions proved so unsanitary, city officials feared an epidemic. Civic leaders turned to Union District of Kentucky Commander Major General John M. Palmer for relief. Palmer reacted by issuing passes to the North for all Blacks who could not find employment. Thousands of Blacks left the city for northern destinations, including many Louisville slaves who left their owners dismayed over Palmer's actions. $^{17}$

While the slavery issue holds significance to Louisville's history, the issue did not play a major role in the city gaining a southern city moniker. However, the

${ }^{15}$ McDowell, City of Conflict, 193-94.

16 Reid, Always a River, 126-28. 
nation's transition brought about by the Civil War proved to be the catalyst to eventual change. When the state legislature declared loyalty toward the Union in 1861, the North retained a valuable strategic, economic and symbolic asset. Louisville's position on the Ohio River and its status as a rail hub made it an ideal base of operations from the Army of the Ohio. Its industrial and mercantile economy helped provision the western Union armies and communications could be maintained between Washington and operations in the Western Theatre. Following the Civil War, Louisville stood as the southern-most northern industrial city untouched by war. Its infrastructure and economy had expanded during the war as a result of the needs of the army and the city stood poised for further growth.

At the conclusion of the Civil War, Louisville's prosperity made it attractive for veterans and entrepreneurs. Though it had remained a Union stronghold, many of Louisville's political and economic elite returned as ex-Confederates. They found a city bustling with an expanding industrial base, livestock production, and a vibrant mercantile business. The L \& N Railroad possessed the only tracks that connected the North with the South, which gave Louisville an advantage over other northern cities regarding profiting from reconstruction efforts. From 1860 to 1870 , Louisville's population grew by one third and the economic future of the city appeared bright. ${ }^{18}$ But politics entered into the strategy of how the city would move forward. The state had remained loyal to the Democrat party but two factions arose in competition for power in the state and

${ }^{17}$ Reid, Always a River, 200. 
the city. The Bourbons wished for the state to move in a manner that restored the political and economic structure of the commonwealth to its antebellum state. Bourbon Democrats favored a continuance of an agrarian based society and opposed even minimal civil rights for Blacks. Though an ex-Confederate, Courier-Journal editor Henry Watterson surmised that the antebellum days should remain in the past and felt that the South, Kentucky and Louisville should look toward the future through pragmatic realism.

Watterson described the Bourbons as people who "refused to admit that the head of the South was in the lion's mouth and the first essential was to get it out." He claimed that "the Courier-Journal proposed to stroke the mane, not twist the tail of the lion." ${ }^{19}$ However, the political landscape of the state and the nation made his effort difficult. In his analysis, Watterson argued that the Republican Party in Kentucky had not flourished since many former Whigs in the state resented the emancipation of slaves and turned Democrat. The Democrat Party in power, Watterson surmised as, "a body of reactionary nondescripts claiming to be Unionists and clinging, or pretending to cling, to the hard-and-fast prejudices of other days." 20 Watterson determined his best course of action, and the best for the state, was to reform the Democrat Party. With the election of General Ulysses S. Grant in 1868, Watterson anticipated that the Radical Republicans would take charge, dominate Reconstruction, and dictate terms to a helpless South. By conceding civil and legal rights to Blacks, Whites could receive their moral

${ }^{18}$ United States, Tenth Census of the United States 1880: Part II The Southern and Western States (Washington, D.C.: Government Printing Office 1887), 122.

${ }^{19}$ Henry Watterson, Marse Henry: An Autobiography Vol. I (New York: Beekman Publishers, 1974), 173. 
emancipation. Watterson argued that by removing the agitation of the Black equality, radicalism would disappear. Watterson calculated that the best way for the South to avoid harsh repression was "to disarm radicalism by an intelligent appeal to business interests and conservative elements of northern society, supported by a domestic policy of justice alike to Whites and Blacks."21

The discontent regarding Louisvillian's views toward the Union Army concerned the federal government. At the outset of the war, Louisville business had continued a booming trade with the South until Confederate troops confiscated L \& N property and destroyed bridges in Tennessee. Many cities in the North embargoed trade with Louisville as protest as many northerners regarded Louisville businessmen who had profited from early trade with the Confederacy as traitors. In early 1862 , Washington responded by transferring the army's quartermaster duties from Louisville, though the destination of the post is indeterminate. Potentially devastating, the removal of the quartermaster from Louisville proved to be a catalyst for future Louisville expansion. Louisville businessmen responded by forming the Louisville Board of Trade. The commercial organization allowed local businessmen to assert their loyalty, lobby for better relations with northern industrial interests, and work to relax trade restrictions. By June 1863, two hundred twenty prominent business leaders joined the Board of Trade and took the requisite loyalty oath to the Union. ${ }^{22}$

Following the war, the Board of Trade focused its attention on gaining an advantage on its northern competitors. The board lobbied the $\mathrm{L} \& \mathrm{~N}$ for rate

\footnotetext{
${ }^{20}$ Watterson, Marse Henry, 176.

${ }^{21}$ Watterson, Marse Henry, 182-84.
} 
adjustments for shipping costs between Louisville and southern markets and succeeded. The $\mathrm{L} \& \mathrm{~N}$ also engaged in a pooling arrangement with the Western and Atlantic, Nashville and Northwestern and Nashville and Chattanooga railroads which allowed for the intermingling of each companies freight cars at reduced rates. In 1867, the Board of Trade made arrangements with packet lines on the Ohio River in which regularly scheduled barge service to destinations not served by the railroads on the Arkansas and Tennessee rivers. ${ }^{23}$

The actions of the Louisville Board of Trade in the 1860's set the stage for new political developments; the emergence of Henry Watterson's New Departure Democrats. With trade relations with northern industrialists mended and favorable trade terms with shippers for Louisville merchants doing business in the South, the city stood poised for a boom in the 1870 's. Though some industry had flourished in antebellum Louisville, merchant trade dominated. By the late 1860 's, merchants realized the disadvantage with their northern competitors resided in the fact that Louisville was not the source of many finished products. Circumstance required Louisville's industrial and manufacturing base to expand and as it did so, the city reached New Departure goals of Henry Watterson. Despite the efforts of the Bourbons and the fact that many of Louisville's business leaders were ex-Confederates, Louisville grew into an industrial city of trade.

In 1872, as part of an effort to promote the city's industrial and trade capabilities, the Louisville Board of Trade established in The National Industrial Exposition. The city built one of the largest exhibition halls in the nation and held

${ }^{22}$ Reid, Always a River, 130. 
the event annually for the next ten years. The exhibition proved financially successful and attracted business leaders from around the country. Louisville business and industry prospered in the 1870's. Mainly through acquisition, the $\mathrm{L}$ $\& N$ expanded to numerous markets throughout the South and delegations from many southern cities visited the city resulting in new trade agreements.

Louisville historian McDowell stated that at the end of the Civil War:

Louisville was sick of the butchery, sick of the greed of profiteers, sick of the rowdy, drunken soldiers, sick of being treated like an occupied city by the Union of which she was supposed to be a part. She had no experience with Confederate armies. The only real combat soldiers she knew were Union soldiers, and these had been inflicted on her for four years. ${ }^{24}$

McDowell concluded that the Confederates, in the end, captured the city without firing a shot. While his sentiment held some truth, the time frame proposed cannot be supported. Louisville's burgeoning trade with cities of the former Confederacy led to the assumption that Louisville by 1879 was a southern city. But an event in December 1879 contradicted that assessment.

On December 10,1879, near the conclusion of a tour that took him around the world, former Union Commander and Republican President Ulysses S. Grant arrived in Louisville. Thomas Prather Jacob, Jr. suggested in a letter to his brother that Louisvillians greatly anticipated Grant's arrival in Louisville. The city newspapers reported Grant's arrival came with great fanfare including a parade in which thousands of Louisvillians stood in the streets in a driving, cold rain for a chance to see Grant. Henry Watterson, who had written numerous

\footnotetext{
${ }^{23}$ Leonard P. Curry, Rail Routes South: Louisville's Fight For The Southern Market, 1865-1872 (Lexington, KY: University of Kentucky Press 1969), 32-34.

${ }^{24}$ Reid, Always a River, 204.
} 
scathing articles about Grant during his presidency, had steadfastly refused to meet Grant explaining, "I don't dare do so. I know that I shall fall in love with General Grant" fearing that would prevent him from doing "his duty," presumably as a newspaperman. ${ }^{25}$ Grant's tour gave rise to speculation that the former President would seek a third-term Republican nomination in for the 1880 presidential election. Nevertheless, ex-Confederate and Democrat Henry Watterson invited Grant to his home for dinner. Grant accepted and for the rest of his life, Watterson considered Grant a close friend. ${ }^{26}$

Given that the city held the National Industrial Exposition, secured better relations with northern cities, and welcomed with great fanfare the man who led the vanquishing of the Confederacy and led the nation as a Republican, it is difficult to refer to Louisville in 1879 as a southern city. The notion that Louisville had not made the transition to a full alignment with the former Confederacy is also supported when it is considered that Grant presided over Reconstruction and was a potential Republican presidential candidate in 1880 . Louisvillians support for Grant might be attributed to the "Lost Cause" sentiments of some ex-Confederates. New Departure Democrats, like Henry Watterson, may have been continuing their strategy of mending fences with the North. But, overall evidence does not support the contention that Louisville had split from its northern roots.

Little doubt can exist that for nearly two decades following the surrender at Appomatox Court House, Louisville slowly shed its historical ties to the North.

\footnotetext{
25 Watterson, Marse Henry, 212.

${ }^{26}$ Watterson, Marse Henry, 214
} 
The early change in attitude can be attributed to circumstance and public reaction to unanticipated actions by the Union Army, followed by a Republican Reconstruction policy that included constitutional amendments dealing with Black citizenship. Another causation came from the effort and attitude of "Lost Cause" advocates and Bourbons who longed for the mythological days of a Louisville associated with the Old South. Yet, primary driving force resided in economic necessity. Local business leaders recognized that the most expeditious manner for Louisville to grow and prosper rested in exploitation of the rebuilding southern economy. Methodically, over nearly twenty years, Louisville repositioned itself to take full advantage of its assets as they related to the South and contrasted with other northern competitor cities.

Business leaders met their objective by following the political blueprint of Henry Watterson by strengthening ties with northern politicians and industrialists while simultaneously building Louisville's manufacturing base and expanding its trade in new southern markets. The Northern Industrial Exposition ran successfully for a decade and promoted to the nation, and the world, Louisville's economic virtues. But, by the end of the 1870's, the city by the Falls of the Ohio faced a new challenge. After years of lobbying and persuasion, the Cincinnati Southern Railway completed construction of a line directly from the Queen City to Chattanooga, Tennessee in $1880 .^{27}$ The result was that Louisville's chief economic rival and antagonist Cincinnati, as well as other northern cities, could by-pass Louisville altogether and trade directly with southern cities. In 1882, the Louisville Board of Trade determined the time had come to play its trump card. 
Following the close of the National Industrial Exposition in late 1882, local business leaders planned and financed the Southern Exposition. No longer would Louisville promote itself to the world and the nation, but instead Louisville political and economic leaders chose to promote the city to the South and focus on southern markets. Plans included a larger and more elaborate exhibition hall with the largest display of electrical lights in world history. When the exhibition opened on August 1, 1883, visitors came to the hall via an electrified trolley built specifically by the city for access to the exposition. Adjacent to the technologically advanced main hall stood a functional cotton field. Louisville declared to the world it belonged to the South and thereby seceded from the North when it opened the Southern Exposition. With cutting edge technology involving electricity and a booming industrial base combined with traditions of the Old South, the Southern Exposition promoted Louisville as the beacon and gateway of the New South. Adding legitimacy to Louisville's southern claim, and a symbolic blessing from the North, Republican President Chester Alan Arthur cut the ribbon opening the exposition on August 1, 1883.

Louisville historian George Yater described the atmosphere by quoting the Courier-Journal, which exclaimed that, "Louisville scarcely recognizes herselfthere is something electric in the air." Yater pointed out that visitors, editors and special guests from the South and the North saw varied products, machinery, art and attractions from "the Southland." Perhaps significantly, Yater mentioned that when visitors left the hall to walk through the cotton field, they walked in a

${ }^{27}$ Curry Rail Routes South, 138-39. 
southerly direction. The Southern Exposition continued annually through 1887 with the Courier-Journal designating Louisville as the "new Gotham. ${ }^{28}$

In 1883, with its position secure as an industrial city, Louisville broke ranks with the North and took its place in the South with the opening of the Southern Exposition. Perhaps an expression of the nation's acceptance of Louisville's new southern status came through the National Convention of Colored Men. The annual convention was scheduled for September 1883 in Washington D.C. Coincidentally, in September 1883, the United States Supreme court was scheduled to hear a case involving the constitutionality of the Civil Rights Act of 1875. Civil Rights leader Frederick Douglas feared that a convention of Blacks in Washington at that time might negatively influence the court's decision. Two hundred forty-three out of two hundred eighty-two delegates derived from former slave states and Douglas convinced convention organizers that Louisville provided a more hospitable environment for the event. ${ }^{29}$ Though Louisville had formally notified the world as its status of a new southern city, like many ended relationships, a time of lingering attachment with the past occurred.

The close of 1884 brought news to the country that former President Ulysses S. Grant was in distress. Though the Grant family tried to keep the diagnosis from the press, the nation found out the Civil War hero suffered from throat cancer. Like the press in the North, Louisville newspapers covered Grant's medical condition closely. In the early months of 1885 , reports concerning his

${ }^{28}$ George H. Yater, Two Hundred Years at the Falls of the Ohio: A History of Louisville and Jefferson County $2^{\text {nd }}$ ed. (Louisville, KY: The Filson Historical Society, 1987), 121-122.

${ }^{29}$ William S. McFeely, Frederick Douglas (New York: W. W. Norton \& Company, 1995), 314317. 
health maintained a sense of brevity while other articles regarding efforts to raise funds for the Grant family appeared. However, by late March, Grant's health declined and the articles focused chiefly on his deteriorating condition and the opinions of several doctors. Each of Louisville's large newspapers printed daily front-page reports that included an array of speculation regarding the old soldier's imminent demise. However, by mid-April the press expressed great surprise and relief that Grant had apparently made a miraculous recovery. The actions and result of a handful of local Louisvillians to the news might be considered equally remarkable.

Ten business leaders of the city that two years prior had declared itself as a part of the South, met in the office of Captain Thomas Speed to discuss the possibility of commemorating the life of U.S. Grant. No evidence exists of any demand by Louisvillians for such a celebration or any indication that any people in any part of the country made such a proposal; the group of Louisville elites met on their own initiative. Any minutes of the meeting do not exist, but the men who attended equally split between ex-Confederates and those who fought for the Union in the Civil War. They emerged from their meeting with a plan for a town meeting to celebrate the birth of U.S. Grant on April 27, 1885; a week after the meeting was held.

Ex-Confederate John H. Leathers took charge as the chairman for the Committee of Arrangements, which included all but one of the original organizers. It cannot be ascertained if Leathers promoted the event nationwide. Nevertheless, numerous cities in the North followed Louisville's lead and planned 
celebration events as well. Although Henry Watterson accepted an invitation to Chicago's event as a representative of the South, the city symbolically took one last look to its past by leading a mostly Northern celebration of the greatest living hero for the Union. Aside from local newspaper articles announcing the event in Louisville at the Masonic Temple, evidence of any promotion of the town meeting does not exist.

Nevertheless, the Masonic Temple stood filled to capacity on April 27,1885. The town meeting took on a formal nature with the election of a chairman and fifty vice-presidents as well as a Committee of Resolutions. No record exists concerning who participated in either the votes or the members of the Committee of Resolutions. However, the men elected to the largely honorary positions represented the elite of Louisville business community and society. The record also does not indicate the methodology for determining who would speak at the meeting, but eleven men spoke. The Times reported that "each speaker was heartily applauded, and paid an eloquent tribute to the suffering soldier. ${ }^{130}$ The three hour meeting in Louisville concluded with a motion that a full report of the meeting to "be handsomely printed, and that a copy be transmitted to Gen. Grant." Upon unanimous adoption from a "rising vote" by persons unknown, a bound report was made by the Courier-Journal which included editorials from the Courier-Journal, Evening Times, Times and Commercial. Though the number of copies printed remains unknown, only six rare copies survived through the

\footnotetext{
30 “Kind Words for Gen. Grant," Times, 28 April 1885: 4.
} 
twentieth century. ${ }^{31}$

The Cincinnati Commercial Gazette credited its economic rival, Louisville, with the suggestion to commemorate the birth of Ulysses S. Grant. It suggested the celebration took on a national scope, though no cities south of Louisville participated. The paper speculated that the date would take on historic proportion when it called it "the beginning of a new anniversary day in our annals, and is destined to become popular like the 22nd of February or 'Washington Day' as it has been happily styled." ${ }^{32}$ However, the event marked the final time Louisville officially associated itself with the North. Not only did the day not become a national holiday like Washington's birthday, but also Louisville newspapers did not even mention Grant the following year. Instead, on April 27, 1886, the Courier-Journal reported that ex-Confederate President Jefferson Davis arrived in Montgomery, Alabama for commemoration of "Davis Day." Following "Davis Day," the Courier-Journal printed a front-page article that said, "no man in the United States who could have elicited the demonstration that met Mr. Davis. ${ }^{133}$ The extraordinary aspect of the Courier-Journal's statement is that it closely resembled the statement made a year earlier by ex-Confederate General Alpheus Baker regarding Ulysses S. Grant when he said that "no man in the United States who, while he yet lived, could receive such a tribute."34 However, the only mention of Ulysses S. Grant, one year following the grand celebration of Grant's birth, pertained to the fact that he was dead.

${ }^{31}$ The Sixty-Third Birthday of Ulysses.S. Grant (Louisville, KY: 1885). Hereafter cited as SixtyThird Birthday.

${ }^{32}$ Cincinnati Commercial Gazette, 23 April 1885. 
Prior to the encampment of the Grand Army of the Republic in Louisville in 1895, the Courier-Journal, under the headline "They Died in Prison," told of the dedication of a Confederate memorial in Chicago, where nearly 6000 Confederate prisoners died in a Union prison camp, Camp Douglas, during the war. ${ }^{35}$ Three weeks later, the paper announced that the United Confederate Veterans Association had declared June third as Confederate Memorial Day. ${ }^{36}$ The year 1897 marked the dedication of Grant's Tomb in New York where a plaque commemorating Louisville's town meeting can be found. Yet, the Memorial History of Louisville, published in 1896, does not mention Grant's birthday celebration in Louisville. The Louisville Herald marked the one-hundredth birthday of Ulysses S. Grant by recalling Grant's visit in 1879 while ignoring Louisville's celebration of the dying president's sixty-third birthday. ${ }^{37}$ On May 1 , 1934 the Louisville Times, as part of its $50^{\text {th }}$ Anniversary issue, published an article that reflected on Louisville in the nineteenth century. It did not consider the event of April 27, 1885 worth a sentence, but did call the visit of President Chester A. Arthur to Louisville for the opening of the Southern Exposition "one of Louisville's big events of the eighties. ${ }^{138}$

Louisville continued its economic and population growth through the end of the nineteenth century, though it slowed in the twentieth century. While it is open to question whether or not the southern alliance strategy of Louisville's elites of

\footnotetext{
33 "The Confederate Chief," Courier-Journal, 28 April 1886: 1; "Davis Day," Courier-Journal 29 April 1886: 1.

34 Sixty-Third Birthday.

35 "They Died in Prison," Courier-Journal, 11 May 1895: 11.

36 "Memorial Day," Courier-Journal, 25 May 1895: 2.

37 "Grant's Visit Here Recalled," Louisville Herald, 27 April 1922.

${ }^{38}$ Times, I May 1934.
} 
the 1870's and 1880's proved successful in the long-term, it must be considered that those business leaders had died by the early twentieth century. Further, prior to the early nineteenth century, Louisville was considered as a western town. In relation to southern cities, Louisville shared more commonality with St. Louis, which had been in an antebellum slave state that sided with the Union in the Civil War. In spite of the geographic location, Louisville's leaders had worked to compete with northern cities for the southern markets. Men such as Henry Watterson used the ideological strength of the numerous ex-Confederates in Louisville's business community and melded it with the general economic interests of they city as a whole to form a united effot. Initially, the strategy proved successful. Yet, Louisville leaders did not envision the growth of southern cities, such as Atlanta, which usurped the economic allure and benefit of Louisville to southern markets. The long-term failure of Louisville to remain a strong economic allie of the South could rest in the geographic location of the city and the death of those who bet Louisville's future on an alliance with the South. Regardless of the conclusion drawn by analysts in determining the success or failure of Louisville's southern strategy in the 1870's and 1880's, Louisville's self-image as a southern city, born during that time, remained into the twenty-first century.

Though Louisville made a farewell gesture to the North with its celebration of U.S. Grant's birthday on April 27, 1885, the day also marked the end of any association Louisville had with the North. Recollection of the decade-long National Industrial Exposition is rare, but much has been written about the 
Southern Exposition that lasted but five years. Local history buffs and scholars have written about the monument to Confederate soldiers in Louisville in books and on modern websites; but no one has written about the memorial to Union soldiers in Louisville because none exists. April 27, 1885 marked the day that Louisville, Kentucky commemorated the birth of Ulysses S. Grant. It also marked the day that Louisville began to erase all vestige of association with the North. Books were not burned, museums ransacked or memorials torn down. The past was simply ignored. By 1950, the board of education in Louisville published a history of Louisville for junior high students, which referred to antebellum Louisville as part of the South. ${ }^{39}$ Children in Louisville of the twentieth century may have grown up in a southern city. Their parents and grandparents may have grown up in a southern city. But, until the August 1, 1883 opening of the Southern Exposition, Louisville was a child of the North.

${ }^{39}$ Lorena Eaton, Louisville in Kentucky (Louisville, KY: Louisville Public Schools, 1950), 14. 


\section{REFERENCES}

\section{Primary Sources}

Downs, G. F. Memorandum Book of G. F. Downs. Harding Collection. Filson Historical Society, Louisville, KY.

Location of Southern Exposition of Louisville. Louisville, KY, August 1883.

Kentucky History Collection. Louisville Free Public Library.

McCauley, Dan. Personal letter to Ulysses S. Grant. Miscellaneous Catalog. Filson Historical Society, Louisville, KY.

Parrish, Chuck. District Historian U. S. Army Corps of Engineers Louisville. Letter to Author. 12 February 2003.

Prather, Jr. Thomas Jacob. Letters to John Jeremiah Jacob, Jr., 1879-1880. John Jeremiah Jacob, Jr. 1861-Letters to Him From His Brother Thomas Prather Jacob, Jr. During His Trip to Europe 1879-1880. Filson Historical Society, Louisville, KY.

Rules and Regulations of the First Grand National Exposition of Arts, Invention, Manufactures and Products. Terrel Dietz \& Co. Printers. 1872.

The Sixty-Third Birthday of Ulysses S. Grant. Louisville, KY, 1885.

\section{Newspapers}

"Battle of Murfreesboro." Central Catholic Advocate 30 April 1885: 2.

“Beside Confederate Graves.” Courier-Journal 28 April 1885.

“A Cancer Cure." Courier-Journal 22 April 1885.

“The Confederate Chief." Courier-Journal 28 April 1885: 1.

“The Country at Large.” Courier-Journal 28 April 1885.

“Davis Day.” Courier-Journal 19 April 1886: 1. 
“The Day Elsewhere.” Courier-Journal 28 April 1885.

"The Day We Celebrate." Cincinnati Commercial Gazette 27 April 1885.

“The Death Watch on Grant.” Louisville Commercial 29 March 1885: 2.

“Decorated Graves.” Louisville Courier-Journal 31 July 1895: 1.

“Divided Opinion.” Louisville Courier-Journal 12 April 1885: 2.

"Dying." Louisville Post 31 March 1885: 1.

“The Exposition.” Louisville Courier-Journal 3 September 1872: 2.

“The Exposition.” Louisville Courier-Journal 5 September 1872.

"Ex-President Jefferson Davis." The Record 5 May 1885: 4.

"For Gen. Grant's Relief." Louisville Commercial 8 January 1885: 1.

"Gen. Grant." Louisville Times 1 April 1885: 1.

"General Grant." Louisville Times 2 April 1885: 1.

"Gen. Grant's Birthday." Louisville Courier-Journal 22 April 1885: 4.

"General Grant: Bulletins." Louisville Times 2 April 1885: 2.

“Gen. Grant's Disease." Louisville Commercial 19 April 1885: 1.

“Gen. Grant’s Relief.” Louisville Times 28 February 1885.

"General Not Know: Fred and Jesse Admit It's Fatal(or will be)." Louisville Courier-Journal 1 March 1885: 2.

“General Sherman's Proofs." Louisville Commercial 12 January 1885: 1.

“Going to Secede." Louisville Courier-Journal 25 April 1885: 5.

“Grant.” Louisville Daily Commercial 11 December 1879.

"Grant Fund Raised." Louisville Post 1 January 1885: 1.

"The Grant Memorials." Louisville Daily_Commercial 12 January 1885: 1.

"Grant Worse." Louisville Post 30 March 1885: 1. 
"Grant's Oratory and Greely's Wisdom." Louisville Courier-Journal 28 September 1872: 2.

“Grant's Speeches.” Louisville Courier-Journal 30 September 1872: 2.

“Grant's Visit Here Recalled.” Louisville Herald 27 April 1923.

“A Great Event.” Louisville Courier-Journal 4 September 1872.

“He Takes a Stroll.” Louisville Evening Post 22 April 1885.

"How Kentucky's Chief City Honored General Grant." The Record 15 December 1879: 8 .

“An Idiotic Gabbler.” Louisville Courier-Journal 16 August 1871, Weekly ed.

"Is Grant Dead." Louisville Daily Commercial 28 February 1885: 1.

"Jefferson Davis: The Reports of His Demise Greatly Exaggerated." Louisville Daily Commercial 2 April 1885.

“Jefferson Davis To Grant.” Louisville Daily Commercial 6 April 1885.

“Kind Words For Gen. Grant.” Louisville Times 28 April 1885: 4.

“A Leaf From Grant's Record Book." Louisville Courier-Journal 1 October 1872: 2.

"The Louisville Exposition." Washington Post 8 June 1883: 1.

“Mark Twain On Babies.” Central Catholic Advocate 18 December 1879: 3.

"Memorial Day." Louisville Courier-Journal 25 May 1895: 2.

“A Monument Built By Years of Womanly Devotion.” Louisville Times 16 December 1954.

"Must Die: No Hope of General Grant's Recovery." Louisville Evening Post 25 April 1885.

“The National Exposition.” Louisville Courier-Journal 21 October 1882: 4.

“A Nation’s Dying Hero.” Louisville Daily Commercial 2 April 1885.

"Not So Well." Louisville Courier-Journal 13 April 1885: 1. 
"Old Reporter's Recollection of the Dying Soldier." Louisville Courier-Journal 27 March 1885: 8.

“Organizing Success." Louisville Courier-Journal 21 October 1882: 4.

“Our Cotton Exposition.” Louisville Courier-Journal 24 October 1872: 4.

“Our New Southern Line.” Louisville Courier-Journal 27 September 1872: 1.

“Our Southern Guests." Louisville Courier-Journal 9 October 1872.

“Our Welcome.” Louisville Courier-Journal 10 October 1872.

"Put In Place.” Louisville Courier-Journal 26 May 1895: 4.

“The Re-electionists." Louisville Courier-Journal 28 September 1872: 2.

“The Republican Stripe." Central Catholic Advocate 18 December 1879: 4.

“Sears Secret Hated.” Louisville Daily Commercial 29 March 1885: 1.

“Six Men Killed.” Louisville Daily Commercial 8 January 1885: 1.

"The Southern Phase of the Grant Boom." Central Catholic Advocate 4 December 1879: 4.

“They Died in Prison.” Louisville Courier-Journal 11 May 1895: 2.

“A Tough Old Soldier.” Louisville Times 15 April 1885: 1.

“Truly Phenomenal.” Louisville Times 17 April 1885: 1.

“Unchanged." Louisville Courier-Journal 5 April 1885: 2.

“A Very Sick Man." Louisville Post 28 February 1885: 1.

"Well Met." Louisville Courier-Journal 11 December 1879.

Industrial News August 1883. Filson Historical Society Collection.

Cincinnati Commercial Gazette 23 April 1885.

Louisville Courier-Journal 5 September 1872: 4.

Louisville Courier-Journal 7 September 1872: 1. 
Louisville Courier-Journal 1 October 1872.

Louisville Courier-Journal 4 October 1872: 4.

Louisville Courier-Journal 19 October 1872.

Louisville Courier-Journal 22 October 1872: 5.

Louisville Courier-Journal 10 September 1895: 1.

Louisville Times 20 April 1885: 2.

Louisville Times 1 May 1934.

Master's Theses

Cornell, Charlene M. Louisville in Transition: 1870-1890. Master's Thesis. University of Louisville, 1970.

Marshall, Anne Elizabeth. Louisville and The Lost Cause: Memory; IndentityThe Creation of a Confederate City. Master's Thesis. University of Georgia, 2000.

Wright, Leslie S. The Louisville and Portland Canal. Master's Thesis. University of Louisville, 1939.

\section{Journal Articles}

Cole, Jennifer. "For the Sake of the Songs of the Men Made Free: James Speed and the Emancipationists' Dilemma in Nineteenth-century Kentucky." Ohio Valley History 4 (Winter 2004)

Young, Amy L. and J. Blaine Hudson. "Slave Life at Oxmoor" The Filson Historical Quarterly 74 (Summer 2000)

\section{Government Publications}

United States. Ninth Census of the United States: Statistics of Population Vol. I. Washington, D. C.: Government Printing Office, 1872.

Tenth Census of the United States 1880 Part II: The Southern and Western States Washington, D. C. : Government Printing Office, 1887.

\section{Anthologies and Reference Works}

Atwater, Caleb. "Remarks Made on a Tour of Prairie du Chien" (1831) 
Louisville Library Collection Series: Collected Writings Relating to the History of Louisville. Vol. I. Louisville, KY: Louisville Free Public Library, 1935 .

Butler, Mann. "A History of the Commonwealth of Kentucky." (1834) Louisville Library Collection Series: Collected Writings Relating to the History of Louisville. Vol. I. Louisville, KY: Louisville Free Public Library, 1935.

Cooper, Thomas. "Letters From America to a Friend in England." (1794) Louisville Library Collection Series: Collected Writings Relating to the History of Louisville. Vol. I. Louisville, KY: Louisville Free Public Library, 1935.

Durret, Reuben T. "The Centenary of Kentucky Filson Club Proceedings." (1892) Louisville Library Collection Series: Collected Writings Relating to the History of Louisville. Vol. I. Louisville, KY: Louisville Free Public Library, 1935.

Fearon, Henry Bradshaw. "Sketches of America-A Narrative of a Journey Through the Eastern and Western States of America." (1818) Louisville Library Collection Series: Collected Writings Relating to the History of Louisville. Vol. I. Louisville, KY: Louisville Free Public Library, 1935.

History of the Ohio Falls Cities and Their Counties. Vol. I. Cleveland: L.A. Williams \& Company, 1882.

Johnston, J. Stoddard, ed. Memorial History of Louisville From Its First Settlement To The Year 1896. Vol. I. Chicago: American Biographical Publishing Company, 1896.

Kleber, John E. ed. Encyclopedia of Louisville. Lexington, KY: University Press of Kentucky, 2001.

Melish, John. "Travels in the United States of America." Louisville Library Collection Series: Collected Writings Relating to the History of Louisville. Vol. I. Louisville, KY: Louisville Free Public Library, 1935.

Michaux, F. A. "Travels to the Westward of the Allegany Mountains in the States of Ohio, Kentucky, and Tennessee." (1805) ." Louisville Library Collection Series: Collected Writings Relating to the History of Louisville. Vol. I. Louisville, KY: Louisville Free Public Library, 1935.

\section{Monographs}

Blight, David W. Race and Reunion: The Civil War in American Memory. Cambridge, MA: Belknap Press, 2000. 
Briney, Melvin O. Fond Recollections: Sketches of Old Louisville. Louisville, KY: Louisville Times, 1955.

Chernow, Ron. Titan: The Life of John D. Rockefeller, Jr. New York: Random House, 1998.

Cooper, William J., Jr. Jefferson Davis: American. New York: Vintage Books, 2001

Curry, Leonard P. Rail Routes South: Louisville's Fight for the Southern Market, 1865-1872. Lexington, KY: University of Kentucky Press, 1969.

Eaton, Lorena. Louisville In Kentucky. Louisville, KY: Louisville Public Schools, 1950.

Foner, Eric. Reconstruction: America's Unfinished Business 1863-1877. New York: Harper and Row, 1989.

Frazier, E. Franklin. The Negro in the United States. New York: MacMillan Co., 1949.

Grant, Ulysses S. The Personal Memoirs of Ulysses S. Grant. New York: Smithmark, 1994.

Hall, Wade, and Nancy Jones. Louisville 200: Reflections of a City. Louisville, KY: Hamilton Printing Co., 1978.

Herr, Kincaid. The Louisville and Nashville Railroad: 1850-1863. Lexington, KY: University of Kentucky Press, 1964.

Kramer, Carl E. Visionaries, Adventurers, and Builders: Historical Highlights of the Falls of the Ohio. Jeffersonville, IN: Sunnyside Press, 1999.

McDonough, James Lee. War in Kentucky: From Shiloh to Perryville. Knoxville, TN: University of Tennessee Press, 1994.

McDowell, Robert Emmett. City of Conflict: Louisville in the Civil War, 18611865. Louisville, KY: Louisville Civil War Roundtable, 1962.

McFeely, William S. Frederick Douglass. New York: W.W. Norton, 1995.

McFeely, William S. Grant: A Biography. New York: W.W. Norton, 1982.

Munro-Leighton, Judy. Changes at the Falls. Louisville, KY: Portland Museum, 1982. 
Reibel, R. C. Louisville Panorama: A Visual History of Louisville. $2^{\text {nd }} \mathrm{ed}$.

Louisville, KY: Liberty National Bank and Trust Company, 1956.

Reid, Robert. Always a River: The Ohio River and the American Experience. Bloomington, IN: Indiana University Press, 1991.

Smart, James G. A Radical View: The "Agate" Dispatches of Whitelaw Reid 1861-1865. Vol. 1. Memphis, TN: Memphis State University Press, 1976.

Tapp, Hambleton and James C. Klotter. Kentucky: Decades of Discord 18651900. Frankfort, KY: The Kentucky Historical Society, 1977.

Wall, Frazier. Henry Watterson: Reconstructed Rebel. New York: Oxford University Press, 1956.

Watterson, Henry. Marse Henry: An Autobiography. Vol. 1. New York: Beekman Publishers, 1974.

Wood, F.E. The Louisville Story: A Report of the Sinking Fund Commission. Louisville, KY: City of Louisville, 1951.

Yater, George H. Two Hundred Years at the Falls of the Ohio: A History of Louisville and Jefferson County. $2^{\text {nd }} \mathrm{ed}$. Louisville: The Filson Club, 1987. 


\section{CURRICULUM VITAE}

NAME: $\quad$ Robert Bruce Symon, Jr.

ADDRESS: Meteorology Department

WLKY-TV

1918 Mellwood Ave.

Louisville, KY 40206

DOB: $\quad$ New Orleans, Louisiana-April 16, 1962

EDUCATION:

M.A., History

University of Louisville, Louisville, KY

May 2005

B.S., Meteorology

Minor-Physics

Florida State University, Tallahassee, FL

April 1991

Bachelor of Journalism

University of Texas, Austin, TX

May 1984

AWARDS:

Associated Press of Louisiana

Best Weathercast Division

Associated Press of Mississippi

Best Weathercast Division

PROFESSIONAL AND ACADEMIC SOCIETIES:

American Meteorological Society

National Weather Association

Filson Historical Society

Phi Alpha Theta

Sigma Phi Epsilon 


\title{
PROFESSIONAL LICENSES AND AFFILIATIONS:
}

American Meteorological Society Broadcast Seal National Weather Association Broadcast Seal New York Stock Exchange, 1985-1988

NASDAQ, 1985-1988

Series 7, 1985-1988

Series 6, 1985-1988

Texas Board of Realtors, 1985-1988

Texas Board of Life Insurance, 1985-1988

\section{ACADEMIC WORK EXPERIENCE:}

\author{
Instructor \\ University of Southwest Louisiana, Lafayette, LA \\ Continuing Education \\ 1994-1995 \\ Instructor \\ University of Louisville, Louisville, KY \\ Continuing Education \\ 1998-1999
}

\section{WORK EXPERIENCE:}

Meteorologist, WLKY-TV

Louisville, KY 1998-2005

Chief Meteorologist, WXVT-TV,

Greenville, MS 1997-1998

Meteorologist, WBMA-TV

Birmingham, AL 1996

Meteorologist, KLFY-TV

Lafayette, LA 1993-1996

Chief Meteorologist, KLAX-TV

Alexandria, LA 1991-1993

Chief Meteorologist, WTWC-TV

Tallahassee, FL 1988-1991

Account Executive, WTRG-FM

Raleigh, NC 1988 
Account Executive, KHLB-AM/FM

Marble Falls, TX 1987

Financial Consultant, Merrill Lynch, Pierce Fenner \& Smith, Houston, TX 1985-1987

Airborne Traffic Reporter, Metro Traffic Control, Houston, TX 1984

\section{COMMUNITY SERVICE AND PRESENTATIONS:}

Cabbage Patch Settlement House

Louisville, KY

Presbyterian Center

Presbyterian Church (USA)

Louisville, KY

Jefferson County School District

Jefferson County, KY

Washington County School District

Washington County, MS

Lafayette Parish School District

Lafayette Parish, LA

Leon County School District

Leon County, FL

Lafayette General Hospital

Lafayette, LA 